\title{
Factors associated with attitudes toward U.S. immigration, 2004-2016
}

\author{
Ernesto F. L. Amaral \\ Texas A\&M University \\ amaral@tamu.edu \\ Paige Mitchell \\ Texas A\&M University \\ paigemitchell396@gmail.com \\ Guadalupe Marquez-Velarde \\ Utah State University \\ guadalupe.marquez-velarde@usu.edu
}

\begin{abstract}
This paper investigates demographic, socioeconomic, political, and contextual factors associated with attitudes toward U.S. immigration. Our innovative study integrates data from the General Social Survey and American Community Survey between 2004-2016. The models include individual-level and county-level variables. We estimate generalized ordered logit models that allow for a better understanding of associations between immigration attitudes and independent variables. We explore disaggregated categories of several independent variables. Results suggest that support to immigration has been increasing over time. Overall, results are suggestive of a race and social class divide in terms of attitudes towards immigration. Non-whites, people with lower levels of racial resentment, those with higher educational attainment, and people who live in counties with higher proportions of college graduates are more likely to be pro-immigration. In contrast, people at the lower end of the occupational stratum, such as those working in areas related to natural resources, construction, maintenance, production, transportation, moving services, and the military are less likely to support immigration. In addition, those between 18 and 24 years of age, non-Protestants, people not living in the South Atlantic region, and those with liberal political inclinations are more likely to be pro-immigration. Finally, our findings also suggest that exposure to immigrants might shape attitudes towards this issue. For example, people who at 16 years of age lived in areas that tend to have higher proportions of foreign-born individuals and those living in counties with higher proportions of immigrants are more likely to support immigration.
\end{abstract}

\section{Keywords}

Immigration attitude. Demographic factors. Socioeconomic factors. Political factors. Contextual factors.

\section{Citation}

Amaral EFL, Mitchell P, Marquez-Velarde G. 2019. "Factors associated with attitudes toward U.S. immigration, 2004-2016.” Open Science Framework Preprints, February 22. (http://doi.org/10.31219/osf.io/nkry6) 


\section{Introduction}

This paper aims to investigate current individual and contextual characteristics related to attitudes toward immigration in the United States. This research topic has gained prominence in the public sphere due to the 2016 U.S. presidential election. One of the main platforms used by the current president's campaign, as well as throughout his presidency, is the implementation of a new immigration system. The main propositions include policies to increase security at the Southern border, restrain family reunification (process by which permanent residents sponsor family members for immigration), eliminate the Diversity Immigrant Visa Program (also known as the green card lottery), establish criteria to provide immigrant visas based on skills and educational attainment (referred to as a merit-based entry system), and increase the deportation of undocumented immigrants (through actions of the U.S. Immigration and Customs Enforcement - ICE). All these proposed or ongoing policies are intrinsically related to opinions about the number of immigrants in the country.

Several studies have explored attitudes toward immigration in the United States. As a result, a series of theories to explain opinions about immigration using quantitative and qualitative approaches have been developed. Our analysis contributes to this literature by providing an innovative approach to investigate this topic. First, our models integrate data from the General Social Survey (GSS) and the American Community Survey (ACS) from 2004 to 2016, a timeframe that encompasses the social context of the last U.S. presidential election. Second, we estimate multivariate models that include individual-level and contextual-level factors associated with attitude toward immigration. This study incorporates several variables to test different theoretical frameworks that were previously pointed to as possible explanations for opinions about immigration. We include county-level variables that control for demographic and 
socioeconomic characteristics of American locations. We analyze cross-sectional cumulative data from GSS to generate individual-level variables, as well as GSS Sensitive Data Files and ACS five-year estimates to generate county-level variables. Third, the estimated generalized ordered logit models are more informative and better capture associations between the ordinal variable about immigration attitude with several independent variables, compared to logistic regressions, ordinal regressions, or multinomial logistic regressions. Fourth, we enhance previous estimations by exploring disaggregated categories on race/ethnicity, age group, education degree, religion, occupation, region of interview, area of residence at age 16, political party affiliation, political views, racial resentment, and opinion about U.S. economic achievement.

The following section provides an overview of previous studies that dealt with individual and contextual factors associated with attitudes toward immigration. In the subsequent section, we present details about employed methods, investigated databases, and selected variables. Then we provide results from bivariate analyzes and multivariate regression models. We end this paper with final considerations that summarize our results and provide insights for future studies.

\section{Background}

Immigration policy is a highly contested matter of public opinion. The proposal to build a wall along the US-Mexico border is currently driving the immigration public debate. However, a wide array of federal, state, and local policies centered on immigration have kept the matter salient since the 1990s (Chandler and Tsai 2001). In this section, we summarize individual and contextual factors that were highlighted by previous studies as associated with attitudes toward immigration. 
Analyzes about attitudes toward immigration suggest that age is positively related to antilegal immigration attitudes (Chandler and Tsai 2001). Older respondents are more likely to want to decrease the number of legal immigrants. In terms of gender, females are more anti-legal immigration than males, but this relationship is not statistically significant for anti-illegal immigration. Overall, age and sex have not been found to be consistent nor significant predictors of attitudes toward immigrants (Chandler and Tsai 2001, Espenshade and Hempstead 1996, Fetzer 2000). Another study suggests that the millennial generation, those born from the early 1980s to the 2000s, have more positive views toward immigration than non-millennials, based on the 2008 American National Election Study (ANES) (Ross and Rouse 2015).

The formation of social identities is strongly related to attitudes toward immigrants and immigration policy (Fussell 2014, Stets and Burke 2000). White immigrants and non-White immigrants are more likely to have favorable perceptions of immigrants, compared to White natives (Haubert and Fussell 2006). Individuals mentally categorize themselves and others into "in-groups" and "out-groups," which has important implications in the development of immigration-related attitudes (Fussell 2014). Both the non-Hispanic White majority and minority groups could engage in group consciousness often resulting in divergent attitudes toward immigrants. For instance, Latinos, both foreign and native born, tend to be pro-immigrant and are more prone to engage in political activism with increasing levels of group consciousness (Sanchez 2006, 2008). At the opposite end of the spectrum, group consciousness among nonminorities might result in negative attitudes toward other groups, who might be perceived as challenging or jeopardizing non-minority standing in society, regardless of the authenticity of these claims (Berg 2015). People tend to dismiss negative thoughts about minority groups through interaction (Cote and Erickson 2009, Hood III and Morris 1997, McLaren 2003). A 
majority group member who lives in an area with many immigrants typically holds a positive attitude toward immigration (Dixon 2006). People with positive attitudes toward immigration are typically wealthier and have more experiences with minority groups (Haubert, Fussell 2006).

Level of education is one of the most important and consistent predictors of immigrant attitudes. Individuals with higher levels of education tend to be more pro-immigrant than individuals with lower educational status (Berg 2010, Berg 2015, Burns and Gimpel 2000, Chandler and Tsai 2001, Espenshade 1995, Haubert and Fussell 2006, Hood III and Morris 1997). Since most studies of the effect of educational level on immigration attitudes are crosssectional, there is a scholarly debate on whether education actually makes individuals proimmigrant or only teaches them to support a pro-immigrant ideology (Jackman and Muha 1984, Janus 2010). Studies also suggest that people who live in areas that are predominantly occupied by college graduates have higher individual levels of tolerance (Bobo and Licari 1989, Moore and Ovadia 2006).

Prominent religious figures and leaders are constantly affecting the beliefs of followers in the congregation (Moore and Ovadia 2006). Areas with higher proportions of evangelical Protestants decrease individual levels of tolerance. This trend is spread throughout areas with a large number of evangelical Protestants, which are largely seen in the South due to conservative teachings and tendencies (Ellison and Musick 1993, Moore and Ovadia 2006).

An individual's belief that immigrants affect their job status and/or standard of living is defined as the labor market competition hypothesis (Espenshade 1995). This negative view is especially expressed by people of lower socioeconomic status (Burns and Gimpel 2000, Espenshade 1995, Espenshade and Hempstead 1996). When the majority race believes that minorities are purposely taking advantage of society resources, anti-minority attitudes increase 
(Blalock 1970). More specifically, occupation significantly predicted negative perceptions of immigrants (Haubert and Fussell 2006). Blue-collar and service workers are more likely to hold negative perceptions, because immigrants are perceived as competitors in the labor market for low-skilled jobs. In the United States, economic development is continuously affecting residents' attitudes toward immigrants. When immigrants have improvements in labor market outcomes, non-immigrants tend to increase negative opinions toward immigrant tolerance (Esses and Dovidio 2011).

Individual's political and stereotypical beliefs play an important role in the development of immigration attitudes (Berg 2015). Conservatives tend to hold more negative views toward immigration than liberals (Chandler and Tsai 2001, Haubert and Fussell 2006). However, the relationship between political partisanship and attitudes toward immigrants is not always straightforward (Neiman, Johnson, and Bowler 2006). In California, Republicans are more likely to think that immigration has deleterious effects on social and policy outcomes, but Democrats shared the same concerns.

A recent study found that attitudes toward immigration have stronger correlations with racial resentment than economic anxiety (Miller 2018). More specifically, using items about racial resentment from ANES, estimates indicate that those with negative opinions toward black people tend to have anti-immigration attitudes. Racial resentment of white people toward black people is not necessarily related to an anti-immigration opinion, since only around nine percent of African Americans are immigrants. Thus opinion about black people is related to a broader perspective of white people toward various minorities (Miller 2018). We now present our research strategy to estimate associations of these several factors with attitudes toward immigration. 


\section{Methods}

\subsection{Data and dependent variable}

We analyzed cross-sectional cumulative data from the 2004-2016 GSS. This survey has data representative to the adult population in the United States and allows us to investigate attitudes toward immigration. We also utilize data from the GSS Sensitive Data Files, which include information on state, county, and census tract of residence for each individual. These sensitive variables allow us to generate county-level variables with GSS. We are also able to merge individual-level GSS data into county-level variables generated with the 2006-2010, 2008-2012, 2010-2014, and 2012-2016 ACS five-year estimates, as explained in following subsections. We considered the GSS complex sample design for all estimates reported in this study. For this paper, we concentrated the analysis on a dependent variable that indicates the opinion of respondents about how should the number of immigrants to American be nowadays, which is available for $1996,2004,2008,2010,2012,2014$, and 2016. We organized this variable in a manner that higher values indicate a more positive view toward immigration, so we refer to this variable as a pro-immigration scale. This variable gives the following alternatives: (1) reduced a lot; (2) reduced a little; (3) remain the same as it is; (4) increased a little; and (5) increased a lot. We investigate only data starting in 2004, because information on Hispanic origin is available since 2000 , which is used to compose one of our independent variables. We keep only observations with valid information (non-missing cases) for all GSS variables utilized in this study, which resulted in an overall sample size of 9,265 respondents. The sample size by year and opinion about how should the number of immigrants to America be nowadays is reported on Table 1. These numbers are smaller for models that include independent variables 
related to political views, racial resentment, and opinion about U.S. economic achievement, because these questions were implemented to fewer respondents.

\section{>> Table $1 \ll<$}

Our models are controlled for a series of individual-level and county-level independent variables. As the dependent variable, the individual-level variables come from the 2004-2016 GSS. The county-level independent variables are generated from GSS and from a series of ACS five-year estimates. We explain each set of independent variables in the following sub-sections.

\subsection{Individual-level independent variables}

Following strategies of previous studies, we controlled the models for a series of independent variables at the individual level from GSS: year (2004, 2008, 2010, 2012, 2014, 2016); sex (female, male); race/ethnicity (non-Hispanic White, non-Hispanic Black, Hispanic, other); age group (18-24, 25-44, 45-64, 65-89); education degree; religion; occupation; region of interview; area of residence at age 16; political party affiliation; political views; racial resentment; and economic anxiety.

Information on education degree has the following categories: (1) less than high school; (2) high school; (3) junior college; (4) bachelor; and (5) graduate. The intention was to control the models for this disaggregated variable to better understand variations in attitudes toward immigration by level of education, going beyond binary information on whether the respondent completed college.

Religion of respondent was analyzed using the following categories: (1) Protestant; (2)

Catholic; (3) Christian; (4) Jewish; (5) other religions; and (6) none. We intended to capture differentials in attitudes toward immigration between Protestants and Catholics. As a result, we 
did not group Christians with any of these two religions, because we do not have information on their specific religion based on GSS data.

Occupations were aggregated according to the 2010 Census Occupation Codes: ${ }^{1}$ (1) management, business, science, and arts occupations; (2) service occupations; (3) sales and office occupations; (4) natural resources, construction, and maintenance occupations; (5) production, transportation, and material moving occupations; (6) military specific occupations; (7) unspecified occupations; and (8) unemployed. An issue with this independent variable is that it aggregates people with diverse occupations in the same categories. However, the original disaggregated variable would produce coefficients even less informative, because the 2010 Census occupation classification list has 539 codes.

Our models also control for possible unobserved regional factors associated with attitudes toward immigration. More specifically, we add information on region of interview, which gives information on residence of individual: (1) New England (Maine, Vermont, New Hampshire, Massachusetts, Connecticut, Rhode Island); (2) Middle Atlantic (New York, New Jersey, Pennsylvania); (3) East North Central (Wisconsin, Illinois, Indiana, Michigan, Ohio); (4) West North Central (Minnesota, Iowa, Missouri, North Dakota, South Dakota, Nebraska, Kansas); (5) South Atlantic (Delaware, Maryland, West Virginia, Virginia, North Carolina, South Carolina, Georgia, Florida, District of Columbia); (6) East South Central (Kentucky, Tennessee, Alabama, Mississippi); (7) West South Central (Arkansas, Oklahoma, Louisiana, Texas); (8) Mountain (Montana, Idaho, Wyoming, Nevada, Utah, Colorado, Arizona, New Mexico); and (9) Pacific (Washington, Oregon, California, Alaska, Hawaii).

\footnotetext{
${ }^{1}$ https://www.census.gov/people/io/files/2010_OccCodeswithCrosswalkfrom2002-2011nov04.xls
} 
We also controlled our models by area of residence at age 16, based on information about region of residence at age 16 and type of place lived at age 16 . Our intention is to test whether respondents who lived in areas in which they had higher chances to interact with foreign-born individuals (in foreign countries and big American cities) have more positive attitudes toward immigration than respondents who were less exposed to foreign-born individuals (in smaller American cities). Region of residence at age 16 gives information on place each individual lived: (1) New England; (2) Middle Atlantic; (3) East North Central; (4) West North Central; (5) South Atlantic; (6) East South Central; (7) West South Central; (8) Mountain; (9) Pacific; and (10) foreign country. Type of place lived at age 16 informs whether individual resided in: (1) country/non-farm; (2) farm; (3) town with less than 50,000 inhabitants; (4) city between 50,000 and 250,000 inhabitants; (5) big-city suburb; and (6) city with more than 250,000 inhabitants. The final variable has the following categories: (1) Foreign country; (2) country/non-farm; (3) farm; (4) town with less than 50,000 inhabitants; (5) city between 50,000 and 250,000 inhabitants; (6) big-city suburb; and (7) city with more than 250,000 inhabitants.

We take advantage of the detailed information about political party affiliation, available in GSS: (1) strong Democrat; (2) Democrat; (3) Independent near Democrats; (4) Independent; (5) Independent near Republicans; (6) Republican; (7) strong Republican; and (8) other party. Previous studies usually aggregate party identification into Democrats, Independents, and Republicans. Our intention was to take advantage of all the full scale of party affiliation, instead of aggregating categories, in order to verify different associations with attitudes toward immigration. Another variable related to ideological background asks respondents where they place themselves on a seven-point scale related to political views. We also estimated models that controlled for this variable, which has the following categories: (1) extremely liberal; (2) liberal; 
(3) slightly liberal; (4) moderate; (5) slightly conservative; (6) conservative; and (7) extremely conservative.

We include variables to control for racial resentment with the hypothesis that it would be an accurate measure of understanding anti-immigrant attitudes in the United States. As a strategy to control our models for racial resentment, we used the following two proxies from GSS: (1) Are we spending too much, too little, or about the right amount on improving the conditions of Blacks; (2) Are we spending too much, too little, or about the right amount on assistance to Blacks. These two variables were asked to different subgroups of the GSS sample. As a result, we combined these two questions in one variable that measures racial resentment on a Likert scale: (1) low; (2) medium; and (3) high.

Finally, we aimed to control our models for a measure of economic anxiety. In our models, we included a variable that informs how proud are respondents of U.S. economic achievements: (1) very proud; (2) somewhat proud; (3) not very proud; and (4) not proud at all. Among the years analyzed in this paper, this variable is available only for 2004 and 2014.

\subsection{County-level independent variables}

Our models are estimated by controlling for a series of contextual independent variables, following findings from previous studies that these characteristics are associated with attitudes toward immigration. We first use the GSS Sensitive Data Files to add variables about state and county of residence for each individual in each year. Then, we estimate a series of county-level variables based on GSS, which allow us to control our models by county-level characteristics in each year that are relevant to our study: (1) proportion of unemployment; (2) proportion of college graduates; and (3) proportion of Protestants and Catholics (combined). 
We also select variables at the county level from the 2006-2010, 2008-2012, 2010-2014, 2012-2016 ACS five-year estimates, available in the National Historical Geographic Information System (NHGIS) database (Manson et al. 2018). We calculate the proportion of immigrants, based on estimates about the number of natives and foreign-born population in each county and time period. Since one-year estimates are not available and we are interested in a historical time series, we merge each of these ACS five-year estimates from NHGIS to our GSS data, considering their middle year: 2008, 2010, 2012, and 2014, respectively. We highlight that these ACS five-year estimates are not the result for any single year and they are not exactly an average of one-year estimates (Beaghen and Weidman 2008). These five-year estimates are close to the average of the one-year estimates within each period.

\subsection{Models}

First, we estimated a null hierarchical model to evaluate the amount of variability between counties. We indicated the individual-level dependent variable (opinion about immigration) and the county as the second level of aggregation. We estimated that county random effects compose approximately 5.8 percent of the total residual variance, based on the intra-class correlation coefficient. This percentage indicates a low variability between counties, so there is no need to estimate a hierarchical model to introduce county-level variables in our regression models.

Then, we estimated a series of generalized ordered logit models, which are appropriate for dependent variables at the ordinal level of measurement. Our models test the association of several independent variables with the opinion about the number of immigrants in the country (dependent variable). We used the "gologit2" command in Stata with the "autofit" option (Long 
and Freese 2014, Williams 2016). This strategy automatically identifies whether coefficients for each category of each independent variable are the same or different across the categories of the dependent variable.

The odds ratios indicate the factor change in odds of observing a value above the listed category versus observing values at or below the listed category. We label these odds ratios as: (1) "above reduced a lot," which relates to odds ratios of individuals being above "reduced a lot" versus being at "reduced a lot;" (2) "above reduced a little," which refers to odds ratios of individuals being above "reduced a little" versus being at "reduced a little" or below; (3) "above remain the same," which refers to odds ratios of individuals being above "remain the same" versus being at "remain the same" or below; and (4) "above increased a little," which refers to odds ratios of individuals being above "increased a little" versus being at "increased a little" or below.

For regression estimates with county-level variables, we specified standard errors that allow for intragroup correlation within counties (fipscnty variable) with "vce(cluster fipscnty)" option. The "vce" option does not allow the indication of the complex survey design in the same estimation. As a robustness check, we estimated these models with county-level variables without the "vce" option and with the complex survey design. Results were similar between these estimation procedures.

\section{Bivariate results}

In relation to the opinion of the adult population in the United States about the number of immigrants in the country, those who want to reduce immigration declined between 2004 and 2016. However, those who want to reduce immigration remain a higher percentage of the 
population, 42.31 percent in 2016 (reduce a lot and reduce a little), compared to those who want to increase immigration, 17.73 percent in 2016 (increase a lot and increase a little). The percentage of anti-immigration respondents is also higher than those who want the number of immigrants to remain the same, 39.96 percent in 2016.

Going into more details in the scale about opinion on number of immigrants, those who think immigration should be reduced a lot changed from 26.42 percent in 2004 to 19.26 percent in 2016 (Figure 1). The share of those who think immigration should be reduced a little dropped from 28.21 percent to 23.05 percent in the same period. The percent of those who think immigration should remain the same increased from 35.28 to 39.96 percent between 2004 and 2016. Finally, those who are in favor of increasing immigration a little rose from 6.56 to 11.79 percent, and those in favor of increasing immigration a lot rose from 3.52 to 5.94 percent in the period.

\section{>> Figure $1<<<$}

Table 2 provides information on bivariate associations between opinion about immigration and several independent variables. Information is presented only for 2016 as a way to summarize these associations. Women and men do not seem to differ on their opinion about immigration. These distributions do indicate that men tend to have higher percentages on the extremes of the pro-immigration scale, while women have higher percentages in the remain the same category. Non-Hispanic whites have higher percentages in the reduced a lot category than other race/ethnicity groups. Hispanics and people of other races/ethnicities tend to be more proimmigration than other groups.

>> Table $2<<<$ 
In terms of age, younger people seem to be more pro-immigration (Table 2). More educated people tend to be more in favor of increases in the number of immigrants than less educated people. One exception is noted when more than 10 percent of people with less than high school reported being in favor of increasing a lot the number of immigrants, which is the highest percentage across all educational groups. In terms of religion, Protestants tend to have the highest percentages in favor of reducing immigration, compared to other religions.

The occupation variable indicates that people in management, business, science, and arts tend to have smaller percentages in the reduced a lot category than other occupations (Table 2). People in sales, office, natural resources, construction, and maintenance occupations have the smallest percentages in the combined pro-immigration categories (increased a little and increased a lot). We do not include unspecified occupations in this group, because they have a small sample size. People in military occupations have the highest percentages in the increased a little category and increased a lot category, but there are only ten respondents in these occupations.

Concerning region of interview, people in East North Central, West North Central, South Atlantic, East South Central, and West South Central tend to be more in favor of a decrease in immigration (Table 2). In these regions, at least 45 percent of respondents are in the combined group of reduced a lot and reduced a little. People in New England, East South Central, Mountain, and Pacific regions tend to be more pro-immigration than people in other regions. At least 21 percent of residents in these regions are in the combined group of increased a little and increased a lot. Notice that East South Central was referred in both anti-immigration and proimmigration groups, as a result of their low percentage in the remain the same category.

In relation to area of residence at age 16 , those who resided in a foreign country are more likely to be pro-immigration than residents in other areas (Table 2). This group might have 
foreign-born individuals who were residing in the United States at the time of the interview, who tend to be more pro-immigration. However, we do not have information on place of birth in the GSS database. People living in areas with less inhabitants (country, non-farm; farm; and town with less than 50,000 people) are more likely to want to decrease immigration a lot than people living in other areas. In cities with more than 250,000 inhabitants, pro-immigration categories (increased a little and increased a lot) have almost the same levels as people who lived in foreign countries. This could be related to big cities having more immigrants, which might influence positive perceptions toward an increase in immigration.

One of the main independent variables we include in our models is political party affiliation. Figure 2 provides some insights about associations between attitudes toward immigration and political party affiliation through time. Overall, strong Democrats and Democrats have been more in favor of immigration remaining at the same level, increasing a little, or increasing a lot in recent years, compared to 2004. The highest percentage point increases were observed among those who think immigration should remain the same between 2004 and 2016: 12.8 percentage point increase among strong Democrats and 12.3 among Democrats. Among these Democratic groups, those who think immigration should be reduced a little or reduced a lot dropped over time. More specifically, there was 14.3 percentage point decrease in the reduced a lot category for both strong Democrats and Democrats in the period. The same patterns are observed among Independents. However, this group had smaller decreases in the categories related to reduce immigration, as well as smaller increases in the categories of immigration remain the same and increased a little than the two Democratic groups.

>> Figure $2<<<$ 
Both Republicans and strong Republicans have low levels of being in favor of an increase in immigration (Figure 2). Moreover, opinion about number of immigrants oscillated through time among Republicans, but percentages did not change significantly between 2004 and 2016. The sharpest change was a drop of 1.6 percentage points in the reduced a lot category. Among strong Republicans, those who think that immigration should be reduced a lot rose 4.6 percentage points: from 30.10 to 34.66 percent between 2004 and 2016 . Those in favor of immigration increasing a little had a percentage point increase of 5.0 among strong Republicans, but the overall levels were small: 2.52 percent in 2004 and 7.54 percent in 2016. Strong Republicans in favor of immigration numbers remaining the same reduced from 30.96 percent in 2004 to 25.75 percent in 2016.

Table 3 illustrates associations of immigration opinion with political views, racial resentment, and opinion about U.S. economic achievement. Each of these independent variables have a smaller sample size than the previous independent variables. Our intention now is to estimate models that explore the association of political ideology with our dependent variable, going beyond the political party classification. Moreover, we aim to understand correlations of the dependent variable with racial resentment and opinion about economic achievement, which is a topic highlighted by recent studies (Miller 2018). In terms of political views, respondents who self-classify as extremely liberals or liberals tend to be more pro-immigration (increased a little and increased a lot), compared to other groups. For instance, 43.01 percent of extremely liberals and 32.77 percent of liberals are either in favor of immigration increasing a little or increasing a lot. On the other hand, less than 14 percent of respondents within each of the moderate and conservative categories are pro-immigration. Those with high racial resentment tend to be more anti-immigration than those in the low and medium categories. Finally, individuals who are not 
very proud or not proud at all of the U.S. economic achievement tend to be more antiimmigration than those in other categories.

\section{>> Table $3 \ll<<$}

Table 4 provides overall percentages of county-level variables (proportion of unemployment, college graduates, Protestants/Catholics, and immigrants) by immigration opinion. Due to data availability, these estimates were performed only for 2008, 2010, 2012, and 2014. As explained above, the first three variables were estimated based on GSS. Proportion of immigrants was based on data from ACS five-year estimates. These proportions were estimated after we merged them to our individual-level data and include only observations with valid values for our variables of interest (year, sex, race/ethnicity, age group, education degree, religion, occupation, region of interview, area of residence at age 16 , and political party affiliation). Overall, these proportions of each county-level variable do not have significant fluctuations between 2008 and 2014. We observe a counterintuitive trend of individuals with pro-immigration opinion (increased a lot category) living in counties with higher unemployment rates, looking at each year separately. Individuals with pro-immigration opinion seem to be living in counties with higher proportions of college graduates, as expected (Moore and Ovadia 2006). Those with less pro-immigration opinion (reduced a lot category) seem to be living in areas with higher concentrations of Protestants and Catholics, which is consistent with previous findings (Ellison and Musick 1993, Moore and Ovadia 2006). However, proportion of unemployment, college graduates, and Protestants/Catholics at the county level do not seem to be strongly correlated with individual opinion about immigration. Finally, immigration opinion seems to have a stronger correlation with the proportion of immigrants at the county level. Individuals tend to be more pro-immigration in areas with higher levels of immigrants, and vice- 
versa (Hood III and Morris 1997, McLaren 2003, Dixon 2006, Haubert and Fussell 2006). In the next section, we estimate multivariate regression models to verify whether the bivariate associations observed above are statistically significant after controlling for the effects of all independent variables on our outcome variable.

>> Table $4<<<$

\section{Multivariate results}

The following stage in our analysis is to understand how a series of independent variables are associated with opinion about how should the number of immigrants to America be nowadays (dependent variable), controlling for all variables. We estimated several models which are available in Appendix A. On sub-sections 5.1 (main generalized ordered logit model), 5.3

(racial resentment), 5.4 (economic achievement and robustness check), 5.5 (county-level estimates), we concentrate the analysis on models that included only political party affiliation (instead of political views), because we have a bigger sample size throughout the different models. We do also interpret associations of political views with immigration opinion on section 5.2 .

\subsection{Main generalized ordered logit model}

Table 5 illustrates odds ratios estimated with a generalized ordered logit model predicting the dependent variable. This model includes a series of independent variables: year, sex, race/ethnicity, age group, education degree, religion, occupation, region of interview, area of residence at age 16 , and political party affiliation. When the proportional odds/parallel lines assumption is not violated, the odds ratios of going up in the pro-immigration scale (dependent 
variable) are constant across the several categories of this variable. Thus, empty cells in Table 5 denote that estimated coefficients for each set of independent variables are similar across categories of the dependent variable (do not violate parallel lines assumption).

\section{>> Table $5 \ll<$}

Results indicate that respondents are more likely to be pro-immigration in recent years, compared to 2004, controlling for the other independent variables (Table 5). For instance, people in 2012 were 1.21 times more likely to be in upper levels of the dependent variable versus being at the current level or below, compared to people in 2004. This odds ratio increased to 1.24 in 2014 and 1.53 in 2016. Opinion about immigration was not statistically different in 2008 and 2010 compared to 2004. Difference between women and men was not statistically significant in relation to their opinions toward immigration.

Regarding race/ethnicity, Blacks, Hispanics, and people of other races/ethnicities are more likely to be pro-immigration than Whites, controlling for the other covariates (Table 5). All estimates are statistically significant. Coefficients for race/ethnicity indicate that this variable violated the proportional odds/parallel lines assumption, so the model estimated specific odds ratios for each category of the dependent variable. Blacks are 1.50 times more likely to be above the reduced a lot category versus being at this category, compared to Whites. The odds ratios for Blacks increase across the pro-immigration scale. They are 2.40 times more likely to be above the increased a little category versus being at this category or below, compared to Whites. Hispanics have even higher chances of being pro-immigration, compared to Whites. More specifically, Hispanics are 2.13 times more likely to be above the reduced a lot category versus being at this category, compared to Whites. The odds ratio decreases to 1.74 for Hispanics being above remain the same category versus being at this category or below, compared to Whites. 
Finally, Hispanics are 3.11 times more likely to be above the increased a little category versus being at this category or below, compared to Whites.

In relation to age, younger people tend to be more pro-immigration than older people (Table 5). For instance, people between 18 and 24 year of age are 1.63 times more likely to be above the reduced a lot category versus being at this category, compared to people between 25 and 44 years of age. The estimated odds ratios for the 18-24 age group decrease throughout the pro-immigration scale. For people in the 45-64 age group, they are 22 percent $\left[(0.78-1)^{*} 100\right]$ less likely to increase in the pro-immigration scale, compared to the reference category. Those in the 65-89 age group are 12 percent less likely to increase in the pro-immigration scale, compared to the 25-44 age group. The likelihood in these two oldest age groups are the same across all levels of the dependent variable.

Table 5 also indicates that support for an increase on immigration rises among better educated people. For most categories of education (except junior college), the proportion odds/parallel lines assumption was violated. As a result, the model estimated specific odds ratios for each category of the dependent variable. People with less than a high school degree are 27 percent less likely to be above the reduced a lot category versus being at this category, compared to people with a high school diploma. However, this comparison inverts and the least educated group shows higher chances of being above the last categories of the dependent variable, compared to the reference category. For instance, people with less than a high school education are 1.73 times more likely to be above the increased a little category versus being at this category or below, compared to those with high school. People with bachelor's or graduate degree are even more likely to be pro-immigration, compared to the reference category. Both these highest educational categories are around twice as likely to be above the reduced a lot category than 
being at this category, compared to those with high school. These odds decrease in magnitude throughout the pro-immigration scale. In the category of above increased a little, coefficient for those with a bachelor's is not statistically significant.

Estimates regarding religion indicate that respondents in the Catholic, Jewish, other religion, and none categories tend to be more pro-immigration than Protestants (Table 5). For instance, Catholics are 1.15 times more likely to increase in the pro-immigration scale than the reference category. Christians are not statistically different than Protestants. For most categories of this variable, the proportion odds/parallel lines assumption was not violated (except for category of no religion).

In terms of occupation, results indicate that usually people in blue-collar occupations are less likely to be in upper levels of the pro-immigration scale versus being at the current level or below, compared to people in management, business, science, and arts (Table 5). The occupation variable did not violate the proportional odds/parallel lines assumption, so the model estimated one set of odds ratios that applies to all categories of the dependent variable. For instance, looking at the statistically significant coefficients, these estimates are 21 percent less likely in sales, office, 29 percent less likely in natural resources, construction, maintenance, 14 percent less likely in production, transportation, material moving, and 35 percent less likely in military occupations.

Estimates for region of interview suggest that residents in all regions are more likely to be pro-immigration than those living in South Atlantic (Table 5). Statistically significant results for being in upper levels of the pro-immigration scale versus being at the current level or below are found for residents in New England (1.36 more likely), East North Central (1.23 more likely), West North Central (1.26 more likely), Mountain (1.45 more likely), and Pacific (1.44 
more likely). In the Pacific region, odds ratios loose magnitude throughout the pro-immigration scale and are not statistically significant for above remain the same and above increased a little.

In relation to area of residence at age 16 , results indicate that people who lived in foreign countries, big-city suburbs, or cities with more than 250,000 inhabitants are more likely to be pro-immigration than people who lived in small towns (Table 5). These estimates suggest that people who are exposed to areas with higher concentration of foreign-born individuals (foreign countries and American big cities) are usually more likely to be pro-immigration than people who lived in areas with higher percentages of native-born individuals (country/non-farms, farms, small towns, and mid-sized cities). For instance, people who lived in foreign countries are 3.39 times more likely to be above the reduced a lot category versus being at this category, compared to people who lived in towns with less than 50,000 inhabitants. The odds ratios decrease in magnitude for this foreign-country category throughout the pro-immigration scale. In any case, people who lived in foreign countries still show high chances to be above the increased a little category (1.71 times more likely) versus being at this category or below, compared to the reference category. People who lived in big-city suburbs are 1.15 times more likely to be in upper categories of the pro-immigration scale versus being at the current level or below, compared to people who lived in towns. For people who lived in cities with more than 250,000 inhabitants the chances of being above certain categories of the pro-immigration scale starts as not statistically significant and increases throughout this scale. For instance, people in these big cities are 1.39 times more likely to be above the increased a little category versus being at this category or below, compared to the reference group. People who lived in the country/non-farm or in cities between 50,000 and 250,000 inhabitants are not statistically different than people who lived in towns. People who lived in farms are 16 percent less likely to be in upper levels of the 
pro-immigration scale than being at the current level or below, compared to the reference category.

According to Table 5, those who are self-described as strong Democrats and Independents near Democrats are more pro-immigration than Democrats. On the other hand, Independents near Republicans, Republicans, and strong Republicans are less pro-immigration than the reference category. More specifically, strong Democrats are 1.21 times more likely to be above the reduced a lot category versus being at this category, compared to Democrats. These odds equal 1.23 among Independents near Democrats. These odds ratios are the same throughout the pro-immigration scale for Independents near Democrats, but they increase among Strong Democrats. For instance, strong Democrats are 1.59 times more likely to be above the increased a little category versus being at this category or below, compared to the reference group. Independent near Republicans and Republicans are around 30 percent less likely to be in upper levels of the pro-immigration scale versus being at the current level or below, compared to Democrats. These estimates are even stronger in magnitude among strong Republicans, reaching 40 percent less likely, compared to the reference category. Finally, people in other parties are statistically different than Democrats in the remain the same category (2.10 times more likely). These strong differentials on attitudes toward immigration by political party affiliation are not so dubious as previous studies suggested (Neiman, Johnson, and Bowler 2006).

\subsection{Political views}

In Table A1 of Appendix A, we illustrate the same model described above as model 1. Furthermore, model 2 includes information on political views, instead of political party affiliation. Model 3 adds both political party and political views in addition to all other 
independent variables. Sample size decreased from model 1 to models 2 and 3, because fewer respondents answered the question about political views. We maintained the full sample in model 1, as a way to do not discard a significant number of respondents from our analysis. Results did not change significantly among these three models (besides political party and political views themselves). Most categories of independent variables that do not violate the proportional odds/parallel lines assumption remained the same in the three models. Exceptions were observed for race/ethnicity, age group, and religion.

Model 2 in Table A1 includes information about political views, instead of political party affiliation. Results indicate that respondents who self-classify as extremely liberals, liberals, or slightly liberals are more pro-immigration, compared to moderates. Odds ratios for extremely liberals increase throughout the pro-immigration scale, reaching 4.30 times higher chances of being above the increased a little category than at this category or below, in relation to moderates. Those who self-classify as slightly conservatives, conservatives, and extremely conservatives tend to be less pro-immigration than moderates (odds ratios below one unit and significant). Slightly conservatives present statistically significant odds ratios only in the category of above increased a little (37 percent less likely). Extremely conservatives are 50 percent less likely to be above reduced a lot versus being at this category, compared to moderates.

In order to measure which ideological variable has stronger associations with opinion about immigration, model 3 in Table A1 includes both political party affiliation and political views. Overall, results suggest that political parties better capture anti-immigration opinions among right-wing groups (Independents near Republicans, Republicans, and strong Republicans), while political views better capture pro-immigration opinions among left-wing 
groups (extremely liberals, liberals, and slightly liberals). However, these estimates give confusing results because political party affiliation and political views tend to measure the same political ideological dimension.

\subsection{Racial resentment}

As a way to verify whether racial resentment has significant correlations with opinion about immigration (Miller 2018), we estimated a series of models, which are available in Table A2 of Appendix A. In Table 6, we illustrate only coefficients related to racial resentment from one of these models. Sample sizes are smaller in Table 6, compared to Table 5, because fewer respondents answered questions related to racial resentment. Overall, results suggest that people with high levels of racial resentment tend to be less pro-immigration than people with medium levels of racial resentment (odds ratios below one unit). For instance, people with high levels of racial resentment are 56 percent less likely to be above the reduced a lot category versus being at this category, compared to the reference category. These odds are less negative as we move up in the pro-immigration scale, but results remain statistically significant. On the other hand, people with low levels of racial resentment are more likely to be pro-immigration than the reference category (odds ratios above one unit). These differentials increase in magnitude throughout the

pro-immigration scale and are significant in the upper three categories. For instance, those in the low level of racial resentment are 1.71 times more likely to be above the increased a little category versus being at this category or below, compared to the reference category.

\section{>> Table $6<<<$}




\subsection{Economic achievement and robustness check}

In another set of estimates, we aimed to verify whether opinion about U.S. economic achievement was correlated with opinion about immigration. This question was asked to a smaller sample of respondents in GSS, covering only the years of 2004 and 2014. In 2004, people who answered the question related to opinion about U.S. economic achievement did not provide information about political views and vice-versa. Thus, models that include both opinions about economic achievement and political views relate only to 2014. Generalized ordered logit models did not converge when we included opinion about economic achievement, probably due to the reduced sample size.

As a strategy to capture associations between opinions about U.S. economic achievement and immigration, we estimated ordinary least squares (OLS) models. Since our dependent variable is measured at the ordinal-level of measurement, OLS models are not appropriate in statistical terms. As a way to verify whether these linear models would capture similar associations between the categories of our independent variables and the dependent variable, we estimated models similar to those in Tables A1 and A2 (without opinion about U.S. economic achievement), which are detailed in Table A3 of Appendix A. Model 1 (with political party), model 2 (with political views), and model 3 (with political party and political views) in Table A3 have the same independent variables as models in Table A1. Models 4, 5, and 6 (with the inclusion of racial resentment) in Table A3 have the same independent variables as models in Table A2. Thus, these models serve as robustness checks for the previous estimates provided by generalized ordered logit models. Overall, results in models 1, 2, and 3 in Table A3 follow the

same directions as those presented in Table A1. The same is observed between models 4, 5, and 6 in Table A3 and those illustrated in Table A2. These estimates are an indication that OLS 
models might not be appropriate to deal with an ordinal-level dependent variable, but they do capture similar trends and associations of all independent variables with opinion about immigration.

We now concentrate the analysis on coefficients related to racial resentment and opinion about U.S. economic achievement, summarized in Table 7. Model 4 indicates that those with low levels of racial resentment are more pro-immigration (positive coefficients) and those with high levels of racial resentment are less pro-immigration (negative coefficients), compared to the reference category. These results are statistically significant. Model 7 includes opinion about U.S. economic achievement, instead of racial resentment. Results suggest that people who are not very proud of U.S. economic achievement are less pro-immigration (negative coefficients) than those who are somewhat proud with the economy. Moreover, those who are very proud of U.S. economic achievement are more pro-immigration (positive coefficients), compared to the reference category. These results are not statistically significant.

\section{>> Table $7 \ll<$}

Finally, model 10 in Table 7 includes both racial resentment and opinion about U.S. economic achievement. Results indicate that associations between opinion toward immigration are stronger with racial resentment than with opinion about economic achievement. For instance, coefficient related to high level of racial resentment is negative and significant, meaning that these people tend to be less pro-immigration than the reference category. People with low level of racial resentment have a positive and significant coefficient, which means that these respondents tend to be more pro-immigration than those with medium levels of racial resentment. Regarding opinion about U.S. economic achievement, directions of coefficients are similar to model 7, but they are still not statistically significant. Stronger associations of racial 
resentment with attitudes toward immigration, compared to associations between opinions about U.S. economic achievement and immigration, is in line with previous studies that estimated models using ANES data (Miller 2018).

\subsection{County-level estimates}

We include county-level variables that might influence individual opinions about immigration. These variables measure proportion of unemployment, college graduates, Protestants/Catholics, and immigrants in each county and year. Complete generalized ordered logit models using contextual variables are available in Table A4 of Appendix A. We summarize results about county-level variables in Table 8 . County-level variables did not violate the proportional odds/parallel lines assumption, so the model estimated one set of odds ratios that applies to all categories of the dependent variable. People who live in counties with higher proportions of college graduates and higher proportions of immigrants are more likely to be in upper levels of the pro-immigration scale versus being at the current level or below (odds ratios above one unit). These results are statistically significant. For instance, controlling for all other independent variables, if a county experiences an increase of one percent on college graduates, individuals will be 1.4 times more likely to move to upper levels of the pro-immigration scale. This result is even stronger when there is an increase of one percent on immigrants in the county, increasing by 2.2 times the chances of someone moving to upper levels of the pro-immigration

scale. On the other hand, people living in counties with higher proportions of unemployment and higher proportions of Protestants/Catholics are less likely to be in upper levels of the proimmigration scale, versus being at the current level or below (odds ratios below one unit), but these results are not statistically significant. 


\section{>> Table $8<<<$}

\section{Discussion and conclusion}

We estimated associations of attitudes toward immigration with several demographic, socioeconomic, political, and contextual factors. This study provides an innovative approach to contribute to the literature about attitudes toward immigration, which includes: (1) analysis of GSS and ACS data from 2004 to 2016; (2) inclusion of individual-level and county-level variables in multivariate models. We were able to include area-level variables related to proportion of unemployment, college graduates, Protestants/Catholics, and immigrants, due to access to GSS Sensitive Data Files; (3) better understanding of the association of several independent variables with immigration attitude by estimating generalized ordered logit models, instead of logistic regressions, ordinal regressions, or multinomial logistic regressions; and (4) inclusion of disaggregated categories on race/ethnicity, age group, education degree, religion, occupation, region of interview, area of residence at age 16, political party affiliation, political views, racial resentment, and opinion about U.S. economic achievement.

Our overall results suggest that support to immigration has been increasing over time. However, the majority of respondents still support a reduction in immigration. Three main patterns emerged from our analysis. More specifically, opinion about immigration is associated with: race and class; political ideology; and exposure to immigrants.

First, there is a clear race and social class divide among those who support increasing immigration and those who wish for a reduction in the number of immigrants. Non-Whites (Blacks, Hispanics, and others) are more likely to be in favor of an increase on the number of immigrants than Whites. People with a bachelor's degree, or with a graduate degree are more 
likely to support immigration, compared to those with a high school degree. Models with contextual variables indicate that people who live in counties with higher proportions of college graduates are more likely to be pro-immigration, which is in line with previous studies (Moore and Ovadia 2006). People in blue collar occupations such as those working on natural resources, construction, maintenance, production, transportation, material moving, and military occupations are less likely to support immigration, in comparison to people in management, business, science, and arts occupations. People with low levels of racial resentment have higher chances to be in favor of an increase in immigration, compared to those with medium levels of racial resentment. On the other hand, those with high levels of racial resentment are less proimmigration than the reference category. Finally, opinion about immigration has stronger associations with racial resentment than with opinion about U.S. economic achievement, which is in line with recent studies using ANES data (Miller 2018).

Similar to the race and class divide, there is also a clear divide in political ideology in immigration attitudes. People self-identified as strong Democrats, Independents near Democrats, and those in other parties are more likely to be in favor of an increase on the number of immigrants, compared to Democrats. Independents near Republicans, Republicans, and strong Republicans have the lowest chances to support immigration. We also verified that strong Democrats and Democrats are increasingly pro-immigration over time. Republicans and strong Republicans are stable anti-immigration over time. These strong differentials on attitudes toward immigration by political party affiliation are not so dubious as previous studies suggested (Neiman, Johnson, and Bowler 2006). Furthermore, people with political views that are extremely liberal, liberal, and slightly liberal are more likely to be in favor of immigration, compared to moderates. People who self-identify as slightly conservative, conservative, and 
extremely conservative have the lowest chances of being pro-immigration. These results are aligned with previous studies, which suggested that political views present the typical proimmigration opinions among left-wing individuals and anti-immigration among right-wing individuals (Chandler and Tsai 2001, Haubert and Fussell 2006)

Third, exposure to immigrants is likely to shape the public opinion about immigration. Individuals living in counties with higher proportions of immigrants tend to be more proimmigration, following previous analyzes (Hood III and Morris 1997, McLaren 2003, Dixon 2006, Haubert and Fussell 2006). Similarly, people who lived in areas at the age of 16 that tend to have higher proportions of foreign-born individuals (foreign countries and U.S. big cities) are more likely to support immigration.

In other findings, there is no difference by sex on attitudes toward immigration. The youngest age group (18-24) has the highest likelihood to want an increase on immigration. The disaggregated age group variable provided a deeper understanding on attitudes toward immigrants than a binary variable related to the millennial generation, as suggested by previous studies (Ross and Rouse 2015). Protestants are less likely to support immigration, in relation to all other religion groups. More specifically, people who reported being Catholic, Jewish, having other religion, or no religion present higher chances of wanting to increase the number of immigrants, compared to Protestants. People who self-identify as Christians do not have different opinions regarding immigration, in relation to Protestants. These results are in line with findings from previous studies (Ellison and Musick 1993, Moore and Ovadia 2006). People living in the South Atlantic region (Delaware, Maryland, West Virginia, Virginia, North Carolina, South Carolina, Georgia, Florida, District of Columbia) are the least likely to support an increase in immigration. 
We emphasize that all these results are associations of several independent variables with opinion about immigration. We are not performing a causal analysis, since there are issues of reverse causality in our estimations. For example, we are not evaluating: (1) whether a county with higher percentages of college graduates and immigrants tend to shape opinion about immigration; or (2) whether foreign-born individuals, people with college degree, and those with more positive views toward immigration are moving to areas with already higher percentages of college graduates, higher percentages of immigrants, and more positive views towards immigrants. In any case, the positive outcome of this analysis is the estimation of multivariate models that consider a series of factors correlated to immigration opinion, using individual-level and contextual-level data representative to the U.S. adult population for several years. Furthermore, we implement this analysis taking advantage of a regression model that captures different levels of associations of our independent variables with the dependent variable, as we move up throughout the categories of the pro-immigration scale.

Our study is novel in several ways. First, we are capturing several years of public opinion about immigration. Our last data wave, 2016, reflects the sociopolitical climate of the latest presidential election. Immigration policies were at the core of the Republican contender's campaign and continue to be an important element of his presidential administration. The Republicans' attitudes towards immigration as we see in our analysis is overwhelmingly antiimmigration, and that has had profound implications for immigration policy in the last three years. We are also able to observe in our findings a clear partisan divide in this issue. This is also a reflection of greater political polarization in the United States in the last decade or so. The right is moving farther to the right, as seen with the rise of the Tea Party, and the left is moving farther to the left, as observed with the rise of prominent socialist democrat politicians in the last few 
years. The partisan divide is usually articulated as a race, class, and age divide. In our analysis, we find some evidence to support these claims. On one hand, those who are Democrats or with a liberal political ideology, those who have higher levels of education and occupation, as well as non-Whites and the youngest respondents were supportive of immigration. On the other hand, those who are Republicans or conservative leaning individuals, those with lower socioeconomic status, and those in older age groups tend to be against increases in immigration. Finally, exposure to immigrants seems to be a predictor of positive attitudes towards immigration. Based on our results, this could mean that positive attitudes towards immigration will continue to increase as immigrants move to new destinations. However, it remains to be seen whether increased exposure in new immigrant destinations has the same effect in conservative dominated environments. 
Table 1. Sample size of adult population by year and opinion about how should the number of immigrants to America be nowadays, United States, 2004-2016

\begin{tabular}{|c|c|c|c|c|c|c|}
\hline Year & $\begin{array}{c}\text { Reduced } \\
\text { a lot } \\
\end{array}$ & $\begin{array}{c}\text { Reduced } \\
\text { a little }\end{array}$ & $\begin{array}{c}\text { Remain } \\
\text { the same }\end{array}$ & $\begin{array}{c}\text { Increased } \\
\text { a little } \\
\end{array}$ & $\begin{array}{c}\text { Increased } \\
\text { a lot } \\
\end{array}$ & Total \\
\hline 2004 & 527 & 552 & 678 & 129 & 75 & 1,961 \\
\hline 2008 & 381 & 305 & 440 & 104 & 45 & 1,275 \\
\hline 2010 & 350 & 342 & 483 & 135 & 60 & 1,370 \\
\hline 2012 & 290 & 284 & 502 & 114 & 57 & 1,247 \\
\hline 2014 & 347 & 371 & 643 & 166 & 75 & 1,602 \\
\hline 2016 & 351 & 410 & 727 & 216 & 106 & 1,810 \\
\hline Total & 2,246 & 2,264 & 3,473 & 864 & 418 & 9,265 \\
\hline
\end{tabular}

Source: 2004, 2008, 2010, 2012, 2014, and 2016 General Social Surveys (GSS). 
Figure 1. Distribution of adult population by opinion about how should the number of immigrants to America be nowadays, United States, 2004-2016

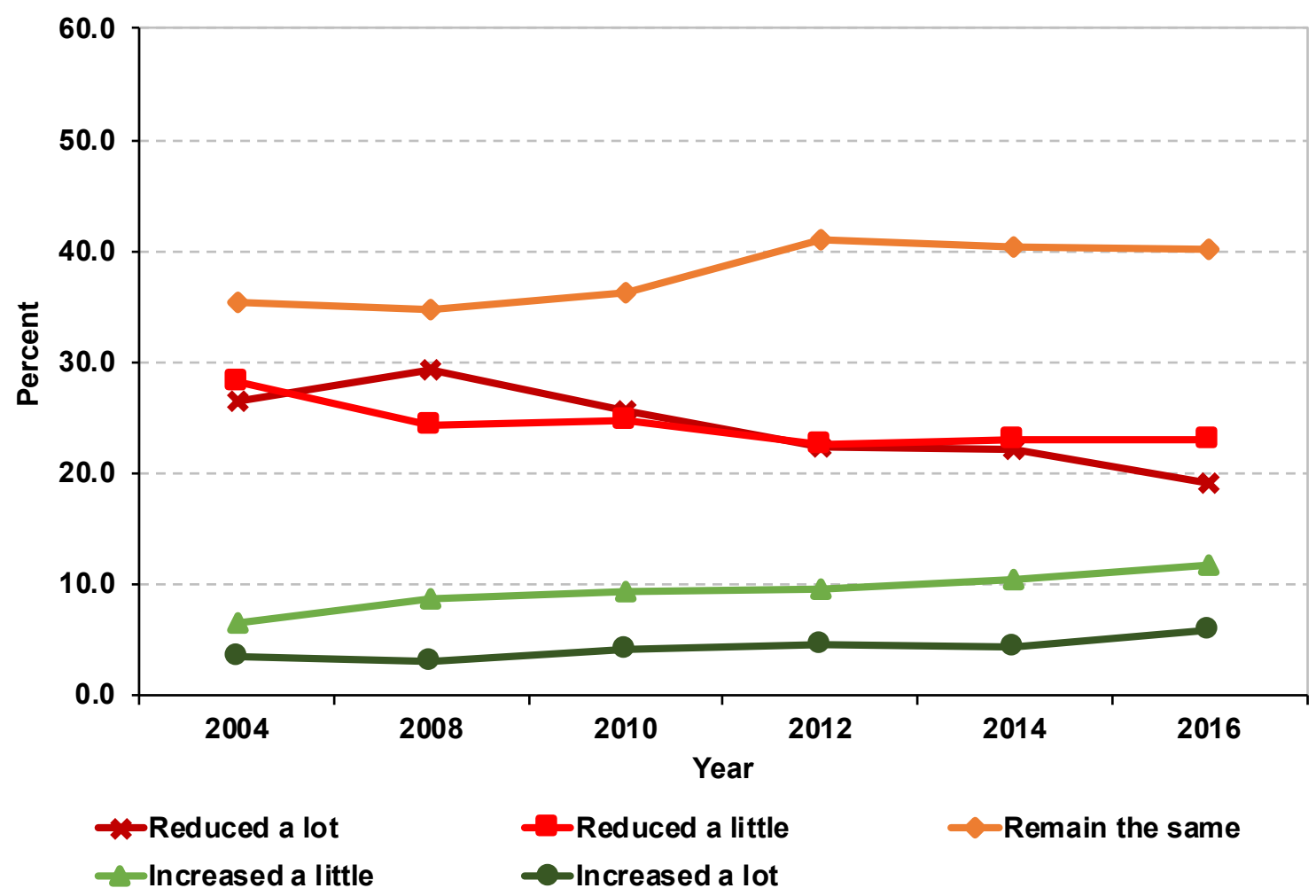

Note: The percentages provided in this figure considered the complex survey design of the General Social Survey. Source: 2004, 2008, 2010, 2012, 2014, and 2016 General Social Surveys. 
Table 2. Distribution of adult population by several independent variables and opinion about how should the number of immigrants to America be nowadays, United States, 2016

\begin{tabular}{|c|c|c|c|c|c|c|}
\hline Independent variables & $\begin{array}{c}\text { Reduced } \\
\text { a lot } \\
\end{array}$ & $\begin{array}{c}\text { Reduced } \\
\text { a little }\end{array}$ & $\begin{array}{l}\text { Remain } \\
\text { the same }\end{array}$ & $\begin{array}{c}\text { Increased } \\
\text { a little }\end{array}$ & $\begin{array}{c}\text { Increased } \\
\text { a lot }\end{array}$ & $\begin{array}{l}\text { Sample } \\
\text { size }\end{array}$ \\
\hline $\begin{array}{l}\text { Sex } \\
\text { Female } \\
\text { Male }\end{array}$ & $\begin{array}{l}19.02 \\
19.47 \\
\end{array}$ & $\begin{array}{l}22.15 \\
23.82 \\
\end{array}$ & $\begin{array}{l}40.87 \\
39.19 \\
\end{array}$ & $\begin{array}{l}12.28 \\
11.37 \\
\end{array}$ & $\begin{array}{l}5.69 \\
6.15\end{array}$ & $\begin{array}{r}1,009 \\
801 \\
\end{array}$ \\
\hline $\begin{array}{l}\text { Race/ethnicity } \\
\text { Non-Hispanic white } \\
\text { Non-Hispanic black } \\
\text { Hispanic } \\
\text { Other }\end{array}$ & $\begin{array}{r}22.66 \\
15.72 \\
10.00 \\
9.99\end{array}$ & $\begin{array}{l}26.59 \\
16.68 \\
16.23 \\
13.55\end{array}$ & $\begin{array}{l}36.07 \\
45.84 \\
48.41 \\
51.14\end{array}$ & $\begin{array}{l}11.36 \\
12.24 \\
12.12 \\
15.37\end{array}$ & $\begin{array}{r}3.32 \\
9.52 \\
13.24 \\
9.94\end{array}$ & $\begin{array}{r}1,215 \\
286 \\
227 \\
82\end{array}$ \\
\hline $\begin{array}{l}\text { Age group } \\
18-24 \\
25-44 \\
45-64 \\
65-89 \\
\end{array}$ & $\begin{array}{l}12.30 \\
16.25 \\
22.73 \\
22.60 \\
\end{array}$ & $\begin{array}{l}20.10 \\
19.20 \\
27.31 \\
23.98 \\
\end{array}$ & $\begin{array}{l}45.94 \\
44.89 \\
36.12 \\
34.45 \\
\end{array}$ & $\begin{array}{l}15.20 \\
11.82 \\
10.20 \\
12.58 \\
\end{array}$ & $\begin{array}{l}6.46 \\
7.85 \\
3.64 \\
6.40\end{array}$ & $\begin{array}{l}161 \\
612 \\
638 \\
399 \\
\end{array}$ \\
\hline $\begin{array}{l}\text { Education degree } \\
\text { Less than high school } \\
\text { High school } \\
\text { Junior college } \\
\text { Bachelor } \\
\text { Graduate }\end{array}$ & $\begin{array}{l}22.53 \\
22.80 \\
17.90 \\
11.56 \\
12.49 \\
\end{array}$ & $\begin{array}{l}20.30 \\
23.58 \\
25.29 \\
25.58 \\
17.08 \\
\end{array}$ & $\begin{array}{l}37.00 \\
39.53 \\
38.25 \\
40.71 \\
45.64 \\
\end{array}$ & $\begin{array}{r}9.68 \\
9.85 \\
12.93 \\
16.16 \\
15.27 \\
\end{array}$ & $\begin{array}{r}10.49 \\
4.24 \\
5.63 \\
5.98 \\
9.51 \\
\end{array}$ & $\begin{array}{l}214 \\
923 \\
146 \\
336 \\
191\end{array}$ \\
\hline $\begin{array}{l}\text { Religion } \\
\text { Protestant } \\
\text { Catholic } \\
\text { Christian } \\
\text { Jewish } \\
\text { Other } \\
\text { None } \\
\end{array}$ & $\begin{array}{r}22.17 \\
18.02 \\
15.07 \\
11.92 \\
9.85 \\
16.83 \\
\end{array}$ & $\begin{array}{r}28.10 \\
21.95 \\
19.96 \\
9.42 \\
9.66 \\
17.01 \\
\end{array}$ & $\begin{array}{l}34.97 \\
41.30 \\
47.75 \\
38.71 \\
58.92 \\
45.84 \\
\end{array}$ & $\begin{array}{r}9.40 \\
13.03 \\
6.46 \\
31.21 \\
7.98 \\
14.74 \\
\end{array}$ & $\begin{array}{r}5.37 \\
5.70 \\
10.77 \\
8.75 \\
13.58 \\
5.58 \\
\end{array}$ & $\begin{array}{r}884 \\
409 \\
22 \\
31 \\
71 \\
393 \\
\end{array}$ \\
\hline $\begin{array}{l}\text { Occupation } \\
\text { Manag., busin., science, arts } \\
\text { Service } \\
\text { Sales, office } \\
\text { Natural res., constr., maint. } \\
\text { Prod., transp., mat. moving } \\
\text { Military } \\
\text { Unspecified } \\
\text { Unemployed }\end{array}$ & $\begin{array}{r}16.00 \\
18.88 \\
19.13 \\
29.93 \\
21.98 \\
31.01 \\
0.00 \\
19.09 \\
\end{array}$ & $\begin{array}{l}22.07 \\
24.91 \\
25.75 \\
24.05 \\
17.03 \\
13.95 \\
36.32 \\
23.51 \\
\end{array}$ & $\begin{array}{l}41.79 \\
38.48 \\
40.64 \\
31.11 \\
44.28 \\
17.06 \\
47.26 \\
37.04 \\
\end{array}$ & $\begin{array}{l}14.15 \\
10.32 \\
10.17 \\
10.73 \\
11.14 \\
17.06 \\
16.42 \\
10.05\end{array}$ & $\begin{array}{r}5.99 \\
7.41 \\
4.31 \\
4.18 \\
5.56 \\
20.92 \\
0.00 \\
10.32 \\
\end{array}$ & $\begin{array}{r}635 \\
356 \\
369 \\
155 \\
215 \\
10 \\
9 \\
61 \\
\end{array}$ \\
\hline $\begin{array}{l}\text { Region of interview } \\
\text { New England } \\
\text { Middle Atlantic } \\
\text { East North Central } \\
\text { West North Central } \\
\text { South Atlantic } \\
\text { East South Central } \\
\text { West South Central } \\
\text { Mountain } \\
\text { Pacific }\end{array}$ & $\begin{array}{l}19.78 \\
17.11 \\
20.97 \\
18.24 \\
22.63 \\
20.57 \\
22.47 \\
18.30 \\
11.92 \\
\end{array}$ & $\begin{array}{l}14.76 \\
23.39 \\
27.29 \\
26.43 \\
22.88 \\
25.53 \\
25.29 \\
15.21 \\
21.57\end{array}$ & $\begin{array}{l}43.79 \\
40.10 \\
35.31 \\
39.67 \\
39.69 \\
31.77 \\
39.75 \\
45.39 \\
45.33\end{array}$ & $\begin{array}{r}18.72 \\
13.14 \\
12.25 \\
9.30 \\
9.41 \\
13.27 \\
4.33 \\
14.29 \\
15.17 \\
\end{array}$ & $\begin{array}{l}2.95 \\
6.26 \\
4.19 \\
6.36 \\
5.39 \\
8.87 \\
8.17 \\
6.81 \\
6.02 \\
\end{array}$ & $\begin{array}{l}108 \\
192 \\
316 \\
127 \\
343 \\
129 \\
191 \\
153 \\
251\end{array}$ \\
\hline $\begin{array}{l}\text { Area of residence at age } \mathbf{1 6} \\
\text { Foreign } \\
\text { Country, non-farm } \\
\text { Farm } \\
\text { Town: }<50,000 \\
\text { City: } 50,000 \text { to } 250,000 \\
\text { Big-city suburb } \\
\text { City: }>250,000\end{array}$ & $\begin{array}{r}4.38 \\
23.77 \\
28.80 \\
21.45 \\
14.89 \\
18.68 \\
21.70\end{array}$ & $\begin{array}{l}10.65 \\
24.01 \\
30.77 \\
25.83 \\
25.48 \\
23.15 \\
16.97 \\
\end{array}$ & $\begin{array}{l}56.34 \\
39.05 \\
24.99 \\
39.64 \\
42.21 \\
38.46 \\
37.40\end{array}$ & $\begin{array}{r}17.29 \\
7.08 \\
10.31 \\
9.88 \\
11.06 \\
16.67 \\
12.45\end{array}$ & $\begin{array}{r}11.34 \\
6.10 \\
5.14 \\
3.20 \\
6.35 \\
3.04 \\
11.48 \\
\end{array}$ & $\begin{array}{l}153 \\
167 \\
144 \\
570 \\
286 \\
241 \\
249 \\
\end{array}$ \\
\hline Total & 19.26 & 23.05 & 39.96 & 11.79 & 5.94 & 1,810 \\
\hline
\end{tabular}

Note: The percentages provided in this table considered the complex survey design of the General Social Survey. The percentages in each row for each year add up to 100 percent. Instead of repeating this information throughout the table, we present the sample size of each category for all independent variables in each year.

Source: 2016 General Social Survey. 
Figure 2. Distribution of adult population by opinion about how should the number of immigrants to America be nowadays by political party affiliation, United States, 2004-2016

Strong Democrats

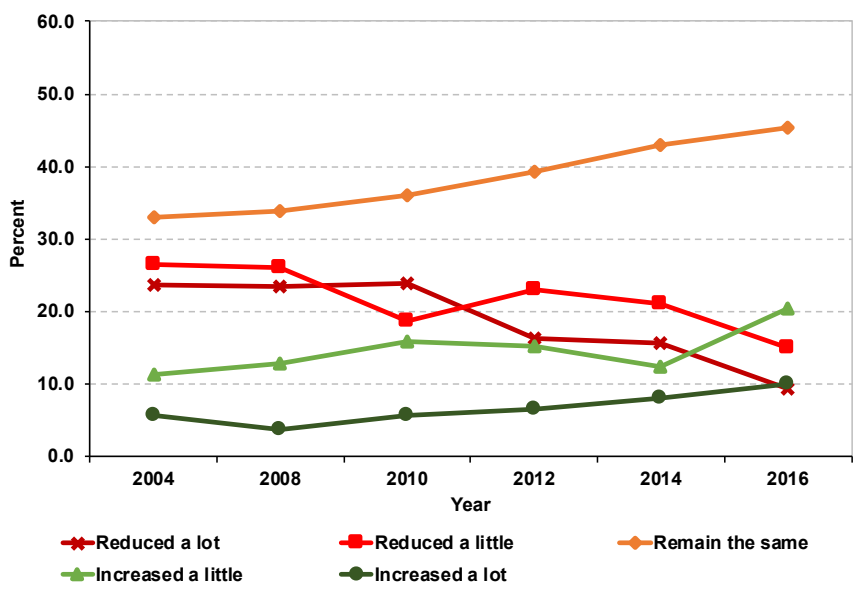

Democrats

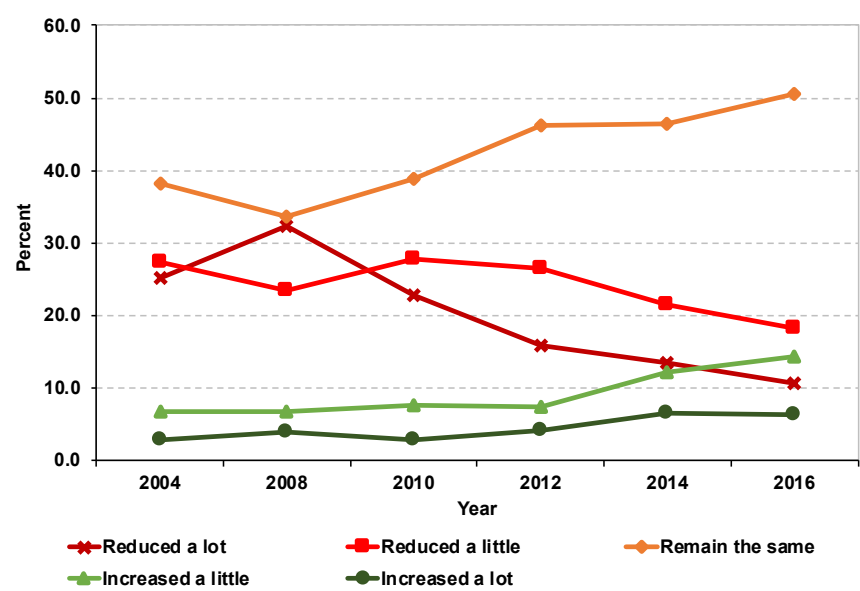

Independents

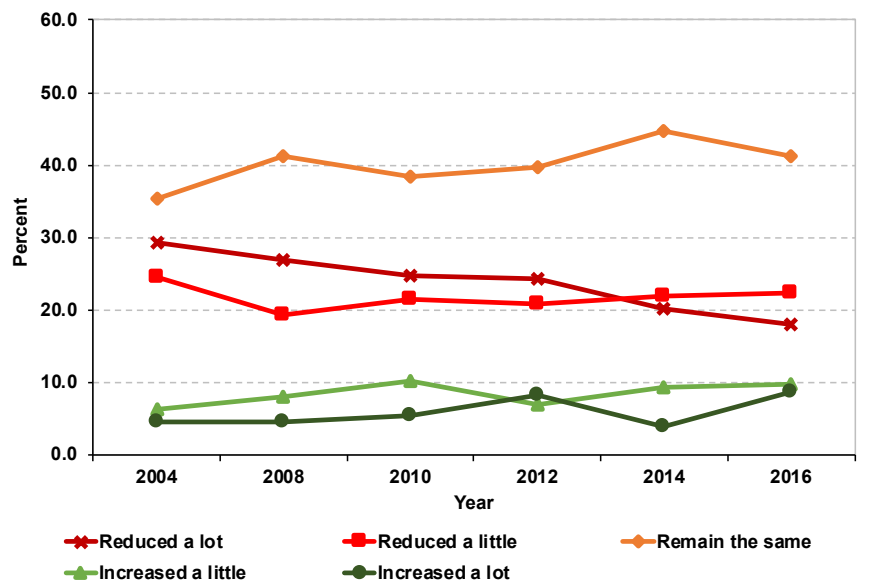

\section{Republicans}

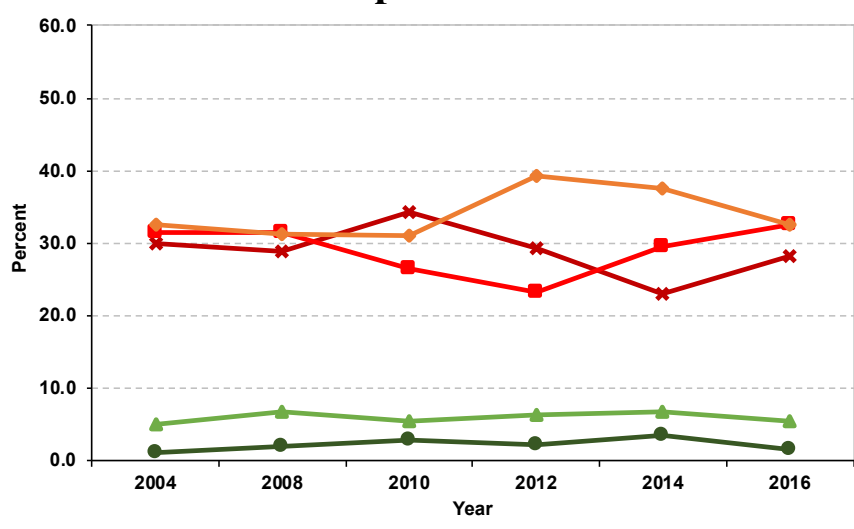

*-Reduced a lot $\quad-$ Reduced a little -Increased a little

$\neg-$ Remain the same

Note: The percentages provided in this figure considered the complex survey design of the General Social Survey. Source: 2004, 2008, 2010, 2012, 2014, and 2016 General Social Surveys.

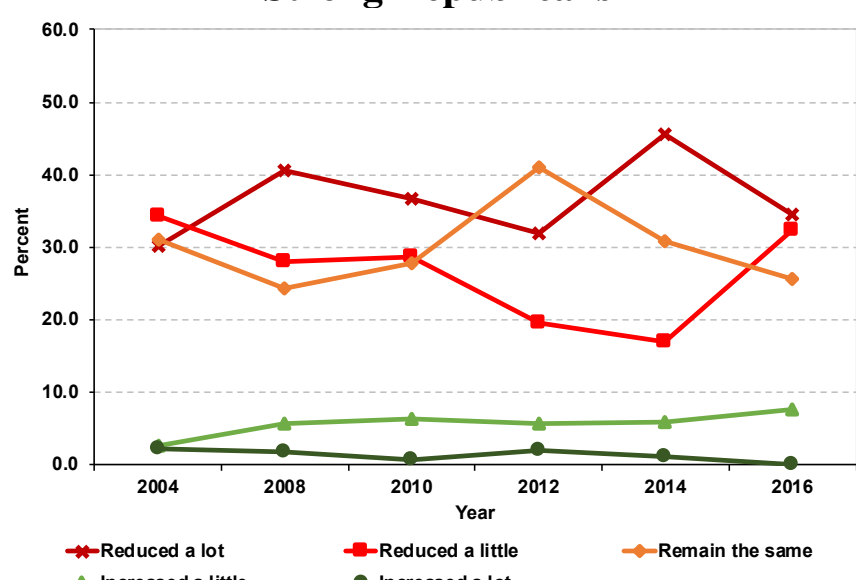


Table 3. Distribution of adult population by political views, racial resentment, and economic achievement and opinion about how should the number of immigrants to America be nowadays, United States, 2014 and 2016

\begin{tabular}{|c|c|c|c|c|c|c|}
\hline Independent variables & $\begin{array}{c}\text { Reduced } \\
\text { a lot } \\
\end{array}$ & $\begin{array}{c}\text { Reduced } \\
\text { a little } \\
\end{array}$ & $\begin{array}{c}\text { Remain } \\
\text { the same }\end{array}$ & $\begin{array}{c}\text { Increased } \\
\text { a little } \\
\end{array}$ & $\begin{array}{c}\text { Increased } \\
\text { a lot }\end{array}$ & $\begin{array}{c}\text { Sample } \\
\text { size }\end{array}$ \\
\hline \multicolumn{7}{|l|}{ Political views (2016) } \\
\hline Extremely liberal & 16.49 & 0.58 & 39.92 & 26.57 & 16.44 & 87 \\
\hline Liberal & 10.57 & 8.92 & 47.74 & 23.27 & 9.50 & 217 \\
\hline Slightly liberal & 9.29 & 19.14 & 45.26 & 17.77 & 8.55 & 196 \\
\hline Moderate & 20.87 & 25.51 & 40.10 & 8.41 & 5.12 & 658 \\
\hline Slightly conservative & 14.38 & 31.75 & 43.56 & 7.01 & 3.30 & 251 \\
\hline Conservative & 30.28 & 32.21 & 27.02 & 7.01 & 3.41 & 270 \\
\hline Extremely conservative & 36.95 & 17.72 & 33.06 & 8.70 & 3.57 & 71 \\
\hline Total & 19.15 & 23.18 & 39.87 & 11.79 & 6.01 & 1,750 \\
\hline \multicolumn{7}{|l|}{ Racial resentment (2016) } \\
\hline Low & 13.11 & 18.43 & 42.59 & 17.31 & 8.56 & 756 \\
\hline Medium & 18.13 & 28.20 & 40.76 & 8.67 & 4.24 & 647 \\
\hline High & 45.38 & 20.01 & 23.05 & 6.33 & 5.23 & 230 \\
\hline Total & 19.64 & 22.59 & 39.13 & 12.29 & 6.35 & 1,633 \\
\hline \multicolumn{7}{|l|}{ U.S. economic achievement (2014) } \\
\hline Very proud & 19.55 & 17.53 & 45.90 & 13.13 & 3.90 & 191 \\
\hline Somewhat proud & 18.50 & 24.32 & 43.21 & 10.57 & 3.38 & 359 \\
\hline Not very proud & 24.19 & 26.55 & 36.77 & 9.46 & 3.03 & 147 \\
\hline Not proud at all & 31.44 & 24.82 & 36.12 & 4.36 & 3.27 & 42 \\
\hline Total & 20.66 & 23.09 & 42.18 & 10.64 & 3.43 & 739 \\
\hline
\end{tabular}

Note: The percentages provided in this table considered the complex survey design of the General Social Survey. The percentages in each row for each year add up to 100 percent. Instead of repeating this information throughout the table, we present the sample size of each category for all independent variables in each year.

Source: 2014 and 2016 General Social Surveys. 
Table 4. Proportion of county-level variables by year and opinion about how should the number of immigrants to America be nowadays, United States, 2008-2014

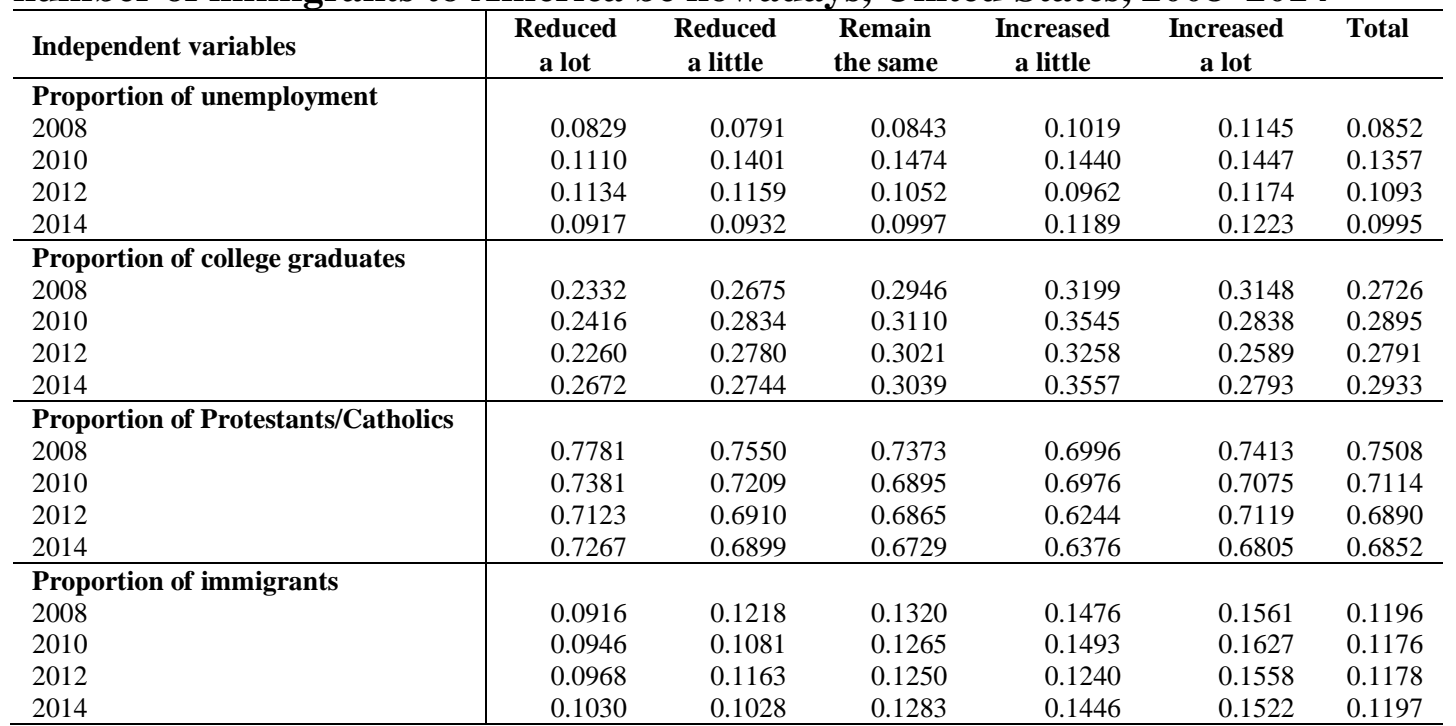

Note: The percentages provided in this table considered the survey design of the American Community Survey.

Source: 2008, 2010, 2012, and 2014 General Social Surveys and American Community Surveys five-year estimates. 
Table 5. Odds ratios from a generalized ordered logit model predicting opinion about how should the number of immigrants to America be nowadays, United States, 2004-2016 (model 1 in Table A1)

\begin{tabular}{|c|c|c|c|c|c|c|c|c|}
\hline \multirow[b]{2}{*}{ Independent variables } & \multicolumn{2}{|c|}{ Above reduced a lot } & \multicolumn{2}{|c|}{ Above reduced a little } & \multicolumn{2}{|c|}{ Above remain the same } & \multicolumn{2}{|c|}{ Above increased a little } \\
\hline & Odds ratio & $\begin{array}{l}\text { Exponential } \\
\text { of std. error }\end{array}$ & Odds ratio & $\begin{array}{l}\text { Exponential } \\
\text { of std. error }\end{array}$ & Odds ratio & $\begin{array}{l}\text { Exponential } \\
\text { of std. error }\end{array}$ & Odds ratio & $\begin{array}{l}\text { Exponential } \\
\text { of std. error }\end{array}$ \\
\hline $\begin{array}{l}\text { Year } \\
2004 \\
2008 \\
2010 \\
2012 \\
2014 \\
2016\end{array}$ & $\begin{array}{r}\text { ref. } \\
0.942 \\
1.074 \\
1.206^{* *} \\
1.244^{* * *} \\
1.526^{* * *}\end{array}$ & $\begin{array}{r}(0.0775) \\
(0.0919) \\
(0.106) \\
(0.102) \\
(0.117)\end{array}$ & & & & & & \\
\hline $\begin{array}{l}\text { Sex } \\
\text { Female } \\
\text { Male }\end{array}$ & $\begin{array}{r}\text { ref. } \\
1.047\end{array}$ & $(0.0488)$ & & & & & & \\
\hline $\begin{array}{l}\text { Race/ethnicity } \\
\text { White } \\
\text { Black } \\
\text { Hispanic } \\
\text { Other } \\
\end{array}$ & $\begin{array}{r}\text { ref. } \\
1.497^{* * *} \\
2.126^{* * *} \\
1.904^{* * *}\end{array}$ & $\begin{array}{l}(0.146) \\
(0.294) \\
(0.372)\end{array}$ & $\begin{array}{r}\text { ref. } \\
1.455^{* * *} \\
2.169^{* * *} \\
1.990^{* * *}\end{array}$ & $\begin{array}{l}(0.119) \\
(0.214) \\
(0.316) \\
\end{array}$ & $\begin{array}{r}\text { ref. } \\
1.534 * * * \\
1.739 * * * \\
1.339 *\end{array}$ & $\begin{array}{l}(0.179) \\
(0.208) \\
(0.228)\end{array}$ & $\begin{array}{r}\text { ref. } \\
2.395^{* * *} * \\
3.113^{* * *} * \\
2.566^{* * *}\end{array}$ & $\begin{array}{l}(0.451) \\
(0.584) \\
(0.579) \\
\end{array}$ \\
\hline $\begin{array}{l}\text { Age group } \\
18-24 \\
25-44 \\
45-64 \\
65-89\end{array}$ & $\begin{array}{r}1.628 * * * \\
\text { ref. } \\
0.780^{* * *} \\
0.875^{*}\end{array}$ & $\begin{array}{c}(0.186) \\
(0.0442) \\
(0.0614)\end{array}$ & $\begin{array}{r}1.216^{* * *} \\
\text { ref. }\end{array}$ & $(0.117)$ & $\begin{array}{r}1.347 * * * \\
\text { ref. }\end{array}$ & $(0.142)$ & $\begin{array}{r}0.965 \\
\text { ref. }\end{array}$ & $(0.187)$ \\
\hline $\begin{array}{l}\text { Education degree } \\
\text { Less than high school } \\
\text { High school } \\
\text { Junior college } \\
\text { Bachelor } \\
\text { Graduate } \\
\end{array}$ & $\begin{array}{r}0.731 * * * \\
\text { ref. } \\
1.074 \\
2.103 * * * \\
2.335 * * * \\
\end{array}$ & $\begin{array}{r}(0.0608) \\
(0.0918) \\
(0.194) \\
(0.307) \\
\end{array}$ & $\begin{array}{r}0.854 * * \\
\text { ref. } \\
1.648 * * * \\
2.128 * * * \\
\end{array}$ & $\begin{array}{l}(0.0678) \\
(0.124) \\
(0.209) \\
\end{array}$ & $\begin{array}{r}1.434 * * * \\
\text { ref. } \\
1.582 * * * \\
2.266 * * * \\
\end{array}$ & $\begin{array}{l}(0.162) \\
\\
(0.153) \\
(0.279) \\
\end{array}$ & $\begin{array}{r}1.732 * * * \\
\text { ref. } \\
1.062 \\
1.392 * \\
\end{array}$ & $\begin{array}{l}(0.286) \\
(0.177) \\
(0.271) \\
\end{array}$ \\
\hline $\begin{array}{l}\text { Religion } \\
\text { Protestant } \\
\text { Catholic } \\
\text { Christian } \\
\text { Jewish } \\
\text { Other } \\
\text { None }\end{array}$ & $\begin{array}{r}\text { ref. } \\
1.149^{* *} \\
1.155 \\
2.003^{* * *} \\
1.622^{* * *} \\
1.144^{*}\end{array}$ & $\begin{array}{r}(0.0689) \\
(0.129) \\
(0.404) \\
(0.221) \\
(0.0900)\end{array}$ & $1.324 * * *$ & $(0.0940)$ & ref. & $(0.122)$ & ref. & $(0.166)$ \\
\hline $\begin{array}{l}\text { Occupation } \\
\text { Manag., busin., science, arts } \\
\text { Service } \\
\text { Sales, office } \\
\text { Natural res., constr., maint. } \\
\text { Prod., transp., mat. moving } \\
\text { Military } \\
\text { Unspecified } \\
\text { Unemployed }\end{array}$ & $\begin{array}{r}\text { ref. } \\
0.881 \\
0.789 * * * \\
0.707 * * * \\
0.857 * \\
0.651^{*} \\
0.979 \\
0.895 \\
\end{array}$ & $\begin{array}{r}(0.0683) \\
(0.0511) \\
(0.0686) \\
(0.0728) \\
(0.147) \\
(0.269) \\
(0.120) \\
\end{array}$ & & & & & & \\
\hline $\begin{array}{l}\text { Region of interview } \\
\text { New England } \\
\text { Middle Atlantic } \\
\text { East North Central } \\
\text { West North Central } \\
\text { South Atlantic } \\
\text { East South Central } \\
\text { West South Central } \\
\text { Mountain } \\
\text { Pacific } \\
\end{array}$ & $\begin{array}{r}1.359 * * * \\
1.141 \\
1.225 * * * \\
1.264 * * \\
\text { ref. } \\
1.121 \\
1.126 \\
1.452 * * * \\
1.440 * * *\end{array}$ & $\begin{array}{r}(0.156) \\
(0.111) \\
(0.0902) \\
(0.126) \\
\\
(0.133) \\
(0.105) \\
(0.145) \\
(0.166) \\
\end{array}$ & $1.176^{*}$ & $(0.112)$ & $\begin{array}{r}\text { ref. } \\
1.043\end{array}$ & $(0.118)$ & $\begin{array}{r}\text { ref. } \\
0.874\end{array}$ & $(0.161)$ \\
\hline $\begin{array}{l}\text { Area of residence at age } \mathbf{1 6} \\
\text { Foreign } \\
\text { Country, non-farm } \\
\text { Farm } \\
\text { Town: }<50,000 \\
\text { City: } 50,000 \text { to } 250,000 \\
\text { Big-city suburb } \\
\text { City: }>250,000 \\
\end{array}$ & $\begin{array}{r}3.391 * * * \\
0.891 \\
0.837 * \\
\text { ref. } \\
1.126 \\
1.147 * \\
0.879\end{array}$ & $\begin{array}{l}(0.575) \\
(0.0705) \\
(0.0784) \\
\\
(0.0810) \\
(0.0842) \\
(0.0826)\end{array}$ & $\begin{array}{r}2.680 * * * \\
\text { ref. } \\
1.006\end{array}$ & $\begin{array}{r}(0.301) \\
(0.0821)\end{array}$ & $\begin{array}{r}1.988 * * * \\
\text { ref. } \\
1.212 *\end{array}$ & $\begin{array}{l}(0.251) \\
(0.133) \\
\end{array}$ & $\begin{array}{r}1.706^{* * * *} \\
\text { ref. } \\
1.392^{*}\end{array}$ & $\begin{array}{r}(0.314) \\
\\
(0.249) \\
\end{array}$ \\
\hline $\begin{array}{l}\text { Political party affiliation } \\
\text { Strong democrat } \\
\text { Democrat } \\
\text { Ind., near Dem. } \\
\text { Independent } \\
\text { Ind., near Rep. } \\
\text { Republican } \\
\text { Strong Republican } \\
\text { Other party }\end{array}$ & $\begin{array}{r}1.205^{*} \\
\text { ref. } \\
1.228 * * * \\
0.978 \\
0.705 * * * \\
0.704 * * * \\
0.598 * * * \\
0.916\end{array}$ & $\begin{array}{r}(0.121) \\
(0.0948) \\
(0.0708) \\
(0.0651) \\
(0.0552) \\
(0.0540) \\
(0.178)\end{array}$ & $\begin{array}{r}1.259 * * * \\
\text { ref. } \\
\\
\\
1.147\end{array}$ & $\begin{array}{l}\text { (0.106) } \\
(0.203)\end{array}$ & $\begin{array}{r}1.730 * * * \\
\text { ref. } \\
\\
2.097 * * *\end{array}$ & $\begin{array}{l}(0.179) \\
(0.529)\end{array}$ & $\begin{array}{r}1.587 * * * \\
\text { ref. } \\
\\
\\
1.735\end{array}$ & $\begin{array}{l}(0.214) \\
(0.602)\end{array}$ \\
\hline Constant & $1.980 * * *$ & $(0.220)$ & $0.605 * * *$ & $(0.0680)$ & $0.0672 * * *$ & $(0.00857)$ & $0.0175 * * *$ & $(0.00291)$ \\
\hline Observations & 9,265 & & 9,265 & & 9,265 & & 9,265 & \\
\hline
\end{tabular}

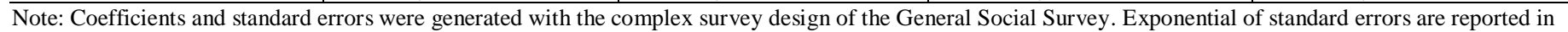

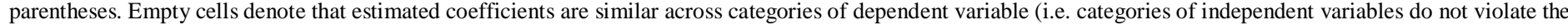
proportional odds/parallel lines assumption). *** Significant at $\mathrm{p}<0.01, * *$ Significant at $\mathrm{p}<0.05, *$ Significant at $\mathrm{p}<0.1$.

Source: 2004, 2008, 2010, 2012, 2014, and 2016 General Social Surveys. 
Table 6. Summary of odds ratios from a generalized ordered logit model predicting opinion about how should the number of immigrants to America be nowadays, including racial resentment, United States, 2004-2016 (model 1 in Table A2)

\begin{tabular}{|c|c|c|c|c|}
\hline Independent variable & $\begin{array}{c}\text { Above } \\
\text { reduced } \\
\text { a lot } \\
\end{array}$ & $\begin{array}{c}\text { Above } \\
\text { reduced } \\
\text { a little } \\
\end{array}$ & $\begin{array}{c}\text { Above } \\
\text { remain } \\
\text { the same }\end{array}$ & $\begin{array}{c}\text { Above } \\
\text { increased } \\
\text { a little } \\
\end{array}$ \\
\hline $\begin{array}{l}\text { Racial resentment } \\
\text { Low } \\
\text { Medium }\end{array}$ & $\begin{array}{r}1.102 \\
(0.0917) \\
\text { ref. }\end{array}$ & $\begin{array}{r}1.212 * * * \\
(0.0846) \\
\text { ref. }\end{array}$ & $\begin{array}{r}1.760 * * * \\
(0.155) \\
\text { ref. }\end{array}$ & $\begin{array}{r}1.710^{* * * *} \\
\text { (0.227) } \\
\text { ref. }\end{array}$ \\
\hline High & $\begin{array}{r}0.444 * * * \\
(0.0389)\end{array}$ & $\begin{array}{r}0.598^{* * * *} \\
(0.0487)\end{array}$ & $\begin{array}{r}0.674 * * * \\
(0.0931)\end{array}$ & $\begin{array}{r}0.677 * \\
(0.148) \\
\end{array}$ \\
\hline Observations & 8,189 & 8,189 & 8,189 & 8,189 \\
\hline
\end{tabular}

Note: Coefficients and standard errors were generated with the complex survey design of the General Social Survey. Exponential of standard errors are reported in parentheses. Empty cells denote that estimated coefficients are similar across categories of dependent variable (i.e. categories of independent variables do not violate the proportional odds/parallel lines assumption). This model is controlled for year, sex, race/ethnicity, age group, education degree, religion, occupation, region of interview, area of residence at age 16, and political party affiliation. *** Significant at $\mathrm{p}<0.01$, ** Significant at $\mathrm{p}<0.05$, * Significant at $\mathrm{p}<0.1$.

Source: 2004, 2008, 2010, 2012, 2014, and 2016 General Social Surveys. 
Table 7. Summary of estimates from ordinary least squares models predicting opinion about how should the number of immigrants to America be nowadays, including racial resentment and economic achievement, United States, 2004-2016 (models 4, 7, and 10 in Table A3)

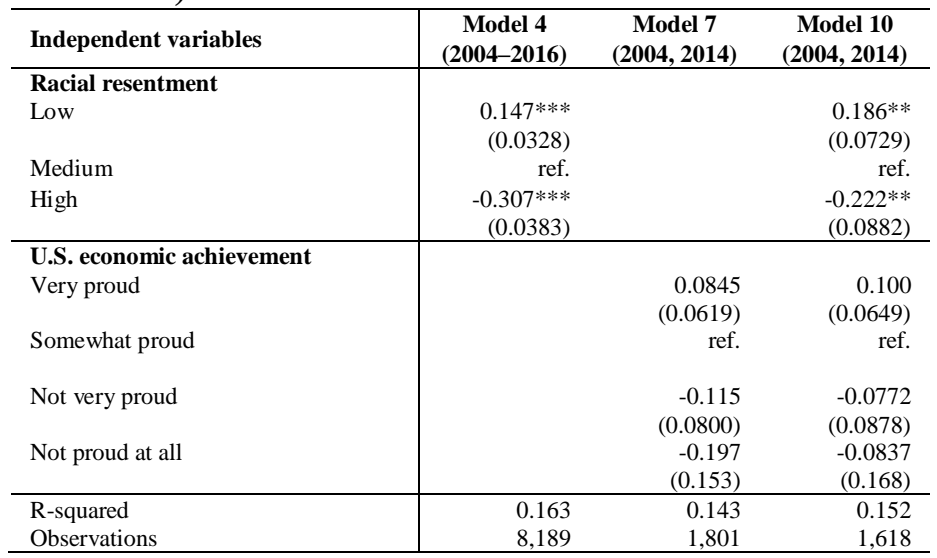

Note: Coefficients and standard errors were generated with the complex survey design of the General Social Survey. Standard errors are reported in parentheses. These models are controlled for year, sex, race/ethnicity, age group, education degree, religion, occupation, region of inter view, area of residence at age 16, and political party affiliation. $* * *$ Significant at $\mathrm{p}<0.01$, ** Significant at $\mathrm{p}<0.05$, $*$ Significant at $\mathrm{p}<0.1$.

Source: 2004, 2008, 2010, 2012, 2014, and 2016 General Social Surveys. 
Table 8. Summary of odds ratios from a generalized ordered logit model predicting opinion about how should the number of immigrants to America be nowadays, including countylevel variables, United States, 2008-2014 (model 1 in Table A4)

\begin{tabular}{|c|c|c|c|c|}
\hline \multirow[b]{2}{*}{ Independent variables } & \multicolumn{4}{|c|}{ Model 1 (political party affiliation) } \\
\hline & $\begin{array}{c}\text { Above } \\
\text { reduced } \\
\text { a lot } \\
\end{array}$ & $\begin{array}{l}\text { Above } \\
\text { reduced } \\
\text { a little }\end{array}$ & $\begin{array}{l}\text { Above } \\
\text { remain } \\
\text { the same }\end{array}$ & $\begin{array}{c}\text { Above } \\
\text { increased } \\
\text { a little } \\
\end{array}$ \\
\hline Prop. of unemployment & $\begin{array}{r}0.790 \\
(0.156) \\
\end{array}$ & & & \\
\hline Prop. of college graduates & $\begin{array}{c}1.407 * \\
(0.270)\end{array}$ & & & \\
\hline Prop. of Protestants/Catholics & $\begin{array}{r}0.710 \\
(0.175) \\
\end{array}$ & & & \\
\hline Prop. of immigrants & $\begin{array}{l}2.187 * \\
(0.947)\end{array}$ & & & \\
\hline Observations & 5,237 & 5,237 & 5,237 & 5,237 \\
\hline
\end{tabular}

Note: Coefficients and standard errors were generated with weight variable from the General Social Survey. Standard errors allow for intragroup correlation (i.e., we specify that observations are independent across counties, but not necessarily within counties). Exponential of standard errors are reported in parentheses. Empty cells denote that estimated coefficients are similar across categories of dependent variable (i.e. categories of independent variables do not violate the proportional odds/parallel lines assumption). This model is controlled for year, sex, race/ethnicity, age group, education degree, religion, occupation, region of interview, area of residence at age 16 , and political party affiliation. $* * *$ Significant at $\mathrm{p}<0.01, * *$ Significant at $\mathrm{p}<0.05, *$ Significant at $\mathrm{p}<0.1$.

Source: 2008, 2010, 2012, and 2014 General Social Surveys and American Community Surveys five-year estimates. 


\section{Appendix A.}

Table A1. Odds ratios from generalized ordered logit models predicting opinion about how should the number of immigrants to America be nowadays, United States, 2004-2016 (complete version of Table 5)

\begin{tabular}{|c|c|c|c|c|c|c|c|c|c|c|c|c|}
\hline \multirow[b]{2}{*}{ Independent variables } & \multicolumn{4}{|c|}{ Model 1 (political party affiliation) } & \multicolumn{4}{|c|}{ Model 2 (political views) } & \multicolumn{4}{|c|}{ Model 3 (political party affiliation \& political views) } \\
\hline & $\begin{array}{c}\text { Above } \\
\text { reduced } \\
\text { a lot }\end{array}$ & $\begin{array}{l}\text { Above } \\
\text { reduced } \\
\text { a little }\end{array}$ & $\begin{array}{l}\text { Above } \\
\text { remain } \\
\text { the same }\end{array}$ & $\begin{array}{c}\text { Above } \\
\text { increased } \\
\text { a little }\end{array}$ & $\begin{array}{c}\text { Above } \\
\text { reduced } \\
\text { a lot }\end{array}$ & $\begin{array}{l}\text { Above } \\
\text { reduced } \\
\text { a little }\end{array}$ & $\begin{array}{l}\text { Above } \\
\text { remain } \\
\text { the same }\end{array}$ & $\begin{array}{c}\text { Above } \\
\text { increased } \\
\text { a little }\end{array}$ & $\begin{array}{l}\text { Above } \\
\text { reduced } \\
\text { a lot }\end{array}$ & $\begin{array}{l}\text { Above } \\
\text { reduced } \\
\text { a little }\end{array}$ & $\begin{array}{l}\text { Above } \\
\text { remain } \\
\text { the same }\end{array}$ & $\begin{array}{c}\text { Above } \\
\text { increased } \\
\text { a little }\end{array}$ \\
\hline $\begin{array}{l}\text { Year } \\
2004\end{array}$ & ref. & & & & ref. & & & & ref. & & & \\
\hline 2008 & 0.942 & & & & 1.024 & & & & 0.998 & & & \\
\hline & $(0.0775)$ & & & & $(0.100)$ & & & & $(0.0985)$ & & & \\
\hline 2010 & 1.074 & & & & 1.150 & & & & 1.137 & & & \\
\hline & $(0.0919)$ & & & & $(0.114)$ & & & & $(0.114)$ & & & \\
\hline 2012 & $1.206^{* * *}$ & & & & $1.287^{* *}$ & & & & $1.271 * *$ & & & \\
\hline & $(0.106)$ & & & & $(0.130)$ & & & & $(0.131)$ & & & \\
\hline 2014 & $1.244 * * * *$ & & & & $1.318^{* * * *}$ & & & & $1.304 * * *$ & & & \\
\hline 2016 & $\begin{array}{r}(0.102) \\
1.526 * * *\end{array}$ & & & & $\begin{array}{r}(0.129) \\
1.602 * * *\end{array}$ & & & & $\begin{array}{r}(0.128) \\
596 * * * *\end{array}$ & & & \\
\hline & $(0.117)$ & & & & $(0.146)$ & & & & $(0.148)$ & & & \\
\hline $\begin{array}{l}\text { Sex } \\
\text { Female }\end{array}$ & ref. & & & & ref. & & & & ref. & & & \\
\hline Male & $\begin{array}{r}1.047 \\
(0.0488) \\
\end{array}$ & & & & $\begin{array}{r}1.034 \\
(0.0520) \\
\end{array}$ & & & & $\begin{array}{r}1.054 \\
(0.0537) \\
\end{array}$ & & & \\
\hline $\begin{array}{l}\text { Race/ethnicity } \\
\text { White }\end{array}$ & ref. & ref. & ref. & ref. & ref. & ref. & ref. & ref. & ref. & ref. & ref. & ref. \\
\hline Black & $\begin{array}{r}1.497 * * * \\
(0.146)\end{array}$ & $\begin{array}{r}1.455^{* * *} \\
(0.119)\end{array}$ & $\begin{array}{r}1.534 * * * * \\
(0.179)\end{array}$ & $\begin{array}{r}2.395^{* * * *} \\
(0.451)\end{array}$ & $\begin{array}{r}1.765^{* * * *} \\
(0.143)\end{array}$ & & & & $\begin{array}{r}1.527 * * * * \\
(0.126)\end{array}$ & & & \\
\hline Hispanic & $\begin{array}{r}2.126^{* * * *} \\
(0.294)\end{array}$ & $\begin{array}{r}2.169 * * * * \\
(0.214)\end{array}$ & $\begin{array}{r}1.739 * * * * \\
(0.208)\end{array}$ & $\begin{array}{r}3.113^{* * *} \\
(0.584)\end{array}$ & $\begin{array}{r}2.430 * * * * \\
(0.361)\end{array}$ & $\begin{array}{r}2.425^{* * *} \\
(0.264)\end{array}$ & $\begin{array}{r}1.595 * * * \\
(0.205)\end{array}$ & $\begin{array}{r}2.573 * * * \\
(0.432)\end{array}$ & $\begin{array}{r}2.300 * * * * \\
(0.344)\end{array}$ & $\begin{array}{r}2.295^{* * * *} \\
(0.255)\end{array}$ & $\begin{array}{r}1.507 * * * * \\
(0.197)\end{array}$ & $\begin{array}{r}2.439 * * * \\
(0.413)\end{array}$ \\
\hline Other & $\begin{array}{r}1.904 * * * * \\
(0.372) \\
\end{array}$ & $\begin{array}{r}1.990^{* * * *} \\
(0.316) \\
\end{array}$ & $\begin{array}{r}1.339^{*} \\
(0.228) \\
\end{array}$ & $\begin{array}{r}2.566^{* * * *} \\
(0.579) \\
\end{array}$ & $\begin{array}{r}2.246 * * * * \\
(0.475) \\
\end{array}$ & $\begin{array}{r}2.189 * * * \\
(0.365) \\
\end{array}$ & $\begin{array}{r}1.393^{*} \\
(0.248) \\
\end{array}$ & $\begin{array}{r}2.481^{* * * *} \\
(0.569) \\
\end{array}$ & $\begin{array}{r}2.211 * * * \\
(0.479) \\
\end{array}$ & $\begin{array}{r}2.166 * * * * \\
(0.370) \\
\end{array}$ & $\begin{array}{r}1.379^{*} \\
(0.246) \\
\end{array}$ & $\begin{array}{r}2.466 * * * \\
(0.564) \\
\end{array}$ \\
\hline Age group & & & & & & & & & & & & \\
\hline $\begin{array}{l}18-24 \\
25-44\end{array}$ & $\begin{array}{r}1.628^{* * * *} \\
\text { (0.186) } \\
\text { ref. }\end{array}$ & $\begin{array}{r}1.216^{* *} \\
(0.117) \\
\text { ref. }\end{array}$ & $\begin{array}{r}1.347 * * * * \\
(0.142) \\
\text { ref. }\end{array}$ & $\begin{array}{r}0.965 \\
(0.187) \\
\text { ref. }\end{array}$ & $\begin{array}{r}1.254 * * \\
(0.116) \\
\text { ref. }\end{array}$ & & & & $\begin{array}{r}1.270^{* *} \\
(0.118) \\
\text { ref. }\end{array}$ & & & \\
\hline $\begin{array}{l}45-64 \\
65-89\end{array}$ & $\begin{array}{r}0.780^{* * *} * \\
(0.0442) \\
0.875 * \\
(0.0614) \\
\end{array}$ & & & & $\begin{array}{r}0.790^{* * * *} \\
(0.0491) \\
0.883 \\
(0.0683) \\
\end{array}$ & & & & $\begin{array}{r}0.786 * * * \\
(0.0489) \\
0.863^{*} \\
(0.0662) \\
\end{array}$ & & & \\
\hline Education degree & & & & & & & & & & & & \\
\hline $\begin{array}{l}\text { Less than high school } \\
\text { High school }\end{array}$ & $\begin{array}{r}0.731 * * * \\
(0.0608) \\
\text { ref. }\end{array}$ & $\begin{array}{r}0.854 * * \\
(0.0678) \\
\text { ref. }\end{array}$ & $\begin{array}{r}1.434 * * * \\
\text { (0.162) } \\
\text { ref. }\end{array}$ & $\begin{array}{c}1.732 * * * \\
(0.286) \\
\text { ref. }\end{array}$ & $\begin{array}{r}0.819 * * \\
(0.0774) \\
\text { ref. }\end{array}$ & $\begin{array}{r}0.857^{*} \\
(0.0748) \\
\text { ref. }\end{array}$ & $\begin{array}{r}1.418^{* * *} \\
(0.173) \\
\text { ref. }\end{array}$ & $\begin{array}{r}1.865^{* * * *} \\
(0.332) \\
\text { ref. }\end{array}$ & $\begin{array}{r}0.799 * * \\
(0.0753) \\
\text { ref. }\end{array}$ & $\begin{array}{r}0.839 * * \\
(0.0723) \\
\text { ref. }\end{array}$ & $\begin{array}{r}1.388 * * * \\
(0.171) \\
\text { ref. }\end{array}$ & $\begin{array}{r}1.825 * * * \\
(0.328) \\
\text { ref. }\end{array}$ \\
\hline Junior college & $\begin{array}{r}1.074 \\
(0.0918)\end{array}$ & & & & $\begin{array}{r}1.046 \\
(0.0965)\end{array}$ & & & & $\begin{array}{r}1.052 \\
(0.0999)\end{array}$ & & & \\
\hline Bachelor & $\begin{array}{r}2.103 * * * * \\
(0.194)\end{array}$ & $\begin{array}{r}1.648^{* * * *} \\
(0.124)\end{array}$ & $\begin{array}{r}1.582^{* * * *} \\
(0.153)\end{array}$ & $\begin{array}{r}1.062 \\
(0.177)\end{array}$ & $\begin{array}{r}1.931 * * * * \\
(0.190)\end{array}$ & $\begin{array}{r}1.587 * * * * \\
(0.131)\end{array}$ & $\begin{array}{r}1.488^{* * * *} \\
(0.161)\end{array}$ & $\begin{array}{r}0.989 \\
(0.181)\end{array}$ & $\begin{array}{r}1.965 * * * \\
(0.193)\end{array}$ & $\begin{array}{r}1.612 * * * * \\
(0.134)\end{array}$ & $\begin{array}{r}1.496 * * * * \\
(0.162)\end{array}$ & $\begin{array}{r}0.986 \\
(0.181)\end{array}$ \\
\hline Graduate & $\begin{array}{r}2.335 \text { **** } \\
(0.307)\end{array}$ & $\begin{array}{r}2.128^{* * * *} \\
(0.209)\end{array}$ & $\begin{array}{r}2.266 * * * * \\
(0.279)\end{array}$ & $\begin{array}{l}1.392 * \\
(0.271)\end{array}$ & $\begin{array}{r}2.126 * * * * \\
(0.296)\end{array}$ & $\begin{array}{r}1.921 * * * \\
(0.205)\end{array}$ & $\begin{array}{r}2.040 * * * * \\
(0.270)\end{array}$ & $\begin{array}{r}1.007 \\
(0.207)\end{array}$ & $\begin{array}{r}2.160 * * * \\
(0.299)\end{array}$ & $\begin{array}{r}1.940 * * * * \\
(0.207)\end{array}$ & $\begin{array}{r}2.041 * * * * \\
(0.272)\end{array}$ & $\begin{array}{r}1.002 \\
(0.208)\end{array}$ \\
\hline
\end{tabular}




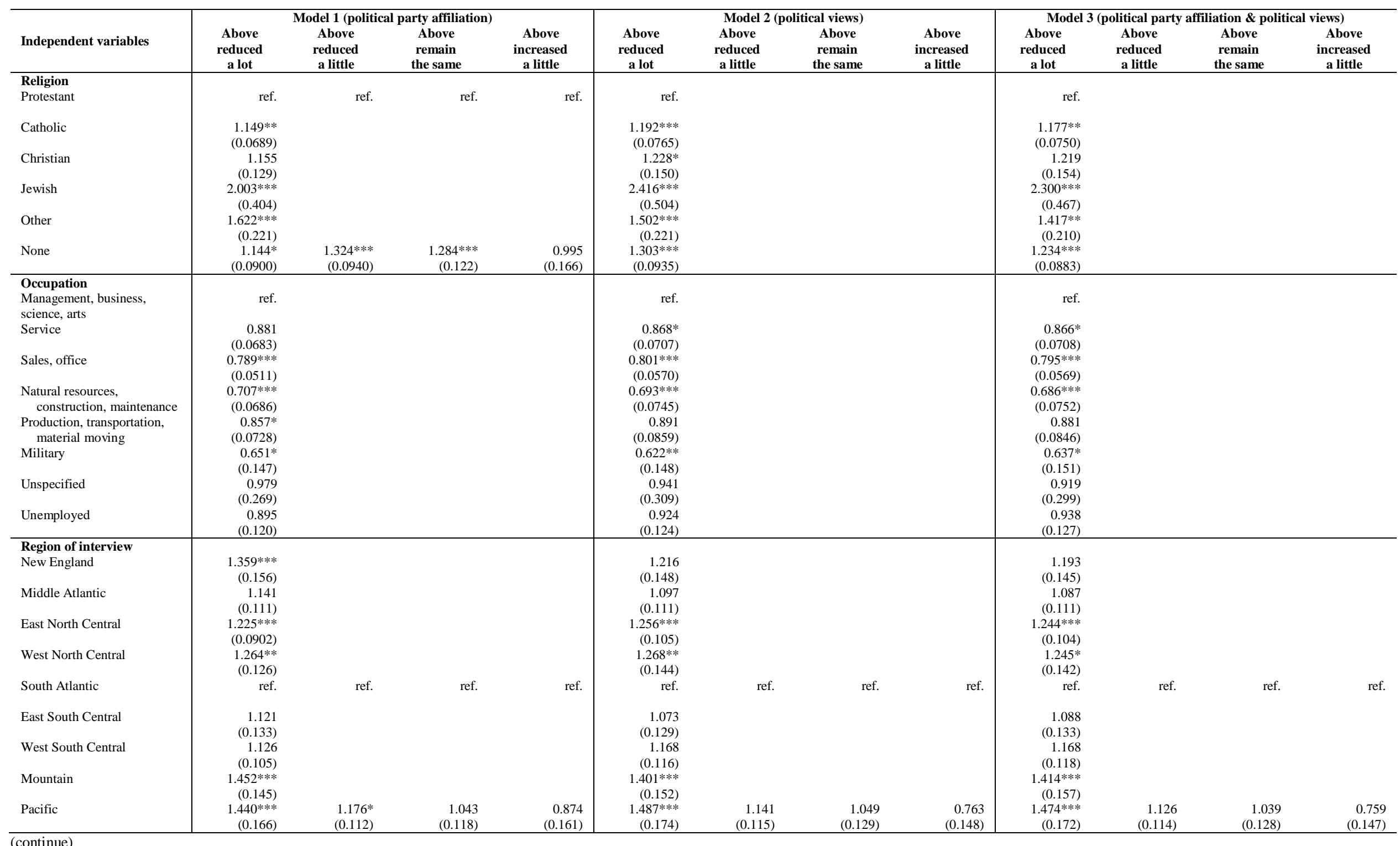




\begin{tabular}{|c|c|c|c|c|c|c|c|c|c|c|c|c|}
\hline \multirow[b]{2}{*}{ Independent variables } & \multicolumn{4}{|c|}{ Model 1 (political party affiliation) } & \multicolumn{4}{|c|}{ Model 2 (political views) } & \multicolumn{4}{|c|}{ Model 3 (political party affiliation \& political views) } \\
\hline & $\begin{array}{c}\text { Above } \\
\text { reduced } \\
\text { a lot }\end{array}$ & $\begin{array}{c}\text { Above } \\
\text { reduced } \\
\text { a little }\end{array}$ & $\begin{array}{c}\text { Above } \\
\text { remain } \\
\text { the same }\end{array}$ & $\begin{array}{c}\text { Above } \\
\text { increased } \\
\text { a little }\end{array}$ & $\begin{array}{c}\text { Above } \\
\text { reduced } \\
\text { a lot }\end{array}$ & $\begin{array}{c}\text { Above } \\
\text { reduced } \\
\text { a little }\end{array}$ & $\begin{array}{c}\text { Above } \\
\text { remain } \\
\text { the same }\end{array}$ & $\begin{array}{c}\text { Above } \\
\text { increased } \\
\text { a little } \\
\end{array}$ & $\begin{array}{c}\text { Above } \\
\text { reduced } \\
\text { a lot }\end{array}$ & $\begin{array}{l}\text { Above } \\
\text { reduced } \\
\text { a little }\end{array}$ & $\begin{array}{l}\text { Above } \\
\text { remain } \\
\text { the same }\end{array}$ & $\begin{array}{c}\text { Above } \\
\text { increased } \\
\text { a little }\end{array}$ \\
\hline \multirow{2}{*}{$\begin{array}{l}\text { Area of residence at age } 16 \\
\text { Foreign }\end{array}$} & & & & & & & & & & & & \\
\hline & $\begin{array}{r}3.390 .575) \\
(0.575)\end{array}$ & $\begin{array}{r}(0.301) \\
(0.301)\end{array}$ & $\begin{array}{r}1.988 \\
(0.251)\end{array}$ & $\begin{array}{r}1 . / 06.314) \\
(0.314)\end{array}$ & $\begin{array}{r}2.237 \\
(0.229)\end{array}$ & & & & $\begin{array}{r}2.219 \\
(0.228)\end{array}$ & & & \\
\hline \multirow{2}{*}{ Country, non-farm } & 0.891 & & & & 0.908 & & & & 0.923 & & & \\
\hline & $(0.0705)$ & & & & $(0.0814)$ & & & & $(0.0838)$ & & & \\
\hline Farm & $\begin{array}{r}0.837^{*} \\
(0.0784)\end{array}$ & & & & $\begin{array}{r}0.869 \\
(0.0904)\end{array}$ & & & & $\begin{array}{r}0.889 \\
(0.0929)\end{array}$ & & & \\
\hline Town: $<50,000$ & ref. & ref. & ref. & ref. & ref. & ref. & ref. & ref. & ref. & ref. & ref. & ref. \\
\hline City: 50,000 to 250,000 & $\begin{array}{r}1.126 \\
(0.0810)\end{array}$ & & & & $\begin{array}{r}1.119 \\
(0.0886)\end{array}$ & & & & $\begin{array}{r}1.136 \\
(0.0905)\end{array}$ & & & \\
\hline \multirow[t]{2}{*}{ Big-city suburb } & $1.147^{*}$ & & & & $1.184 * *$ & & & & $1.205^{* *}$ & & & \\
\hline & $\begin{array}{r}(0.0842) \\
0.879\end{array}$ & & & & $(0.0976)$ & & & & $(0.100)$ & & & \\
\hline City: > 250,000 & $\begin{array}{r}0.879 \\
(0.0826) \\
\end{array}$ & $\begin{array}{r}1.006 \\
(0.0821) \\
\end{array}$ & $\begin{array}{l}1.212 * \\
(0.133)\end{array}$ & $\begin{array}{l}1.392^{*} \\
(0.249) \\
\end{array}$ & $\begin{array}{r}0.869 \\
(0.0886) \\
\end{array}$ & $\begin{array}{r}0.991 \\
(0.0851) \\
\end{array}$ & $\begin{array}{r}1.262^{* *} \\
(0.147) \\
\end{array}$ & $\begin{array}{r}1.754 * * * * \\
(0.294) \\
\end{array}$ & $\begin{array}{r}0.869 \\
(0.0887) \\
\end{array}$ & $\begin{array}{r}0.989 \\
(0.0854) \\
\end{array}$ & $\begin{array}{l}1.256^{*} \\
(0.146) \\
\end{array}$ & $\begin{array}{r}1.748 * * * \\
(0.294) \\
\end{array}$ \\
\hline \multirow{2}{*}{$\begin{array}{l}\text { Political party affiliation } \\
\text { Strong democrat }\end{array}$} & & & & & & & & & & & & \\
\hline & $\begin{array}{l}1.205^{*} \\
(0.121)\end{array}$ & $\begin{array}{r}1.259 * * * * \\
(0.106)\end{array}$ & $\begin{array}{r}1.730^{* * * *} \\
(0.179)\end{array}$ & $\begin{array}{r}1.587 * * * \\
(0.214)\end{array}$ & & & & & $\begin{array}{l}1.184 * \\
(0.105)\end{array}$ & & & \\
\hline Democrat & ref. & ref. & ref. & ref. & & & & & ref. & & & \\
\hline Ind., near Dem. & $\begin{array}{r}1.228 * * * \\
(0.0948)\end{array}$ & & & & & & & & $\begin{array}{r}1.135 \\
(0.0922)\end{array}$ & & & \\
\hline Independent & $\begin{array}{r}0.978 \\
(0.0708)\end{array}$ & & & & & & & & 1.005 & & & \\
\hline \multirow{2}{*}{ Ind., near Rep. } & $0.705 * * * 3$ & & & & & & & & $(0.0783)$ & & & \\
\hline & $\begin{array}{r}0.705^{* * * * *} \\
(0.0651)\end{array}$ & & & & & & & & $\begin{array}{r}0.699^{* * * *} \\
(0.0720)\end{array}$ & & & \\
\hline \multirow[t]{2}{*}{ Republican } & $0.704 * * *$ & & & & & & & & $0.765 * * *$ & & & \\
\hline & $(0.0552)$ & & & & & & & & $(0.0716)$ & & & \\
\hline \multirow[t]{2}{*}{ Strong Republican } & $\begin{array}{r}0.598 * * * \\
(0.0540)\end{array}$ & & & & & & & & $\begin{array}{r}0.677 * * * \\
(0.0754)\end{array}$ & & & \\
\hline & $(0.0540)$ & & & & & & & & $(0.0754)$ & & & \\
\hline Other party & $\begin{array}{r}0.916 \\
(0.178)\end{array}$ & $\begin{array}{r}1.147 \\
(0.203) \\
\end{array}$ & $\begin{array}{r}2.097 * * * * \\
(0.529) \\
\end{array}$ & $\begin{array}{r}1.735 \\
(0.602)\end{array}$ & & & & & $\begin{array}{r}1.252 \\
(0.254)\end{array}$ & & & \\
\hline \multirow{2}{*}{$\begin{array}{l}\text { Political views } \\
\text { Extremely liberal }\end{array}$} & & & & & & & & & & & & \\
\hline & & & & & $\begin{array}{r}1.148 \\
(0.203)\end{array}$ & $\begin{array}{r}2.179 * * * * \\
(0.342)\end{array}$ & $\begin{array}{r}3.065^{* * * *} \\
(0.449)\end{array}$ & $\begin{array}{r}4.296 * * * \\
(0.875)\end{array}$ & $\begin{array}{r}1.052 \\
(0.187)\end{array}$ & $\begin{array}{r}1.986^{* * * *} \\
(0.306)\end{array}$ & $\begin{array}{r}2.748 * * * \\
(0.402)\end{array}$ & $\begin{array}{r}3.850^{* * * *} \\
(0.795)\end{array}$ \\
\hline Liberal & & & & & $\begin{array}{r}1.928 * * * \\
(0.173)\end{array}$ & & & & $\begin{array}{r}1.755^{* * * *} \\
(0.162)\end{array}$ & & & \\
\hline Slightly liberal & & & & & $\begin{array}{r}1.331 * * * \\
(0.113)\end{array}$ & & & & $\begin{array}{r}1.256^{* * * *} \\
(0.108)\end{array}$ & & & \\
\hline Moderate & & & & & ref. & ref. & ref. & ref. & ref. & ref. & ref. & ref. \\
\hline Slightly conservative & & & & & $\begin{array}{r}1.157 \\
(0.117)\end{array}$ & $\begin{array}{r}0.913 \\
(0.0748)\end{array}$ & $\begin{array}{r}0.928 \\
(0.122)\end{array}$ & $\begin{array}{r}0.632 * * \\
(0.141)\end{array}$ & $\begin{array}{r}1.271 * * \\
(0.132)\end{array}$ & $\begin{array}{r}1.005 \\
(0.0862)\end{array}$ & $\begin{array}{r}1.021 \\
(0.139)\end{array}$ & $\begin{array}{r}0.693 \\
(0.155)\end{array}$ \\
\hline \multirow[t]{2}{*}{ Conservative } & & & & & $0.789^{* * * *}$ & & & & 0.931 & & & \\
\hline & & & & & $(0.0571)$ & & & & $(0.0764)$ & & & \\
\hline Extremely conservative & & & & & $\begin{array}{r}0.492 * * * \\
(0.0780)\end{array}$ & $\begin{array}{l}0.726^{*} \\
(0.120)\end{array}$ & $\begin{array}{r}1.149 \\
(0.322)\end{array}$ & $\begin{array}{r}0.951 \\
(0.331)\end{array}$ & $\begin{array}{r}0.564 * * * \\
(0.0914)\end{array}$ & $\begin{array}{r}0.834 \\
(0.143)\end{array}$ & $\begin{array}{r}1.302 \\
(0.371)\end{array}$ & $\begin{array}{r}1.069 \\
(0.380)\end{array}$ \\
\hline \multirow[t]{2}{*}{ Constant } & $1.980 * * *$ & $0.605^{* * *}$ & $0.0672 * * *$ & $0.0175^{* * *}$ & $1.545 * * *$ & $0.489 * * *$ & $0.0565 * * *$ & $0.0137^{* * * *}$ & $1.703 * * *$ & $0.535 * * *$ & $0.0614 * * *$ & $0.0149 * * *$ \\
\hline & $(0.220)$ & $(0.0680)$ & $(0.00857)$ & $(0.00291)$ & $(0.190)$ & $(0.0605)$ & $(0.00757)$ & $(0.00222)$ & $(0.223)$ & $(0.0705)$ & $(0.00873)$ & $(0.00260)$ \\
\hline Observations & 9,265 & 9,265 & 9,265 & 9,265 & 7,925 & 7,925 & 7,925 & 7,925 & 7,925 & 7,925 & 7,925 & 7,925 \\
\hline
\end{tabular}

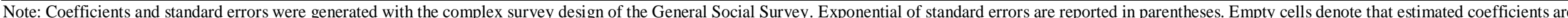

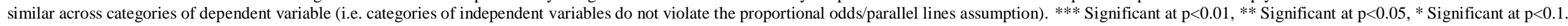

Source: 2004, 2008, 2010, 2012, 2014, and 2016 General Social Surveys. 
Table A2. Odds ratios from generalized ordered logit models predicting opinion about how should the number of immigrants to America be nowadays, including racial resentment variable, United States, 2004-2016 (complete version of Table 6)

\begin{tabular}{|c|c|c|c|c|c|c|c|c|c|c|c|c|}
\hline \multirow[b]{2}{*}{ Independent variables } & \multicolumn{4}{|c|}{ Model 1 (political party affiliation) } & \multicolumn{4}{|c|}{ Model 2 (political views) } & \multicolumn{4}{|c|}{ Model 3 (political party affiliation \& political views) } \\
\hline & $\begin{array}{c}\text { Above } \\
\text { reduced } \\
\text { a lot }\end{array}$ & $\begin{array}{c}\text { Above } \\
\text { reduced } \\
\text { a little }\end{array}$ & $\begin{array}{l}\text { Above } \\
\text { remain } \\
\text { the same }\end{array}$ & $\begin{array}{c}\text { Above } \\
\text { increased } \\
\text { a little } \\
\end{array}$ & $\begin{array}{c}\text { Above } \\
\text { reduced } \\
\text { a lot }\end{array}$ & $\begin{array}{l}\text { Above } \\
\text { reduced } \\
\text { a little }\end{array}$ & $\begin{array}{l}\text { Above } \\
\text { remain } \\
\text { the same }\end{array}$ & $\begin{array}{c}\text { Above } \\
\text { increased } \\
\text { a little } \\
\end{array}$ & $\begin{array}{c}\text { Above } \\
\text { reduced } \\
\text { a lot }\end{array}$ & $\begin{array}{l}\text { Above } \\
\text { reduced } \\
\text { a little }\end{array}$ & $\begin{array}{l}\text { Above } \\
\text { remain } \\
\text { the same }\end{array}$ & $\begin{array}{c}\text { Above } \\
\text { increased } \\
\text { a little }\end{array}$ \\
\hline $\begin{array}{l}\text { Year } \\
2004\end{array}$ & ref. & & & & ref. & & & & ref. & & & \\
\hline 2008 & $\begin{array}{r}0.924 \\
(0.0835)\end{array}$ & & & & $\begin{array}{r}0.980 \\
(0.109)\end{array}$ & & & & $\begin{array}{r}0.962 \\
(0.107)\end{array}$ & & & \\
\hline 2010 & $\begin{array}{r}1.121 \\
(0.104)\end{array}$ & & & & $\begin{array}{r}1.177 \\
(0.132)\end{array}$ & & & & $\begin{array}{l}1.161 \\
(0.130)\end{array}$ & & & \\
\hline 2012 & $1.191^{*}$ & & & & $1.253^{* *}$ & & & & $1.229^{*}$ & & & \\
\hline 2014 & $1.240^{* * * *}$ & & & & $\begin{array}{l}(0.138) \\
1.303^{* *}\end{array}$ & & & & $\begin{array}{r}(0.136) \\
1.286^{* * *}\end{array}$ & & & \\
\hline & $(0.102)$ & & & & $(0.134)$ & & & & $(0.133)$ & & & \\
\hline 2016 & $\begin{array}{r}1.470 * * * \\
(0.117)\end{array}$ & & & & $\begin{array}{r}1.521 * * * \\
(0.152)\end{array}$ & & & & $\begin{array}{r}1.517 * * * \\
(0.152) \\
\end{array}$ & & & \\
\hline $\begin{array}{l}\text { Sex } \\
\text { Female }\end{array}$ & ref. & & & & ref. & & & & ref. & & & \\
\hline Male & $\begin{array}{r}1.059 \\
(0.0530) \\
\end{array}$ & & & & $\begin{array}{r}1.058 \\
(0.0589) \\
\end{array}$ & & & & $\begin{array}{r}1.071 \\
(0.0604) \\
\end{array}$ & & & \\
\hline $\begin{array}{l}\text { Race/ethnicity } \\
\text { White }\end{array}$ & ref. & ref. & ref. & ref. & ref. & ref. & ref. & ref. & ref. & ref. & ref. & ref. \\
\hline Black & $\begin{array}{r}1.173 \\
(0.120)\end{array}$ & $\begin{array}{r}1.270 * * * \\
(0.111)\end{array}$ & $\begin{array}{r}1.387 * * * \\
(0.168)\end{array}$ & $\begin{array}{r}2.412^{* * * *} \\
(0.455)\end{array}$ & $\begin{array}{r}1.383^{* * * *} \\
(0.154)\end{array}$ & $\begin{array}{r}1.514 * * * \\
(0.143)\end{array}$ & $\begin{array}{r}1.565^{* * *} \\
(0.206)\end{array}$ & $\begin{array}{r}2.857 * * * * \\
(0.526)\end{array}$ & $\begin{array}{r}1.250^{* *} \\
(0.142)\end{array}$ & $\begin{array}{r}1.377^{* * * *} \\
(0.133)\end{array}$ & $\begin{array}{r}1.442 * * * * \\
(0.190)\end{array}$ & $\begin{array}{r}2.648 * * * \\
(0.488)\end{array}$ \\
\hline Hispanic & $\begin{array}{r}2.072 * * * \\
(0.316)\end{array}$ & $\begin{array}{r}2.191 * * * \\
(0.240)\end{array}$ & $\begin{array}{r}1.901^{* * * *} \\
(0.246)\end{array}$ & $\begin{array}{r}3.879 * * * * \\
(0.730)\end{array}$ & $\begin{array}{r}2.199 * * * \\
(0.365)\end{array}$ & $\begin{array}{r}2.312 * * * \\
(0.284)\end{array}$ & $\begin{array}{r}1.949 * * * \\
(0.281)\end{array}$ & $\begin{array}{r}4.008 * * * * \\
(0.806)\end{array}$ & $\begin{array}{r}2.108 * * * \\
(0.349)\end{array}$ & $\begin{array}{r}2.219 * * * \\
(0.275)\end{array}$ & $\begin{array}{r}1.879 * * * \\
(0.273)\end{array}$ & $\begin{array}{r}3.888 * * * \\
(0.785)\end{array}$ \\
\hline Other & $\begin{array}{r}1.980 * * * * \\
(0.436) \\
\end{array}$ & $\begin{array}{r}1.951^{* * * *} \\
(0.319) \\
\end{array}$ & $\begin{array}{r}1.348^{*} \\
(0.236) \\
\end{array}$ & $\begin{array}{r}2.291 * * * * \\
(0.554) \\
\end{array}$ & $\begin{array}{r}1.827 * * * \\
(0.251) \\
\end{array}$ & & & & $\begin{array}{r}1.798 * * * \\
(0.247) \\
\end{array}$ & & & \\
\hline $\begin{array}{l}\text { Age group } \\
18-24\end{array}$ & $\begin{array}{r}1.627^{* * * *} \\
(0.204)\end{array}$ & $\begin{array}{l}1.206^{*} \\
(0.129)\end{array}$ & $\begin{array}{l}1.245^{*} \\
(0.139)\end{array}$ & $\begin{array}{r}0.902 \\
(0.180)\end{array}$ & $\begin{array}{r}1.229 * * \\
(0.120)\end{array}$ & & & & $\begin{array}{r}1.242 * * \\
(0.121)\end{array}$ & & & \\
\hline $25-44$ & ref. & ref. & ref. & ref. & ref. & ref. & ref. & ref. & ref. & ref. & ref. & ref. \\
\hline $45-64$ & $\begin{array}{r}0.789 * * * \\
(0.0493)\end{array}$ & & & & $\begin{array}{r}0.799^{* * * *} \\
(0.0538)\end{array}$ & & & & $\begin{array}{r}0.798 * * * * \\
(0.0540)\end{array}$ & & & \\
\hline $65-89$ & $\begin{array}{l}0.823 * * \\
(0.0725) \\
\end{array}$ & $\begin{array}{r}0.900 \\
(0.0735) \\
\end{array}$ & $\begin{array}{r}1.130 \\
(0.122)\end{array}$ & $\begin{array}{r}0.950 \\
(0.170)\end{array}$ & $\begin{array}{l}0.824 * * \\
(0.0788)\end{array}$ & $\begin{array}{r}0.917 \\
(0.0803) \\
\end{array}$ & $\begin{array}{r}1.170 \\
(0.139)\end{array}$ & $\begin{array}{r}1.044 \\
(0.203)\end{array}$ & $\begin{array}{r}0.814 * * \\
(0.0776) \\
\end{array}$ & $\begin{array}{r}0.903 \\
(0.0790) \\
\end{array}$ & $\begin{array}{r}1.151 \\
(0.137) \\
\end{array}$ & $\begin{array}{r}1.026 \\
(0.201) \\
\end{array}$ \\
\hline Education degree & & & & & & & & & & & & \\
\hline $\begin{array}{l}\text { Less than high school } \\
\text { High school }\end{array}$ & $\begin{array}{r}0.742 * * * \\
(0.0655) \\
\text { ref. }\end{array}$ & $\begin{array}{r}0.849^{*} \\
(0.0719) \\
\text { ref. }\end{array}$ & $\begin{array}{r}1.399 * * * \\
(0.169) \\
\text { ref. }\end{array}$ & $\begin{array}{r}1.888^{* * * *} \\
(0.326) \\
\text { ref. }\end{array}$ & $\begin{array}{r}0.808^{* *} \\
(0.0803) \\
\text { ref. }\end{array}$ & $\begin{array}{r}0.873 \\
(0.0814) \\
\text { ref. }\end{array}$ & $\begin{array}{r}1.475^{* * * *} \\
(0.186) \\
\text { ref. }\end{array}$ & $\begin{array}{r}2.226 * * * \\
(0.403) \\
\text { ref. }\end{array}$ & $\begin{array}{l}0.792 * * \\
(0.0786) \\
\text { ref. }\end{array}$ & $\begin{array}{r}0.856^{*} \\
(0.0793) \\
\text { ref. }\end{array}$ & $\begin{array}{r}1.442 * * * \\
\text { (0.183) } \\
\text { ref. }\end{array}$ & $\begin{array}{r}2.179 * * * \\
(0.399) \\
\text { ref. }\end{array}$ \\
\hline Junior college & $\begin{array}{r}1.014 \\
(0.0895)\end{array}$ & & & & $\begin{array}{r}1.010 \\
(0.101)\end{array}$ & & & & $\begin{array}{r}1.010 \\
(0.101)\end{array}$ & & & \\
\hline Bachelor & $\begin{array}{r}1.929 * * * \\
(0.195)\end{array}$ & $\begin{array}{r}1.621 * * * \\
(0.131)\end{array}$ & $\begin{array}{r}1.565 * * * \\
(0.161)\end{array}$ & $\begin{array}{r}1.160 \\
(0.215)\end{array}$ & $\begin{array}{r}1.583 * * * \\
(0.125)\end{array}$ & & & & $\begin{array}{r}1.598^{* * * *} \\
(0.127)\end{array}$ & & & \\
\hline Graduate & $\begin{array}{r}2.003 * * * * \\
(0.186)\end{array}$ & & & & $\begin{array}{r}1.822 * * * \\
(0.189)\end{array}$ & & & & $\begin{array}{r}1.841 * * * \\
(0.191)\end{array}$ & & & \\
\hline
\end{tabular}

(continue) 


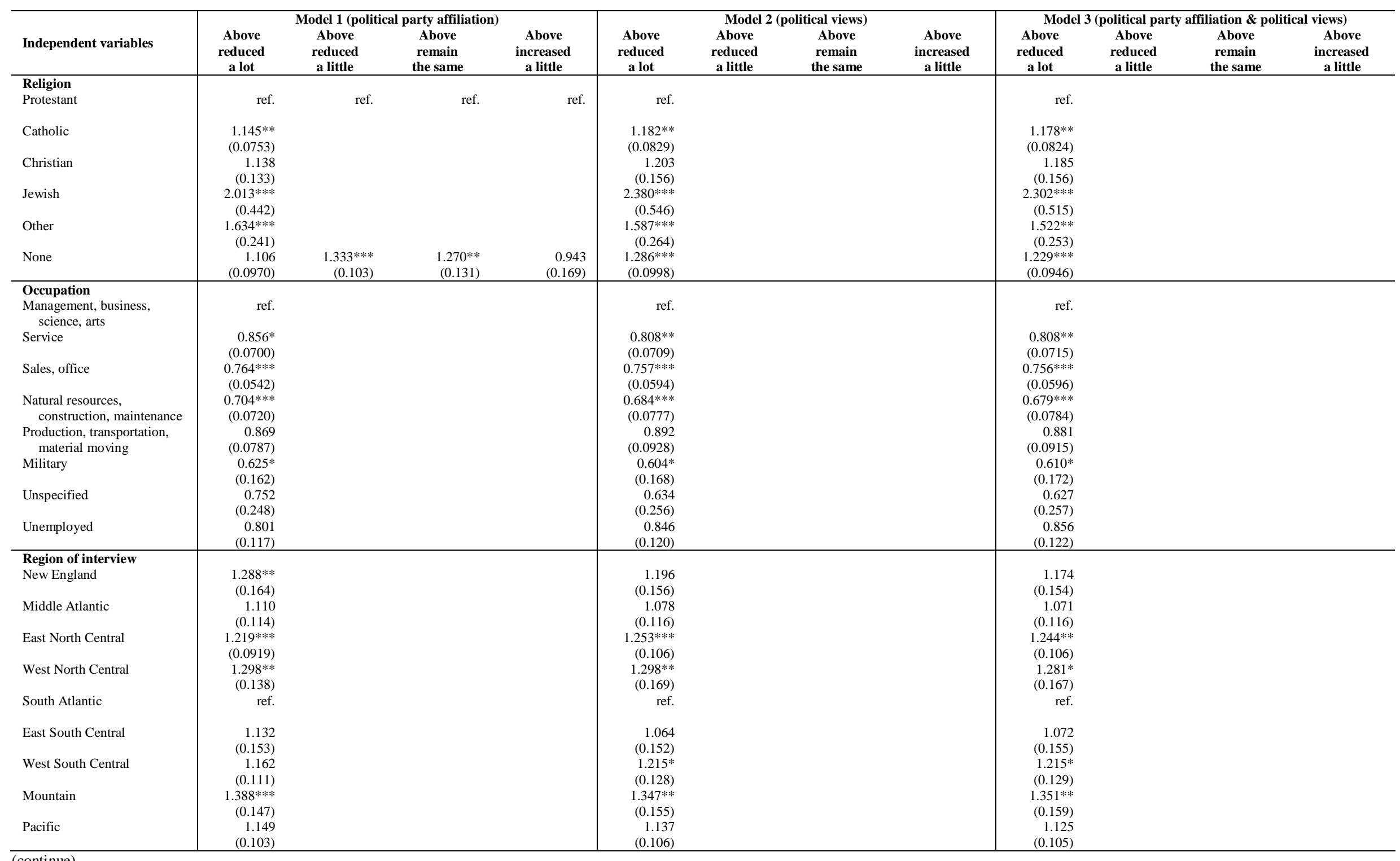




\begin{tabular}{|c|c|c|c|c|c|c|c|c|c|c|c|c|}
\hline \multirow[b]{2}{*}{ Independent variables } & \multicolumn{4}{|c|}{ Model 1 (political party affiliation) } & \multicolumn{4}{|c|}{ Model 2 (political views) } & \multicolumn{4}{|c|}{ Model 3 (political party affiliation \& political views) } \\
\hline & $\begin{array}{c}\text { Above } \\
\text { reduced } \\
\text { a lot }\end{array}$ & $\begin{array}{c}\text { Above } \\
\text { reduced } \\
\text { a little }\end{array}$ & $\begin{array}{l}\text { Above } \\
\text { remain } \\
\text { the same }\end{array}$ & $\begin{array}{c}\text { Above } \\
\text { increased } \\
\text { a little }\end{array}$ & $\begin{array}{c}\text { Above } \\
\text { reduced } \\
\text { a lot }\end{array}$ & $\begin{array}{l}\text { Above } \\
\text { reduced } \\
\text { a little }\end{array}$ & $\begin{array}{l}\text { Above } \\
\text { remain } \\
\text { the same }\end{array}$ & $\begin{array}{c}\text { Above } \\
\text { increased } \\
\text { a little }\end{array}$ & $\begin{array}{l}\text { Above } \\
\text { reduced } \\
\text { a lot }\end{array}$ & $\begin{array}{l}\text { Above } \\
\text { reduced } \\
\text { a little }\end{array}$ & $\begin{array}{l}\text { Above } \\
\text { remain } \\
\text { the same }\end{array}$ & $\begin{array}{c}\text { Above } \\
\text { increased } \\
\text { a little }\end{array}$ \\
\hline $\begin{array}{l}\text { Area of residence at age } 16 \\
\text { Foreign }\end{array}$ & $\begin{array}{r}3.790 * * * \\
(0.705)\end{array}$ & $\begin{array}{r}2.938 * * * \\
(0.367)\end{array}$ & $\begin{array}{r}2.091^{* * * *} \\
(0.275)\end{array}$ & $\begin{array}{r}1.603 * * \\
(0.297)\end{array}$ & $\begin{array}{r}.533 * * * \\
(0.705)\end{array}$ & $\begin{array}{r}2.789 * * * \\
(0.388)\end{array}$ & $\begin{array}{r}1.863^{* * * *} \\
(0.280)\end{array}$ & $\begin{array}{r} \\
1.676^{* *} \\
(0.362)\end{array}$ & $\begin{array}{r}3.519 * * * \\
(0.703)\end{array}$ & $\begin{array}{r}2.777^{* * * *} \\
(0.384)\end{array}$ & $\begin{array}{r}1.866^{* * * *} \\
(0.281)\end{array}$ & $\begin{array}{r}1.678^{* *} \\
(0.364)\end{array}$ \\
\hline Country, non-farm & $\begin{array}{r}0.928 \\
(0.0808)\end{array}$ & & & & $\begin{array}{r}0.943 \\
(0.0913)\end{array}$ & & & & $\begin{array}{r}0.955 \\
(0.0936)\end{array}$ & & & \\
\hline \multirow[t]{2}{*}{ Farm } & 0.882 & & & & 0.908 & & & & 0.924 & & & \\
\hline & $(0.0838)$ & & & & $(0.0946)$ & & & & $(0.0968)$ & & & \\
\hline Town: $<50,000$ & ref. & ref. & ref. & ref. & ref. & ref. & ref. & ref. & ref. & ref. & ref. & ref. \\
\hline City: 50,000 to 250,000 & $\begin{array}{r}1.140^{*} \\
(0.0882)\end{array}$ & & & & $\begin{array}{r}1.133 \\
(0.0958)\end{array}$ & & & & $\begin{array}{r}1.146 \\
(0.0968)\end{array}$ & & & \\
\hline \multirow[t]{2}{*}{ Big-city suburb } & $1.164 *$ & & & & $1.230^{* * *}$ & & & & $1.245 * *$ & & & \\
\hline & $(0.0921)$ & & & & $(0.110)$ & & & & $(0.112)$ & & & \\
\hline City: > 250,000 & $\begin{array}{r}1.019 \\
(0.0863) \\
\end{array}$ & & & & $\begin{array}{r}1.020 \\
(0.0923) \\
\end{array}$ & & & & $\begin{array}{r}1.019 \\
(0.0922) \\
\end{array}$ & & & \\
\hline \multirow{2}{*}{$\begin{array}{l}\text { Political party affiliation } \\
\text { Strong democrat }\end{array}$} & & & & & & & & & & & & \\
\hline & $\begin{array}{r}1.307 * * * \\
(0.109)\end{array}$ & & & & & & & & $\begin{array}{r}1.155 \\
(0.105)\end{array}$ & & & \\
\hline Democrat & ref. & ref. & ref. & ref. & & & & & ref. & & & \\
\hline Ind., near Dem. & $\begin{array}{r}1.271 * * * * \\
(0.107)\end{array}$ & & & & & & & & $\begin{array}{l}1.179 * \\
(0.104)\end{array}$ & & & \\
\hline \multirow[t]{2}{*}{ Independent } & 1.030 & & & & & & & & 1.031 & & & \\
\hline & $(0.0827)$ & & & & & & & & $(0.0891)$ & & & \\
\hline Ind., near Rep. & $\begin{array}{l}0.792^{* *} \\
(0.0756)\end{array}$ & & & & & & & & $0.793 * *$ & & & \\
\hline \multirow{2}{*}{ Republican } & $0.770^{* * *}$ & & & & & & & & $0.816^{* *}$ & & & \\
\hline & $(0.0634)$ & & & & & & & & $(0.0805)$ & & & \\
\hline Strong Republican & $\begin{array}{r}0.690^{* * * *} \\
(0.0675)\end{array}$ & & & & & & & & $\begin{array}{c}0.739 * * \\
(0.0891)\end{array}$ & & & \\
\hline Other party & $\begin{array}{r}1.076 \\
(0.232)\end{array}$ & $\begin{array}{r}1.207 \\
(0.235)\end{array}$ & $\begin{array}{r}2.275^{* * * *} \\
(0.583)\end{array}$ & $\begin{array}{l}1.860^{*} \\
(0.678)\end{array}$ & & & & & $\begin{array}{r}(0.0891) \\
1.313 \\
(0.279)\end{array}$ & & & \\
\hline \multirow{2}{*}{$\begin{array}{l}\text { Political views } \\
\text { Extremely liberal }\end{array}$} & & & & & & & & & & & & \\
\hline & & & & & $\begin{array}{r}1.001 \\
(0.178)\end{array}$ & $\begin{array}{r}1.908 * * * \\
(0.317)\end{array}$ & $\begin{array}{r}2.688^{* * * *} \\
(0.426)\end{array}$ & $\begin{array}{r}3.584 * * * \\
(0774)\end{array}$ & $\begin{array}{r}0.947 \\
(0.170)\end{array}$ & $\begin{array}{r}1.792^{* * * *} \\
(0.293)\end{array}$ & $\begin{array}{r}2.480^{* * * *} \\
(0.394)\end{array}$ & $3.298 * * *$ \\
\hline \multirow[t]{2}{*}{ Liberal } & & & & & $1.825^{* * * *}$ & & & & $1.707 * * *$ & & & \\
\hline & & & & & $(0.167)$ & & & & $(0.161)$ & & & \\
\hline Slightly liberal & & & & & $\begin{array}{r}1.259^{* * *} \\
(0.115)\end{array}$ & & & & $\begin{array}{r}1.205^{* *} \\
(0.110)\end{array}$ & & & \\
\hline Moderate & & & & & ref. & ref. & ref. & ref. & ref. & ref. & ref. & ref. \\
\hline Slightly conservative & & & & & $\begin{array}{r}1.163 \\
(0.126)\end{array}$ & $\begin{array}{r}0.911 \\
(0.0826)\end{array}$ & $\begin{array}{r}0.954 \\
(0.133)\end{array}$ & $\begin{array}{r}0.693 \\
(0.161)\end{array}$ & $\begin{array}{r}1.255^{* *} \\
(0.140)\end{array}$ & $\begin{array}{r}0.987 \\
(0.0933)\end{array}$ & $\begin{array}{r}1.032 \\
(0.149)\end{array}$ & $\begin{array}{r}0.750 \\
(0.175)\end{array}$ \\
\hline Conservative & & & & & $\begin{array}{l}0.854^{* * *} \\
(0.0675)\end{array}$ & & & & $\begin{array}{r}0.977 \\
(0.0857)\end{array}$ & & & \\
\hline Extremely conservative & & & & & $0.567 * * *$ & 0.784 & 1.171 & 1.420 & $0.629 * * *$ & 0.870 & 1.288 & 1.555 \\
\hline & & & & & $(0.0992)$ & $(0.143)$ & $(0.372)$ & $(0.509)$ & $(0.113)$ & $(0.165)$ & $(0.415)$ & $(0.562)$ \\
\hline Racial resentment & & & & & & & & & & & & \\
\hline & 1.102 & $1.212 * * *$ & $1.760^{* * * *}$ & $1.710^{* * * *}$ & 1.116 & $1.195 * *$ & $1.637^{* * * *}$ & $1.604 * * *$ & 1.083 & $1.160^{*}$ & $1.594 * * * *$ & $1.564 * * * *$ \\
\hline & $(0.0917)$ & $(0.0846)$ & $(0.155)$ & $(0.227)$ & $(0.103)$ & $(0.0917)$ & $(0.156)$ & $(0.245)$ & $(0.100)$ & $(0.0895)$ & $(0.150)$ & $(0.239)$ \\
\hline Medium & ref. & ref. & ref. & ref. & ref. & ref. & ref. & ref. & ref. & ref. & ref. & ref. \\
\hline High & $\begin{array}{r}0.444 * * * \\
(0.0389)\end{array}$ & $\begin{array}{r}0.598 * * * \\
(0.0487)\end{array}$ & $\begin{array}{r}0.674 * * * * \\
(0.0931)\end{array}$ & $\begin{array}{c}0.677^{*} \\
(0.148)\end{array}$ & $\begin{array}{r}0.418^{* * * *} \\
(0.0403)\end{array}$ & $\begin{array}{r}0.591 * * * \\
(0.0533)\end{array}$ & $\begin{array}{c}0.693 * * \\
(0.0998)\end{array}$ & $\begin{array}{r}0.759 \\
(0.177)\end{array}$ & $\begin{array}{r}0.427 * * * \\
(0.0414)\end{array}$ & $\begin{array}{r}0.604 * * * \\
(0.0556)\end{array}$ & $\begin{array}{r}0.709^{* *} * \\
(0.103)\end{array}$ & $\begin{array}{r}0.775 \\
(0.182)\end{array}$ \\
\hline Constant & $2.276^{* * *}$ & $0.592 * * *$ & $0.0589^{* * *}$ & $0.0133 * * *$ & $1.990^{* * *}$ & $0.519^{* * *}$ & $0.0498 * * *$ & $0.00880^{* * *}$ & $2.106 * * *$ & $0.546 * * *$ & $0.0519 * * *$ & $0.00912^{* * * *}$ \\
\hline & $(0.295)$ & $(0.0754)$ & $(0.00846)$ & $(0.00266)$ & $(0.274)$ & $(0.0711)$ & $(0.00780)$ & $(0.00182)$ & $(0.312)$ & $(0.0809)$ & $(0.00857)$ & $(0.00196)$ \\
\hline Observations & 8,189 & 8,189 & 8,189 & 8,189 & 7,037 & 7,037 & 7,037 & 7,037 & 7,037 & 7,037 & 7,037 & 7,037 \\
\hline
\end{tabular}

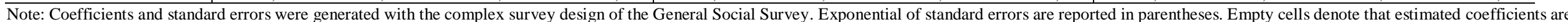

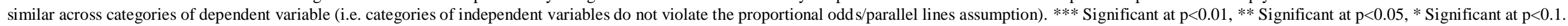

Source: 2004, 2008, 2010, 2012, 2014, and 2016 General Social Surveys. 
Table A3. Estimates from ordinary least squares models predicting opinion about how should the number of immigrants to America be nowadays, United States, 2004-2016 (complete version of Table 7)

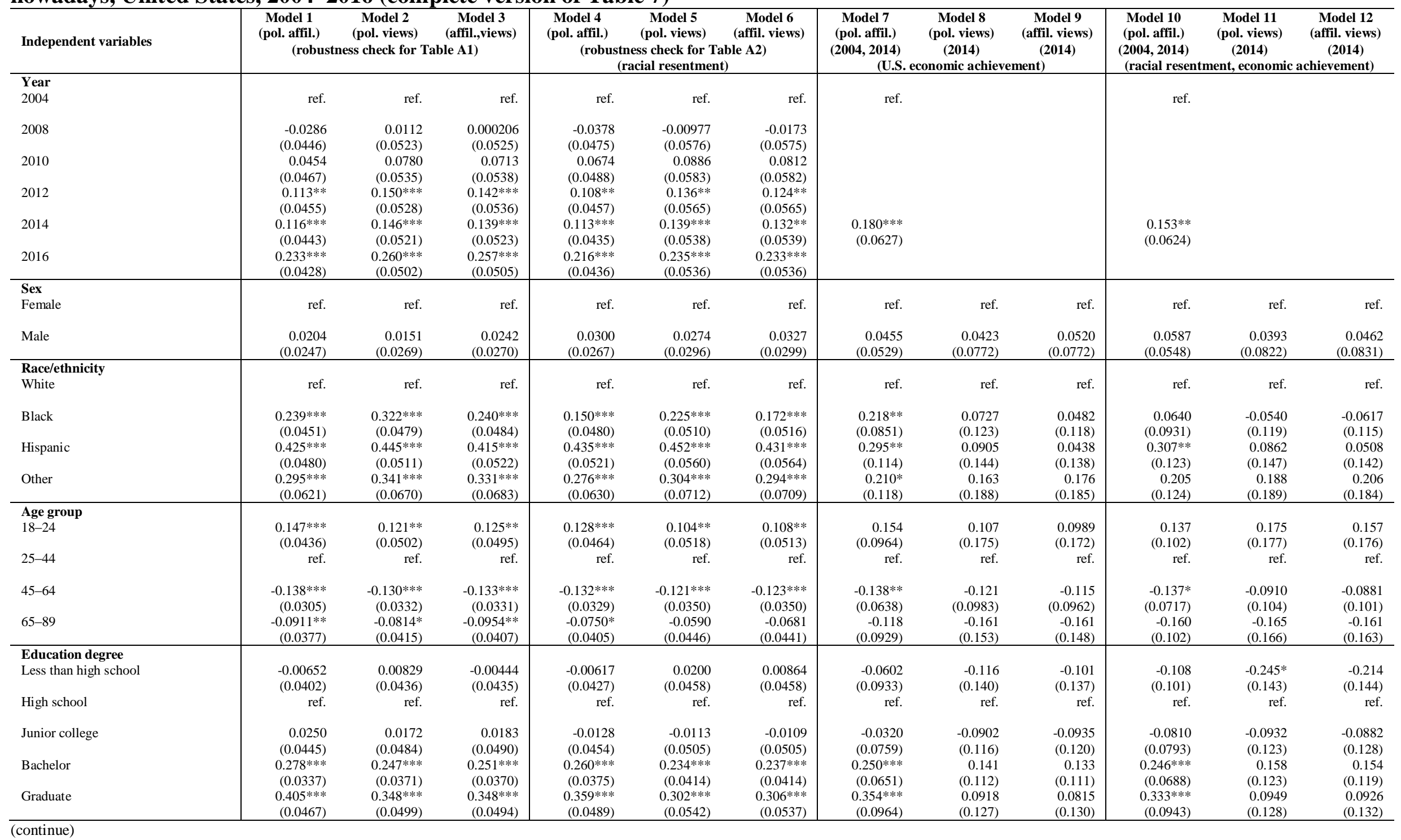




\begin{tabular}{|c|c|c|c|c|c|c|c|c|c|c|c|c|}
\hline Independent variables & $\begin{array}{l}\text { Model 1 } \\
\text { (pol. affil.) } \\
\text { (robust }\end{array}$ & \multicolumn{2}{|c|}{ (robustness check for Table A1) } & \multicolumn{3}{|c|}{$\begin{array}{c}\text { (robustness check for Table A2) } \\
\text { (racial resentment) }\end{array}$} & $\begin{array}{r}\text { Model } 7 \\
\text { (pol. affil.) } \\
(2004, \text { 2014) } \\
\text { (U.S. }\end{array}$ & $\begin{array}{c}\text { Model } 8 \\
\text { (pol. views) } \\
\text { (2014) } \\
\text { conomic achieve }\end{array}$ & 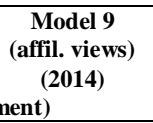 & $\begin{array}{c}\text { Model 10 } \\
\text { (pol. affil.) } \\
(2004,2014) \\
\text { (racial resent }\end{array}$ & 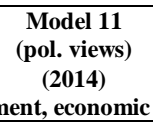 & $\begin{array}{c}\text { Model 12 } \\
\text { (affil. views) } \\
\text { (2014) } \\
\text { chievement) }\end{array}$ \\
\hline $\begin{array}{l}\text { Religion } \\
\text { Protestant }\end{array}$ & ref. & ref. & ref. & ref. & ref. & ref. & ref. & ref. & ref. & ref. & ref. & ref. \\
\hline Catholic & $\begin{array}{r}0.0716^{* *} \\
(0.0319)\end{array}$ & $\begin{array}{r}0.0872 * * \\
(0.0345)\end{array}$ & $\begin{array}{r}0.0795 * * \\
(0.0339)\end{array}$ & $\begin{array}{r}0.0705^{* *} \\
(0.0345)\end{array}$ & $\begin{array}{r}0.0854 * * \\
(0.0371)\end{array}$ & $\begin{array}{r}0.0830 * * \\
(0.0367)\end{array}$ & $\begin{array}{r}0.00968 \\
(0.0718)\end{array}$ & $\begin{array}{l}0.0247 \\
(0.110)\end{array}$ & $\begin{array}{l}0.0150 \\
(0.112)\end{array}$ & $\begin{array}{r}-0.0234 \\
(0.0754)\end{array}$ & $\begin{array}{r}0.00756 \\
(0.110)\end{array}$ & $\begin{array}{r}0.00602 \\
(0.113)\end{array}$ \\
\hline Christian & $\begin{array}{r}0.0617 \\
(0.0618)\end{array}$ & $\begin{array}{r}0.103 \\
(0.0670)\end{array}$ & $\begin{array}{r}0.0991 \\
(0.0681)\end{array}$ & $\begin{array}{r}0.0438 \\
(0.0638)\end{array}$ & $\begin{array}{r}0.0794 \\
(0.0690)\end{array}$ & $\begin{array}{r}0.0734 \\
(0.0695)\end{array}$ & $\begin{array}{r}0.00915 \\
(0.161)\end{array}$ & $\begin{array}{r}0.0276 \\
(0.178)\end{array}$ & $\begin{array}{r}0.0401 \\
(0.183)\end{array}$ & $\begin{array}{r}-0.0131 \\
(0.154)\end{array}$ & $\begin{array}{r}-0.0203 \\
(0.178)\end{array}$ & $\begin{array}{r}-0.0140 \\
(0.186)\end{array}$ \\
\hline Jewish & $\begin{array}{r}0.370^{* * * *} \\
(0.112)\end{array}$ & $\begin{array}{r}0.456^{* * *} \\
(0.121)\end{array}$ & $\begin{array}{r}0.418^{* * *} \\
(0.118)\end{array}$ & $\begin{array}{r}0.354 * * * \\
(0.120)\end{array}$ & $\begin{array}{r}0.435^{* * * *} \\
(0.129)\end{array}$ & $\begin{array}{r}0.408 * * * \\
(0.127)\end{array}$ & $\begin{array}{r}0.0621 \\
(0.236)\end{array}$ & $\begin{array}{r}0.596 * * * \\
(0.199)\end{array}$ & $\begin{array}{r}0.565^{* * *} \\
(0.204)\end{array}$ & $\begin{array}{r}0.0907 \\
(0.250)\end{array}$ & $\begin{array}{r}0.756^{* * * *} \\
(0.202)\end{array}$ & $\begin{array}{r}0.721 * * * \\
(0.216)\end{array}$ \\
\hline Other & $\begin{array}{r}0.243^{* * * *} \\
(0.0702)\end{array}$ & $\begin{array}{r}0.219^{* * *} \\
(0.0774)\end{array}$ & $\begin{array}{l}0.188 * * \\
(0.0774)\end{array}$ & $\begin{array}{r}0.245^{* * *} \\
(0.0758)\end{array}$ & $\begin{array}{r}0.250^{* * *} \\
(0.0864)\end{array}$ & $\begin{array}{r}0.226^{* * *} \\
(0.0862)\end{array}$ & $\begin{array}{r}0.301 * * \\
(0.136)\end{array}$ & $\begin{array}{r}-0.154 \\
(0.190)\end{array}$ & $\begin{array}{r}-0.159 \\
(0.190)\end{array}$ & $\begin{array}{r}0.188 \\
(0.133)\end{array}$ & $\begin{array}{r}-0.139 \\
(0.193)\end{array}$ & $\begin{array}{r}-0.141 \\
(0.191)\end{array}$ \\
\hline None & $\begin{array}{r}0.104 * * * \\
(0.0351) \\
\end{array}$ & $\begin{array}{r}0.124 * * * \\
(0.0391) \\
\end{array}$ & $\begin{array}{r}0.0946 * * \\
(0.0387) \\
\end{array}$ & $\begin{array}{r}0.0932^{* * *} \\
(0.0378) \\
\end{array}$ & $\begin{array}{r}0.113^{* * * *} \\
(0.0421) \\
\end{array}$ & $\begin{array}{r}0.0890^{* * *} \\
(0.0415) \\
\end{array}$ & $\begin{array}{r}-0.0673 \\
(0.0735)\end{array}$ & $\begin{array}{r}0.00535 \\
(0.110) \\
\end{array}$ & $\begin{array}{r}0.00245 \\
(0.109) \\
\end{array}$ & $\begin{array}{r}-0.101 \\
(0.0804) \\
\end{array}$ & $\begin{array}{r}-0.0378 \\
(0.113) \\
\end{array}$ & $\begin{array}{r}-0.0309 \\
(0.112) \\
\end{array}$ \\
\hline $\begin{array}{l}\text { Occupation } \\
\text { Management, business, } \\
\text { science, arts }\end{array}$ & ref. & ref. & ref. & ref. & ref. & ref. & ref. & ref. & ref. & ref. & ref. & ref. \\
\hline Service & $\begin{array}{r}-0.0637 \\
(0.0421)\end{array}$ & $\begin{array}{r}-0.0703 \\
(0.0449)\end{array}$ & $\begin{array}{r}-0.0730 \\
(0.0448)\end{array}$ & $\begin{array}{l}-0.0773 * \\
(0.0439)\end{array}$ & $\begin{array}{l}-0.108 * * \\
(0.0477)\end{array}$ & $\begin{array}{l}-0.108^{* *} \\
(0.0480)\end{array}$ & $\begin{array}{r}0.0541 \\
(0.0966)\end{array}$ & $\begin{array}{l}0.0247 \\
(0.116)\end{array}$ & $\begin{array}{l}0.0191 \\
(0.115)\end{array}$ & $\begin{array}{r}0.144 \\
(0.0941)\end{array}$ & $\begin{array}{l}0.0386 \\
(0.126)\end{array}$ & $\begin{array}{l}0.0391 \\
(0.125)\end{array}$ \\
\hline Sales, office & $\begin{array}{r}-0.134 * * * \\
(0.0347)\end{array}$ & $\begin{array}{r}-0.127 * * * * \\
(0.0379)\end{array}$ & $\begin{array}{r}-0.131 * * * * \\
(0.0379)\end{array}$ & $\begin{array}{r}-0.145^{* * * *} \\
(0.0373)\end{array}$ & $\begin{array}{r}-0.153 * * * \\
(0.0413)\end{array}$ & $\begin{array}{r}-0.153^{* * * *} \\
(0.0413)\end{array}$ & $\begin{array}{r}-0.0364 \\
(0.0751)\end{array}$ & $\begin{array}{r}-0.0338 \\
(0.115)\end{array}$ & $\begin{array}{r}-0.0559 \\
(0.123)\end{array}$ & $\begin{array}{r}-0.0233 \\
(0.0780)\end{array}$ & $\begin{array}{r}-0.0482 \\
(0.122)\end{array}$ & $\begin{array}{r}-0.0609 \\
(0.129)\end{array}$ \\
\hline $\begin{array}{l}\text { Natural resources, } \\
\text { construction, maintenance }\end{array}$ & $\begin{array}{r}-0.195^{* * *} \\
(0.0522)\end{array}$ & $\begin{aligned}-0.213^{* * * *} \\
(0.0575)\end{aligned}$ & $\begin{array}{r}-0.217 * * * * \\
(0.0581)\end{array}$ & $\begin{array}{r}-0.194 * * * * \\
(0.0546)\end{array}$ & $\begin{array}{r}-0.220 * * * * \\
(0.0598)\end{array}$ & $\begin{array}{r}-0.222^{* * * *} \\
(0.0603)\end{array}$ & $\begin{array}{l}-0.0117 \\
(0.116)\end{array}$ & $\begin{array}{r}-0.00251 \\
(0.141)\end{array}$ & $\begin{array}{r}0.00576 \\
(0.136)\end{array}$ & $\begin{array}{l}-0.0127 \\
(0.122)\end{array}$ & $\begin{array}{r}0.00303 \\
(0.155)\end{array}$ & 0.0118 \\
\hline $\begin{array}{l}\text { Production, transportation, } \\
\text { material moving }\end{array}$ & $\begin{array}{l}-0.0774^{*} \\
(0.0461)\end{array}$ & $\begin{array}{r}-0.0576 \\
(0.0517)\end{array}$ & $\begin{array}{r}-0.0637 \\
(0.0509)\end{array}$ & $\begin{array}{r}-0.0723 \\
(0.0487)\end{array}$ & $\begin{array}{r}-0.0600 \\
(0.0549)\end{array}$ & $\begin{array}{r}-0.0650 \\
(0.0545)\end{array}$ & $\begin{array}{r}-0.156^{*} \\
(0.0921)\end{array}$ & $\begin{array}{r}-0.232 \\
(0.154)\end{array}$ & $\begin{array}{r}-0.246 \\
(0.159)\end{array}$ & $\begin{array}{r}-0.107 \\
(0.102)\end{array}$ & $\begin{array}{r}-0.125 \\
(0.170)\end{array}$ & $\begin{array}{r}-0.133 \\
(0.178)\end{array}$ \\
\hline Military & $\begin{array}{l}-0.227^{*} \\
(0.117)\end{array}$ & $\begin{array}{l}-0.240^{*} \\
(0.125)\end{array}$ & $\begin{array}{l}-0.229^{*} \\
(0.122)\end{array}$ & $\begin{array}{l}-0.227^{*} \\
(0.133)\end{array}$ & $\begin{array}{l}-0.238^{*} \\
(0.142)\end{array}$ & $\begin{array}{l}-0.234^{*} \\
(0.140)\end{array}$ & $\begin{array}{l}-0.289^{*} \\
(0.173)\end{array}$ & $\begin{array}{c}-0.347 * \\
(0.181)\end{array}$ & $\begin{array}{l}-0.347^{*} \\
(0.181)\end{array}$ & $\begin{array}{r}-0.315 \\
(0.195)\end{array}$ & $\begin{array}{r}-0.419^{* *} \\
(0.179)\end{array}$ & $\begin{array}{r}-0.418^{* *} \\
(0.178)\end{array}$ \\
\hline Unspecified & $\begin{array}{l}-0.0478 \\
(0.144)\end{array}$ & $\begin{array}{l}-0.0687 \\
(0.173)\end{array}$ & $\begin{array}{l}-0.0874 \\
(0.170)\end{array}$ & $\begin{array}{r}-0.177 \\
(0.167)\end{array}$ & $\begin{array}{l}-0.247 \\
(0.209)\end{array}$ & $\begin{array}{r}-0.253 \\
(0.211)\end{array}$ & $\begin{array}{r}0.201 \\
(0.275)\end{array}$ & $\begin{array}{r}0.221 \\
(0.613)\end{array}$ & $\begin{array}{r}0.117 \\
(0.576)\end{array}$ & $\begin{array}{r}0.121 \\
(0.277)\end{array}$ & $\begin{array}{r}0.174 \\
(0.592)\end{array}$ & $\begin{array}{r}0.104 \\
(0.560)\end{array}$ \\
\hline Unemployed & $\begin{array}{r}-0.0730 \\
(0.0728)\end{array}$ & $\begin{array}{r}-0.0450 \\
(0.0756)\end{array}$ & $\begin{array}{r}-0.0427 \\
(0.0753)\end{array}$ & $\begin{array}{r}-0.125 \\
(0.0776)\end{array}$ & $\begin{array}{r}-0.0867 \\
(0.0789)\end{array}$ & $\begin{array}{r}-0.0849 \\
(0.0787)\end{array}$ & $\begin{array}{l}0.0931 \\
(0.175)\end{array}$ & $\begin{array}{r}0.409 \\
(0.268)\end{array}$ & $\begin{array}{r}0.379 \\
(0.262)\end{array}$ & $\begin{array}{l}0.0664 \\
(0.196)\end{array}$ & $\begin{array}{r}0.421 \\
(0.280)\end{array}$ & $\begin{array}{r}0.406 \\
(0.278)\end{array}$ \\
\hline Region of interview & & & & & & & & & & & & \\
\hline New England & $\begin{array}{r}0.170^{* * * *} \\
(0.0610)\end{array}$ & $\begin{array}{r}0.113 * \\
(0.0662)\end{array}$ & $\begin{array}{r}0.0993 \\
(0.0656)\end{array}$ & $\begin{array}{c}0.145 * * \\
(0.0660)\end{array}$ & $\begin{array}{r}0.108 \\
(0.0682)\end{array}$ & $\begin{array}{r}0.0972 \\
(0.0681)\end{array}$ & $\begin{array}{r}0.371 * * \\
(0.164)\end{array}$ & $\begin{array}{l}0.262^{*} \\
(0.151)\end{array}$ & $\begin{array}{c}0.242 * \\
(0.136)\end{array}$ & $\begin{array}{r}0.358^{* * *} \\
(0.179)\end{array}$ & $\begin{array}{r}0.297 * * \\
(0.123)\end{array}$ & $\begin{array}{r}0.278^{* * *} \\
(0.122)\end{array}$ \\
\hline Middle Atlantic & $\begin{array}{r}0.0748 \\
(0.0519)\end{array}$ & $\begin{array}{r}0.0518 \\
(0.0535)\end{array}$ & $\begin{array}{r}0.0469 \\
(0.0537)\end{array}$ & $\begin{array}{r}0.0626 \\
(0.0535)\end{array}$ & $\begin{array}{r}0.0417 \\
(0.0553)\end{array}$ & $\begin{array}{r}0.0387 \\
(0.0554)\end{array}$ & $\begin{array}{l}0.190^{*} \\
(0.106)\end{array}$ & $\begin{array}{l}0.243^{*} \\
(0.135)\end{array}$ & $\begin{array}{l}0.227^{*} \\
(0.132)\end{array}$ & $\begin{array}{r}0.161 \\
(0.107)\end{array}$ & $\begin{array}{l}0.246^{*} \\
(0.127)\end{array}$ & $\begin{array}{l}0.235^{*} \\
(0.126)\end{array}$ \\
\hline East North Central & $0.0898^{* *}$ & $\begin{array}{r}0.0995^{* *} \\
(0.0456)\end{array}$ & $\begin{array}{r}0.0913 * * \\
(0.0454)\end{array}$ & $0.0938^{* * *}$ & $0.104 * *$ & $0.0965^{* *}$ & $\begin{array}{r}0.117 \\
0.117\end{array}$ & 0.186 & 0.164 & 0.123 & 0.199 & 0.180 \\
\hline West North Central & $\begin{array}{l}(0.0404) \\
0.114 * * \\
(0.0533)\end{array}$ & $\begin{array}{c}(0.0450) \\
0.124 * * \\
(0.0609)\end{array}$ & $\begin{array}{r}(0.0454) \\
0.110^{*} \\
(0.0606)\end{array}$ & $\begin{array}{l}(0.0402) \\
0.135 * * \\
(0.0555)\end{array}$ & $\begin{array}{c}(0.0453) \\
0.144^{* *} \\
(0.0670)\end{array}$ & $\begin{array}{r}0.0452) \\
0.133 * * \\
(0.0664)\end{array}$ & $\begin{array}{r}0.08 / 8) \\
0.0623 \\
(0.0868)\end{array}$ & $\begin{array}{l}(0.13) \\
0.0287 \\
(0.144)\end{array}$ & $\begin{array}{l}(0.134) \\
0.0457 \\
0.148)\end{array}$ & $\begin{array}{r}(0.0800) \\
0.0304 \\
(0.0785)\end{array}$ & $\begin{array}{l}-0.134) \\
-0.0609 \\
(0.124)\end{array}$ & -0.0550 \\
\hline South Atlantic & ref. & ref. & & ref. & & ref. & ref. & ref. & ref. & & ref. & ref. \\
\hline East South Central & $\begin{array}{r}0.0629 \\
(0.0668)\end{array}$ & $\begin{array}{r}0.0534 \\
(0.0725)\end{array}$ & $\begin{array}{r}0.0560 \\
(0.0729)\end{array}$ & $\begin{array}{r}0.0782 \\
(0.0730)\end{array}$ & $\begin{array}{r}0.0575 \\
(0.0818)\end{array}$ & $\begin{array}{r}0.0600 \\
(0.0823)\end{array}$ & $\begin{array}{r}0.0810 \\
(0.138)\end{array}$ & $\begin{array}{l}0.0347 \\
(0.149)\end{array}$ & $\begin{array}{l}0.0178 \\
(0.149)\end{array}$ & $\begin{array}{r}0.125 \\
(0.136)\end{array}$ & $\begin{array}{r}0.123 \\
(0.166)\end{array}$ & $\begin{array}{l}0.0994 \\
(0.166)\end{array}$ \\
\hline West South Central & $\begin{array}{r}0.0614 \\
(0.0509)\end{array}$ & $\begin{array}{r}0.0812 \\
(0.0553)\end{array}$ & $\begin{array}{r}0.0791 \\
(0.0555)\end{array}$ & $\begin{array}{r}0.0780 \\
(0.0511)\end{array}$ & $\begin{array}{l}0.0992^{*} \\
(0.0568)\end{array}$ & $\begin{array}{c}0.0971^{*} \\
(0.0567)\end{array}$ & $\begin{array}{r}-0.0453 \\
(0.129)\end{array}$ & $\begin{array}{r}-0.0222 \\
(0.188)\end{array}$ & $\begin{array}{c}-0.0281 \\
(0.189)\end{array}$ & $\begin{array}{c}-0.0183 \\
(0.125)\end{array}$ & $\begin{array}{r}-0.0315 \\
(0.160)\end{array}$ & $\begin{array}{l}-0.0435 \\
(0.165)\end{array}$ \\
\hline Mountain & $\begin{array}{r}0.178^{* * *} \\
(0.0543)\end{array}$ & $\begin{array}{r}0.167 * * * \\
(0.0597)\end{array}$ & $\begin{array}{r}0.165 * * * \\
(0.0596)\end{array}$ & $\begin{array}{r}0.156^{* * *} \\
(0.0559)\end{array}$ & $\begin{array}{c}0.149 * * \\
(0.0621)\end{array}$ & $0.146 * *$ & 0.128 & 0.0983 & 0.0689 & 0.0381 & 0.0383 & 0.0195 \\
\hline Pacific & $\begin{array}{r}(0.0545) \\
0.0899 * * \\
(0.0450)\end{array}$ & $\begin{array}{r}(0.059 /) \\
0.0785 \\
(0.0480)\end{array}$ & $\begin{array}{r}(0.00596) \\
0.0726 \\
(0.0474)\end{array}$ & $\begin{array}{r}(0.00539) \\
0.0747 \\
(0.0471)\end{array}$ & $\begin{array}{r}(0.0621) \\
0.0663 \\
(0.0505)\end{array}$ & $\begin{array}{r}(0.0622) \\
0.0613 \\
(0.0500)\end{array}$ & 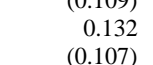 & $\begin{array}{c}\left(0.1418^{* *}\right. \\
(0.132)\end{array}$ & $\begin{array}{r}(0.142)^{* *} \\
(0.131)\end{array}$ & $\begin{array}{r}0.126 \\
(0.117)\end{array}$ & $\begin{array}{l}0.286^{*} \\
(0.147)\end{array}$ & $\begin{array}{l}0.290^{*} \\
(0.148)\end{array}$ \\
\hline
\end{tabular}




\begin{tabular}{|c|c|c|c|c|c|c|c|c|c|c|c|c|}
\hline Independent variables & \multicolumn{3}{|c|}{ (robustness check for Table A1) } & $\begin{array}{c}\begin{array}{c}\text { Model } 4 \\
\text { (pol. affil.) } \\
\text { (robust }\end{array} \\
\end{array}$ & $\begin{array}{l}\text { Model } 5 \\
\text { (pol. views) } \\
\text { ss check for Ta } \\
\text { cial resentmen }\end{array}$ & $\begin{array}{l}\text { Model 6 } \\
\text { (affil. views) } \\
\text { le A2) }\end{array}$ & $\begin{array}{r}\text { Model } 7 \\
\text { (pol. affil.) } \\
(2004, \text { 2014) } \\
\text { (U.S. }\end{array}$ & $\begin{array}{c}\text { Model } 8 \\
\text { (pol. views) } \\
\text { (2014) } \\
\text { onomic achiev }\end{array}$ & 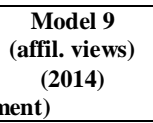 & $\begin{array}{c}\text { Model 10 } \\
\text { (pol. affil.) } \\
\text { (2004, 2014) } \\
\text { (racial resent }\end{array}$ & $\begin{array}{c}\text { Model 11 } \\
\text { (pol. views) } \\
\text { (2014) } \\
\text { ent, economic a }\end{array}$ & $\begin{array}{c}\text { Model 12 } \\
\text { (affil. views) } \\
(2014) \\
\text { chievement) } \\
\end{array}$ \\
\hline $\begin{array}{l}\text { Area of residence at age } 16 \\
\text { Foreign }\end{array}$ & $0.449^{* * *}$ & $0.422 * * *$ & $0.416^{* * * *}$ & $0.495 * * *$ & $0.463 * * *$ & $0.461 * * *$ & $0.473^{* * * *}$ & $0.452 * * *$ & $0.434 * * *$ & $0.483 * * *$ & $0.408^{* *}$ & $0.402^{* *}$ \\
\hline & $(0.0493)$ & $(0.0545)$ & $(0.0546)$ & $(0.0533)$ & $(0.0600)$ & $(0.0598)$ & $(0.122)$ & $(0.161)$ & $(0.150)$ & $(0.130)$ & $(0.177)$ & $(0.166)$ \\
\hline Country, non-farm & -0.0621 & -0.0551 & -0.0457 & -0.0343 & -0.0301 & -0.0222 & -0.138 & 0.0297 & 0.0440 & -0.109 & 0.0232 & 0.0432 \\
\hline Farm & $\begin{array}{r}(0.0423) \\
-0.0960^{*}\end{array}$ & $\begin{array}{r}(0.0483) \\
-0.0699\end{array}$ & $\begin{array}{r}(0.0485) \\
-0.0581\end{array}$ & $\begin{array}{r}(0.0460) \\
-0.0675\end{array}$ & $\begin{array}{r}(0.0520) \\
-0.0455\end{array}$ & $\begin{array}{r}(0.0523) \\
-0.0374\end{array}$ & $\begin{array}{r}(0.0892) \\
-0.265 * *\end{array}$ & $\begin{array}{l}(0.157) \\
-0.114\end{array}$ & $\begin{array}{r}(0.157) \\
-0.0747\end{array}$ & $(0.0909)$ & $(0.169)$ & $(0.171)$ \\
\hline гаштा & $(0.0507)$ & $(0.0558)$ & $\begin{array}{l}-0.0501 \\
(0.0556)\end{array}$ & $(0.0515)$ & $(0.0569)$ & $\begin{array}{l}-0.05 / 4 \\
(0.0569)\end{array}$ & $\begin{array}{r}-0.205 \\
(0.109)\end{array}$ & $\begin{array}{l}-0.114 \\
(0.230)\end{array}$ & $\begin{array}{l}-0.0 / 41 \\
(0.237)\end{array}$ & $\begin{array}{l}-0.200 \\
(0.118)\end{array}$ & $(0.235)$ & $(0.239)$ \\
\hline Town: $<50,000$ & ref. & & ref. & ref. & ref. & ref. & ref. & ref. & ref. & ref. & & \\
\hline City: 50,000 to 250,000 & $\begin{array}{r}0.0590 \\
(0.0395)\end{array}$ & $\begin{array}{r}0.0554 \\
(0.0427)\end{array}$ & $\begin{array}{r}0.0636 \\
(0.0426)\end{array}$ & $\begin{array}{r}0.0660 \\
(0.0420)\end{array}$ & $\begin{array}{r}0.0638 \\
(0.0459)\end{array}$ & $\begin{array}{r}0.0699 \\
(0.0455)\end{array}$ & $\begin{array}{r}-0.0242 \\
(0.0893)\end{array}$ & $\begin{array}{l}0.0612 \\
(0.149)\end{array}$ & $\begin{array}{l}0.0795 \\
(0.146)\end{array}$ & $\begin{array}{r}-0.0262 \\
(0.0956)\end{array}$ & $\begin{array}{c}-0.0158 \\
(0.156)\end{array}$ & $\begin{array}{r}0.00980 \\
(0.153)\end{array}$ \\
\hline Big-city suburb & $\begin{array}{c}0.0749^{*} \\
(0.0396)\end{array}$ & $\begin{array}{r}0.0949 * * \\
(0.0442)\end{array}$ & $\begin{array}{l}0.104 * * \\
(0.0441)\end{array}$ & $\begin{array}{c}0.0793^{*} \\
(0.0429)\end{array}$ & $\begin{array}{l}0.114 * * \\
(0.0484)\end{array}$ & $\begin{array}{l}0.120^{* * *} \\
(0.0482)\end{array}$ & $\begin{array}{r}-0.107 \\
(0.0808)\end{array}$ & $\begin{array}{l}0.0402 \\
(0.124)\end{array}$ & $\begin{array}{l}0.0532 \\
(0.120)\end{array}$ & $\begin{array}{r}-0.118 \\
(0.0842)\end{array}$ & $\begin{array}{c}0.0144 \\
(0.128)\end{array}$ & $\begin{array}{l}0.0272 \\
(0.123)\end{array}$ \\
\hline City: $>250,000$ & $\begin{array}{r}0.0226 \\
(0.0440)\end{array}$ & $\begin{array}{r}0.0225 \\
(0.0465)\end{array}$ & $\begin{array}{r}0.0210 \\
(0.0462)\end{array}$ & $\begin{array}{r}0.0218 \\
(0.0458)\end{array}$ & $\begin{array}{r}0.0192 \\
(0.0490)\end{array}$ & $\begin{array}{r}0.0180 \\
(0.0487)\end{array}$ & $\begin{array}{r}0.0113 \\
(0.0889)\end{array}$ & $\begin{array}{r}0.203 \\
(0.126)\end{array}$ & $\begin{array}{r}0.214 \\
(0.133)\end{array}$ & $\begin{array}{r}0.0478 \\
(0.0915)\end{array}$ & $\begin{array}{r}0.170 \\
(0.118)\end{array}$ & $\begin{array}{r}0.184 \\
(0.125) \\
\end{array}$ \\
\hline \multicolumn{13}{|l|}{ Political party affiliation } \\
\hline $\begin{array}{l}\text { Strong democrat } \\
\text { Democrat }\end{array}$ & $\begin{array}{r}0.179^{* * *} \\
(0.0435) \\
\text { ref. }\end{array}$ & & $\begin{array}{r}0.0991 * * \\
(0.0492) \\
\text { ref. }\end{array}$ & $\begin{array}{r}0.154 * * * \\
(0.0452) \\
\text { ref. }\end{array}$ & & $\begin{array}{r}0.0870^{*} \\
(0.0503) \\
\text { ref. }\end{array}$ & $\begin{array}{r}0.153^{*} \\
(0.0877) \\
\text { ref. }\end{array}$ & & $\begin{array}{r}-0.256 \\
(0.160) \\
\text { ref }\end{array}$ & $\begin{array}{r}0.103 \\
(0.0921)\end{array}$ & & $\begin{array}{r}-0.200 \\
(0.154)\end{array}$ \\
\hline \multirow[t]{2}{*}{ Ind., near Dem. } & $0.118^{* * * *}$ & & $0.0768 *$ & $0.136^{* * * *}$ & & $0.0967^{* *}$ & $0.178^{*}$ & & $-0.228^{*}$ & $0.194 *$ & & -0.145 \\
\hline & $(0.0424)$ & & $(0.0456)$ & $(0.0461)$ & & $(0.0488)$ & $(0.0912)$ & & $(0.127)$ & (0.0987) & & $(0.132)$ \\
\hline Independent & $\begin{array}{l}-0.00528 \\
(0.0397)\end{array}$ & & $\begin{array}{l}0.00162 \\
(0.0439)\end{array}$ & $\begin{array}{r}0.0180 \\
0.0431)\end{array}$ & & $\begin{array}{r}0.0136 \\
0.0465)\end{array}$ & $\begin{array}{r}-0.0417 \\
(0.0870)\end{array}$ & & $\begin{array}{r}-0.249 * * \\
(0.118)\end{array}$ & $\begin{array}{r}-0.0236 \\
(0.0976)\end{array}$ & & $\begin{array}{r}-0.222 \\
(0.137)\end{array}$ \\
\hline \multirow{2}{*}{ Ind., near Rep. } & $-0.181^{* * * *}$ & & $-0.184 * * *$ & $-0.130 * * *$ & & $-0.126 * *$ & -0.0308 & & $-0.483 * * *$ & -0.0328 & & $-0.367 * *$ \\
\hline & $(0.0482)$ & & $(0.0540)$ & $(0.0499)$ & & $(0.0560)$ & $(0.112)$ & & $(0.160)$ & $(0.113)$ & & $(0.159)$ \\
\hline \multirow[t]{2}{*}{ Republican } & $-0.179^{* * *}$ & & $-0.142 * * *$ & $-0.135^{* * *}$ & & $-0.106^{* * *}$ & -0.120 & & -0.191 & -0.0924 & & -0.148 \\
\hline & $(0.0418)$ & & $(0.0505)$ & $(0.0442)$ & & $(0.0529)$ & $(0.0870)$ & & $(0.143)$ & (0.0930) & & $(0.169)$ \\
\hline \multirow[t]{2}{*}{ Strong Republican } & $-0.255^{* * * *}$ & & $-0.205 * * *$ & $-0.179 * * *$ & & $-0.148^{* *}$ & $-0.234 * *$ & & $-0.320^{*}$ & $-0.181^{*}$ & & -0.245 \\
\hline & $(0.0460)$ & & $(0.0577)$ & $(0.0494)$ & & $(0.0606)$ & $(0.0932)$ & & $(0.172)$ & $(0.100)$ & & $(0.185)$ \\
\hline \multirow[t]{2}{*}{ Other party } & $0.182 *$ & & 0.144 & $0.228 * *$ & & 0.180 & 0.000708 & & -0.330 & 0.0948 & & -0.150 \\
\hline & $(0.0991)$ & & $(0.104)$ & $(0.107)$ & & $(0.112)$ & $(0.325)$ & & $(0.441)$ & $(0.379)$ & & $(0.491)$ \\
\hline \multirow{2}{*}{$\begin{array}{l}\text { Political views } \\
\text { Extremely liberal }\end{array}$} & & & & & & & & & & & & \\
\hline & & $\begin{array}{r}0.472 * * * * \\
(0.0795)\end{array}$ & $0.413 * * *$ & & $\begin{array}{r}0.405^{* * *} \\
(0.0856)\end{array}$ & $0.362 * * *$ & & $0.668 * * *$ & $0.665 * * *$ & & $0.720 * * *$ & $0.712 * * *$ \\
\hline \multirow[t]{2}{*}{ Liberal } & & $0.356^{* * * *}$ & $0.302 * * *$ & & $0.331^{* * * *}$ & $0.291^{* * * *}$ & & $0.374 * * *$ & $0.388^{* *}$ & & $0.396 * * *$ & $0.402 * *$ \\
\hline & & $(0.0480)$ & $(0.0503)$ & & $(0.0496)$ & $(0.0518)$ & & $(0.135)$ & $(0.148)$ & & $(0.141)$ & $(0.154)$ \\
\hline \multirow[t]{2}{*}{ Slightly liberal } & & $0.172 * * *$ & $0.140 * * *$ & & $0.145^{* * *}$ & $0.121 * *$ & & 0.110 & 0.0808 & & 0.0746 & 0.0499 \\
\hline & & $(0.0447)$ & $(0.0449)$ & & $(0.0476)$ & $(0.0479)$ & & $(0.120)$ & $(0.125)$ & & $(0.128)$ & $(0.132)$ \\
\hline Moderate & & ref. & ref. & & ref. & ref. & & ref. & ref. & & ref. & ref. \\
\hline \multirow[t]{2}{*}{ Slightly conservative } & & $1.45 \mathrm{e}-05$ & 0.0485 & & 0.00729 & 0.0465 & & -0.0669 & -0.0218 & & -0.0350 & 0.000768 \\
\hline & & $(0.0389)$ & $(0.0409)$ & & $(0.0421)$ & (0.0444) & & $(0.123)$ & $(0.128)$ & & $(0.121)$ & $(0.125)$ \\
\hline \multirow[t]{2}{*}{ Conservative } & & $-0.117 * * *$ & -0.0300 & & $-0.0754^{*}$ & -0.00837 & & $-0.316^{* *}$ & $-0.270 * *$ & & $-0.271^{*}$ & $-0.235^{*}$ \\
\hline & & $(0.0381)$ & $(0.0429)$ & & $(0.0411)$ & $(0.0452)$ & & $(0.128)$ & $(0.129)$ & & $(0.139)$ & $(0.140)$ \\
\hline \multirow[t]{2}{*}{ Extremely conservative } & & $-0.188 * *$ & -0.115 & & -0.148 & -0.0964 & & $-0.534 * *$ & $-0.446^{*}$ & & $-0.631^{* * * *}$ & -0.561 ** \\
\hline & & $(0.0906)$ & $(0.0922)$ & & $(0.0960)$ & $(0.0980)$ & & $(0.234)$ & $(0.242)$ & & $(0.213)$ & $(0.215)$ \\
\hline
\end{tabular}




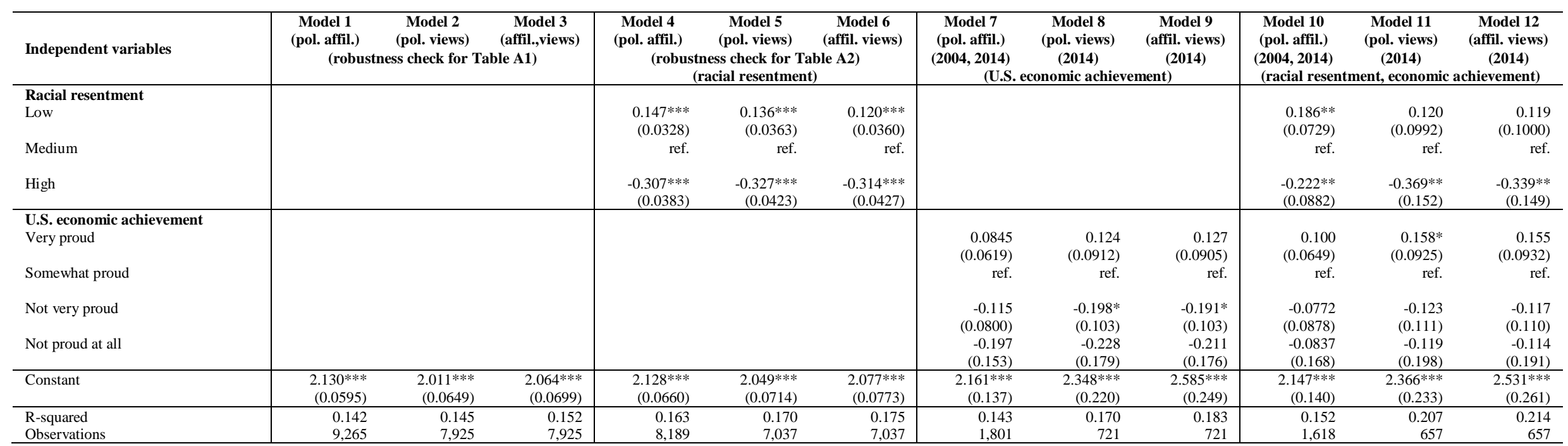

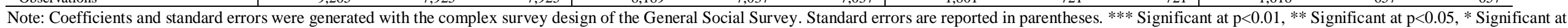
p<0.1.

Source: 2004, 2008, 2010, 2012, 2014, and 2016 General Social Surveys. 
Table A4. Odds ratios from generalized ordered logit models predicting opinion about how should the number of immigrants to America be nowadays, including county-level variables, United States, 2008-2014 (complete version of Table 8)

\begin{tabular}{|c|c|c|c|c|c|c|c|c|c|c|c|c|}
\hline \multirow[b]{2}{*}{ Independent variables } & \multicolumn{4}{|c|}{ Model 1 (political party affiliation) } & \multicolumn{4}{|c|}{ Model 2 (political views) } & \multicolumn{4}{|c|}{ Model 3 (political party affiliation $\&$ political views) } \\
\hline & $\begin{array}{c}\text { Above } \\
\text { reduced } \\
\text { a lot }\end{array}$ & $\begin{array}{l}\text { Above } \\
\text { reduced } \\
\text { a little }\end{array}$ & $\begin{array}{l}\text { Above } \\
\text { remain } \\
\text { the same }\end{array}$ & $\begin{array}{c}\text { Above } \\
\text { increased } \\
\text { a little } \\
\end{array}$ & $\begin{array}{c}\text { Above } \\
\text { reduced } \\
\text { a lot }\end{array}$ & $\begin{array}{l}\text { Above } \\
\text { reduced } \\
\text { a little }\end{array}$ & $\begin{array}{l}\text { Above } \\
\text { remain } \\
\text { the same }\end{array}$ & $\begin{array}{c}\text { Above } \\
\text { increased } \\
\text { a little }\end{array}$ & $\begin{array}{c}\text { Above } \\
\text { reduced } \\
\text { a lot }\end{array}$ & $\begin{array}{c}\text { Above } \\
\text { reduced } \\
\text { a little }\end{array}$ & $\begin{array}{l}\text { Above } \\
\text { remain } \\
\text { the same }\end{array}$ & $\begin{array}{c}\text { Above } \\
\text { increased } \\
\text { a little }\end{array}$ \\
\hline $\begin{array}{l}\text { Year } \\
2008\end{array}$ & ref. & & & & ref. & & & & ref. & & & \\
\hline $\begin{array}{l}2012 \\
2014\end{array}$ & $\begin{array}{r}1.133 \\
(0.106) \\
1.271^{* *} \\
(0.120) \\
1.278^{* * *} \\
(0.105) \\
\end{array}$ & & & & $\begin{array}{r}1.099 \\
(0.105) \\
1.236^{* *} \\
(0.119) \\
1.242^{* *} \\
(0.106)\end{array}$ & & & & $\begin{array}{r}1.116 \\
(0.108) \\
1.254^{* *} \\
(0.122) \\
1.260^{* * * *} \\
(0.110) \\
\end{array}$ & & & \\
\hline $\begin{array}{l}\text { Sex } \\
\text { Female }\end{array}$ & ref. & & & & ref. & & & & ref. & & & \\
\hline Male & $\begin{array}{r}1.002 \\
(0.0692)\end{array}$ & & & & $\begin{array}{r}1.001 \\
(0.0734)\end{array}$ & & & & $\begin{array}{r}1.019 \\
(0.0741)\end{array}$ & & & \\
\hline $\begin{array}{l}\text { Race/ethnicity } \\
\text { White }\end{array}$ & ref. & ref. & ref. & ref. & ref. & ref. & ref. & ref. & ref. & ref. & ref. & ref. \\
\hline $\begin{array}{l}\text { Black } \\
\text { Hispanic } \\
\text { Other }\end{array}$ & $\begin{array}{r}1.399 * * \\
(0.196) \\
2.233 * * * \\
(0.423) \\
1.723 * * * \\
(0.235)\end{array}$ & $\begin{array}{r}1.325^{* *} \\
(0.146) \\
2.317^{* * * *} \\
(0.348)\end{array}$ & $\begin{array}{r}1.726 * * * \\
(0.238) \\
1.469^{* * *} \\
(0.259)\end{array}$ & $\begin{array}{r}2.647 * * * \\
(0.542) \\
2.079 * * * \\
(0.413)\end{array}$ & $\begin{array}{r}1.673^{* * *} \\
(0.229) \\
2.194^{* * *} \\
(0.428) \\
1.849^{* * *} \\
(0.255)\end{array}$ & $\begin{array}{r}1.525 * * * \\
(0.161) \\
2.393 * * * \\
(0.364)\end{array}$ & $\begin{array}{r}1.862^{* * * *} \\
(0.258) \\
1.552 * * \\
(0.274)\end{array}$ & $\begin{array}{r}2.720^{* * * *} \\
(0.612) \\
2.101^{* * *} \\
(0.449)\end{array}$ & $\begin{array}{r}1.475^{* * *} \\
(0.214) \\
2.107 * * * \\
(0.413) \\
1.838^{* * *} \\
(0.257)\end{array}$ & $\begin{array}{c}1.358 * * * \\
(0.150) \\
2.303 * * * \\
(0.352)\end{array}$ & $\begin{array}{c}1.689 * * * \\
(0.238) \\
1.502 * * \\
(0.267)\end{array}$ & $\begin{array}{c}2.479 * * * \\
(0.553) \\
2.045^{* * *} \\
(0.441)\end{array}$ \\
\hline $\begin{array}{l}\text { Age group } \\
18-24 \\
25-44\end{array}$ & $\begin{array}{r}1.227 * \\
(0.147) \\
\text { ref. }\end{array}$ & ref. & ref. & ref. & $\begin{array}{r}1.143 \\
(0.143) \\
\text { ref. }\end{array}$ & ref. & ref. & ref. & $\begin{array}{r}1.157 \\
(0.142) \\
\text { ref. }\end{array}$ & ref. & ref. & ref. \\
\hline $\begin{array}{l}45-64 \\
65-89\end{array}$ & $\begin{array}{r}0.669 * * * \\
(0.0648) \\
0.677 * * * \\
(0.0775) \\
\end{array}$ & $\begin{array}{r}0.831^{* * *} \\
(0.0755) \\
0.830^{*} \\
(0.0805) \\
\end{array}$ & $\begin{array}{r}0.866 \\
(0.106) \\
0.984 \\
(0.148) \\
\end{array}$ & $\begin{array}{r}1.084 \\
(0.202) \\
0.725 \\
(0.197) \\
\end{array}$ & $\begin{array}{r}0.681^{* * *} \\
(0.0690) \\
0.678^{* * *} \\
(0.0795) \\
\end{array}$ & $\begin{array}{r}0.847 * \\
(0.0772) \\
0.862 \\
(0.0850) \\
\end{array}$ & $\begin{array}{r}0.863 \\
(0.107) \\
1.021 \\
(0.160) \\
\end{array}$ & $\begin{array}{r}1.070 \\
(0.202) \\
0.689 \\
(0.200) \\
\end{array}$ & $\begin{array}{r}0.680^{* * * *} \\
(0.0695) \\
0.666 * * * \\
(0.0783) \\
\end{array}$ & $\begin{array}{c}0.847^{*} \\
(0.0784) \\
0.847^{*} \\
(0.0837) \\
\end{array}$ & $\begin{array}{c}0.864 \\
(0.108) \\
1.003 \\
(0.155) \\
\end{array}$ & $\begin{array}{c}1.072 \\
(0.203) \\
0.676 \\
(0.197) \\
\end{array}$ \\
\hline $\begin{array}{l}\text { Education degree } \\
\text { Less than high school } \\
\text { High school }\end{array}$ & $\begin{array}{r}0.849 \\
(0.109) \\
\text { ref. }\end{array}$ & $\begin{array}{r}0.878 \\
(0.0960) \\
\text { ref. }\end{array}$ & $\begin{array}{r}1.422^{* * *} \\
(0.227) \\
\text { ref. }\end{array}$ & $\begin{array}{r}1.905 * * * \\
(0.378) \\
\text { ref. }\end{array}$ & $\begin{array}{r}0.866 \\
(0.114) \\
\text { ref. }\end{array}$ & $\begin{array}{r}0.864 \\
(0.0979) \\
\text { ref. }\end{array}$ & $\begin{array}{r}1.419 * * \\
(0.239) \\
\text { ref. }\end{array}$ & $\begin{array}{r}2.020 * * * \\
(0.445) \\
\text { ref. }\end{array}$ & $\begin{array}{r}0.856 \\
(0.115) \\
\text { ref. }\end{array}$ & $\begin{array}{c}0.855 \\
(0.0979) \\
\text { ref. }\end{array}$ & $\begin{array}{c}1.402 * * \\
(0.238) \\
\text { ref. }\end{array}$ & $\begin{array}{c}1.997 * * * \\
(0.443) \\
\text { ref. }\end{array}$ \\
\hline Junior college & $\begin{array}{r}1.030 \\
(0.128)\end{array}$ & & & & $\begin{array}{r}0.998 \\
(0.123)\end{array}$ & & & & $\begin{array}{r}1.008 \\
(0.126)\end{array}$ & & & \\
\hline $\begin{array}{l}\text { Bachelor } \\
\text { Graduate }\end{array}$ & $\begin{array}{r}1.826 * * * \\
(0.225) \\
2.526 * * * \\
(0.440) \\
\end{array}$ & $\begin{array}{r}1.509 * * * \\
(0.162) \\
2.001 * * * \\
(0.275) \\
\end{array}$ & $\begin{array}{r}1.290 * * \\
(0.165) \\
2.092 * * * \\
(0.370) \\
\end{array}$ & $\begin{array}{r}0.816 \\
(0.209) \\
0.839 \\
(0.239) \\
\end{array}$ & $\begin{array}{r}1.725^{* * *} \\
(0.217) \\
2.309 * * * \\
(0.403) \\
\end{array}$ & $\begin{array}{r}1.465 * * * \\
(0.159) \\
1.869 * * * \\
(0.256) \\
\end{array}$ & $\begin{array}{r}1.239 * \\
(0.160) \\
1.895^{* * * *} \\
(0.340) \\
\end{array}$ & $\begin{array}{r}0.795 \\
(0.216) \\
0.729 \\
(0.207) \\
\end{array}$ & $\begin{array}{r}1.734 * * * * \\
(0.217) \\
2.346 * * * \\
(0.409) \\
\end{array}$ & $\begin{array}{c}1.471 * * * \\
(0.161) \\
1.892 * * * \\
(0.261) \\
\end{array}$ & $\begin{array}{c}1.240^{*} \\
(0.162) \\
1.893^{* * *} \\
(0.341) \\
\end{array}$ & $\begin{array}{c}0.793 \\
(0.216) \\
0.725 \\
(0.206) \\
\end{array}$ \\
\hline
\end{tabular}




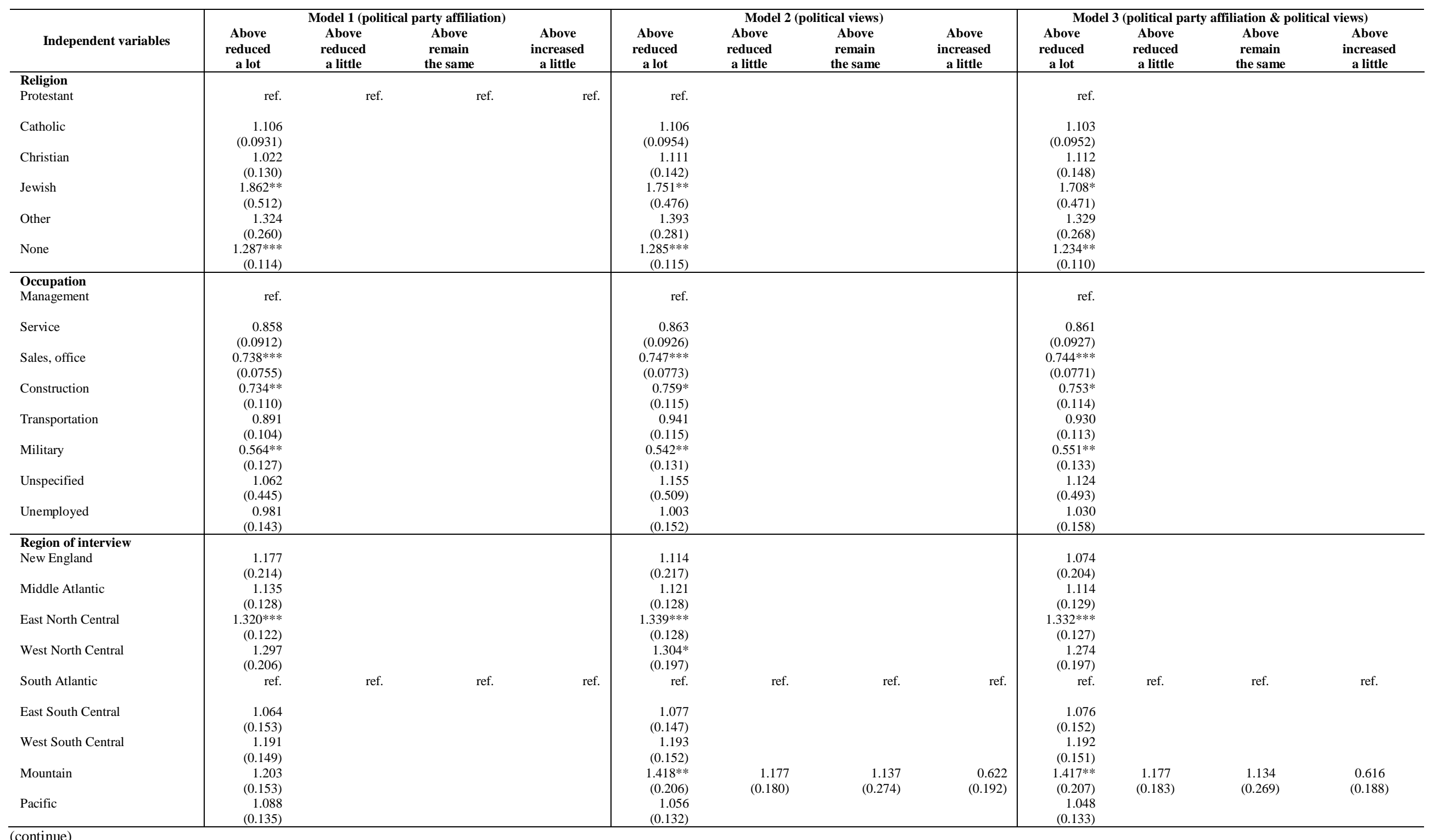




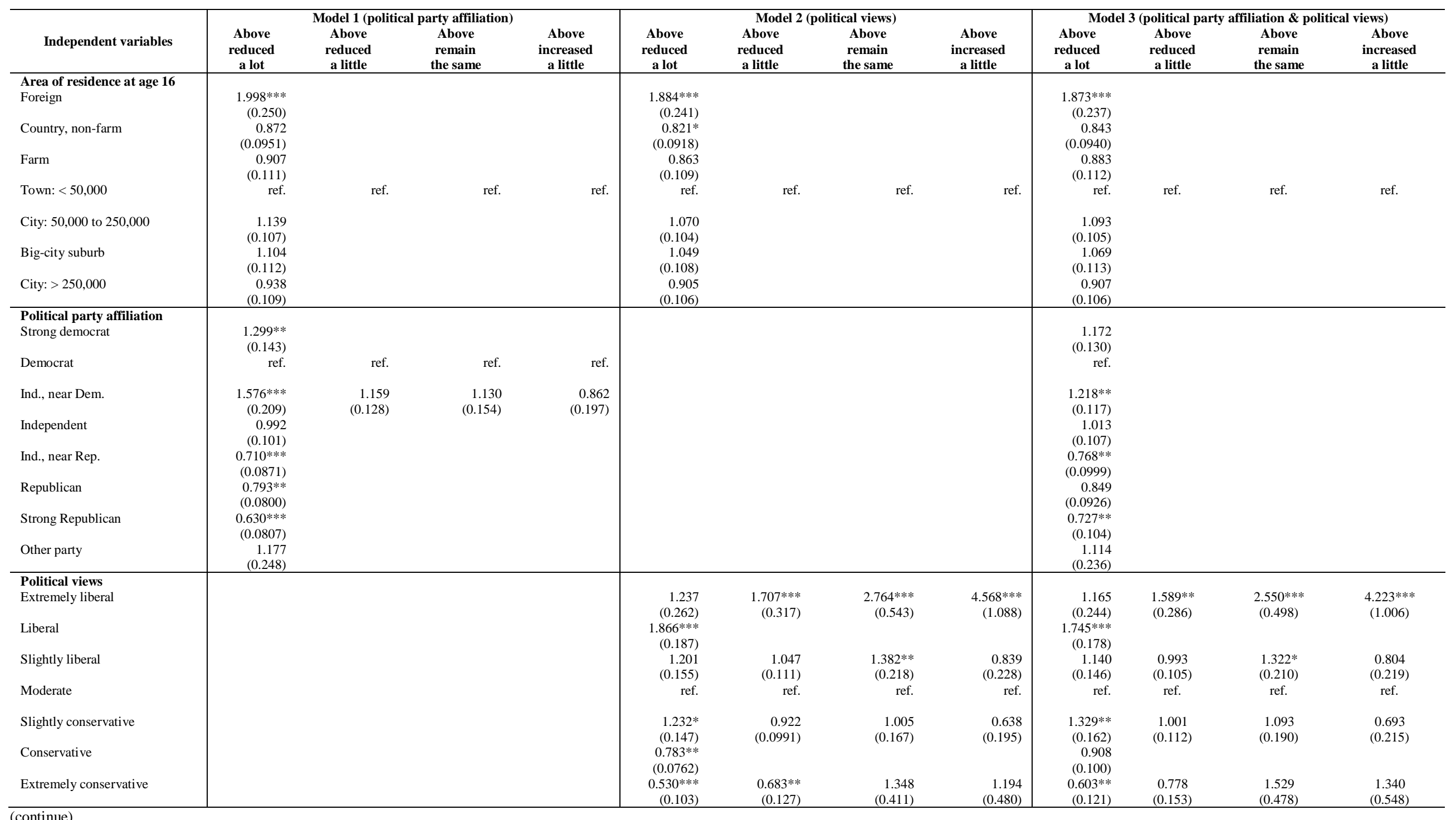




\begin{tabular}{|c|c|c|c|c|c|c|c|c|c|c|c|c|}
\hline \multirow[b]{2}{*}{ Independent variables } & \multicolumn{4}{|c|}{ Model 1 (political party affiliation) } & \multicolumn{4}{|c|}{ Model 2 (political views) } & \multicolumn{4}{|c|}{ Model 3 (political party affiliation \& political views) } \\
\hline & $\begin{array}{c}\text { Above } \\
\text { reduced } \\
\text { a lot }\end{array}$ & $\begin{array}{l}\text { Above } \\
\text { reduced } \\
\text { a little }\end{array}$ & $\begin{array}{l}\text { Above } \\
\text { remain } \\
\text { the same }\end{array}$ & $\begin{array}{c}\text { Above } \\
\text { increased } \\
\text { a little }\end{array}$ & $\begin{array}{c}\text { Above } \\
\text { reduced } \\
\text { a lot }\end{array}$ & $\begin{array}{l}\text { Above } \\
\text { reduced } \\
\text { a little }\end{array}$ & $\begin{array}{l}\text { Above } \\
\text { remain } \\
\text { the same }\end{array}$ & $\begin{array}{c}\text { Above } \\
\text { increased } \\
\text { a little }\end{array}$ & $\begin{array}{c}\text { Above } \\
\text { reduced } \\
\text { a lot }\end{array}$ & $\begin{array}{c}\text { Above } \\
\text { reduced } \\
\text { a little }\end{array}$ & $\begin{array}{l}\text { Above } \\
\text { remain } \\
\text { the same }\end{array}$ & $\begin{array}{c}\text { Above } \\
\text { increased } \\
\text { a little }\end{array}$ \\
\hline Prop. of unemployment & $\begin{array}{r}0.790 \\
(0.156)\end{array}$ & & & & $\begin{array}{r}0.816 \\
(0.155)\end{array}$ & & & & $\begin{array}{r}0.796 \\
(0.151)\end{array}$ & & & \\
\hline Prop. of college graduates & $\begin{array}{l}1.407^{*} \\
(0.270)\end{array}$ & & & & $\begin{array}{r}1.368 \\
(0.265)\end{array}$ & & & & $\begin{array}{l}1.416^{*} \\
(0.276) \\
\end{array}$ & & & \\
\hline Prop. of Protestants/Catholics & $\begin{array}{r}0.710 \\
(0.175) \\
\end{array}$ & & & & $\begin{array}{r}0.712 \\
(0.182) \\
\end{array}$ & & & & $\begin{array}{r}0.720 \\
(0.185) \\
\end{array}$ & & & \\
\hline Prop. of immigrants & $\begin{array}{l}2.187^{*} \\
(0.947) \\
\end{array}$ & & & & $\begin{array}{r}2.454 * * * \\
(1.112) \\
\end{array}$ & & & & $\begin{array}{r}2.340^{*} \\
(1.050)\end{array}$ & & & \\
\hline Constant & $\begin{array}{r}2.349 * * * * \\
(0.656) \\
\end{array}$ & $\begin{array}{r}0.704 \\
(0.194) \\
\end{array}$ & $\begin{array}{r}0.0807 * * * * \\
(0.0241) \\
\end{array}$ & $\begin{array}{r}0.0198 * * * \\
(0.00642) \\
\end{array}$ & $\begin{array}{r}2.239^{* * * *} \\
(0.646) \\
\end{array}$ & $\begin{array}{r}0.674 \\
(0.189) \\
\end{array}$ & $\begin{array}{r}0.0704^{* * * *} \\
(0.0215) \\
\end{array}$ & $\begin{array}{r}0.0181 * * * \\
(0.00610) \\
\end{array}$ & $\begin{array}{r}2.253^{* * * *} \\
(0.664) \\
\end{array}$ & $\begin{array}{c}0.673 \\
(0.192) \\
\end{array}$ & $\begin{array}{c}0.0697 * * * \\
(0.0219) \\
\end{array}$ & $\begin{array}{c}0.0178^{* * * *} \\
(0.00619) \\
\end{array}$ \\
\hline Observations & 5,237 & 5,237 & 5,237 & 5,237 & 5,075 & 5,075 & 5,075 & 5,075 & 5,075 & 5,075 & 5,075 & 5,075 \\
\hline
\end{tabular}

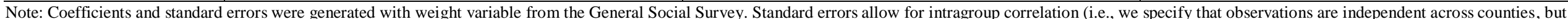

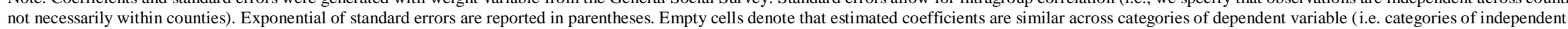
variables do not violate the proportional odds/parallel lines assumption). $* * *$ Significant at $\mathrm{p}<0.01, * *$ Significant at $\mathrm{p}<0.05,{ }^{*}$ Significant at $\mathrm{p}<0.1$

Source: 2008, 2010, 2012, and 2014 General Social Surveys and American Community Surveys five-year estimates. 


\section{References}

Beaghen, Michael, and Lynn Weidman. 2008. Statistical isues of interpretation of the American Community Survey's one-, three-, and five-year period estimates. Washington, DC: U.S. Census Bureau.

Berg, J. A. 2015. "Explaining Attitudes toward Immigrants and Immigration Policy: A Review of the Theoretical Literature." Sociology Compass 9 (1):23-34. doi: 10.1111/soc4.12235.

Berg, Justin Allen. 2010. "Race, Class, Gender, and Social Space: Using an Intersectional Approach to Study Immigration Attitudes." The Sociological Quarterly (2):278.

Blalock, Hubert M. 1970. Toward a theory of minority-group relations. Capricorn books ed. [by] Hubert M. Blalock, Jr: New York : Capricorn Books, [1970]. Capricorn books ed. Bibliographies, Non-fiction.

Bobo, L., and F. Licari. 1989. "Education and political tolerance: Testing the effects of cognitive sophistication and target group affect." Public Opinion Quarterly 53 (3):285-308. doi: $10.1086 / 269154$.

Burns, Peter, and James G. Gimpel. 2000. "Economic Insecurity, Prejudicial Stereotypes, and Public Opinion on Immigration Policy." Political Science Quarterly (2):201. doi: 10.2307/2657900.

Chandler, Charles R., and Yung-mei Tsai. 2001. "Social factors influencing immigration attitudes: an analysis of data from the General Social Survey." The Social Science Journal 38:177-188. doi: 10.1016/S0362-3319(01)00106-9.

Cote, R. R., and B. H. Erickson. 2009. "Untangling the Roots of Tolerance How Forms of Social Capital Shape Attitudes Toward Ethnic Minorities and Immigrants." American Behavioral Scientist 52 (12):1664-1689. doi: 10.1177/0002764209331532.

Dixon, Jeffrey C. 2006. "The Ties That Bind and Those That Don't: Toward Reconciling Group Threat and Contact Theories of Prejudice." Social Forces (4):2179. 
Ellison, C. G., and M. A. Musick. 1993. "Southern Intolerance: A fundamentalist effect." Social Forces 72 (2):379-398. doi: 10.2307/2579853.

Espenshade, Thomas, and Katherine Hempstead. 1996. "Contemporary American Attitudes Toward U.S. Immigration." $30(2): 535-570$.

Espenshade, Thomas J. 1995. "Unauthorized Immigration to the United States." Annual Review of Sociology:195.

Esses, V. M., and J. F. Dovidio. 2011. "Social Psychology, Social Issues, and Social Policy: What Have We Learned?" Social Issues and Policy Review 5 (1):1-7. doi: 10.1111/j.17512409.2011.01023.x.

Fetzer, Joel S. 2000. Public attitudes toward immigration in the United States, France, and Germany. Joel S. Fetzer: Cambridge ; New York : Cambridge University Press, 2000.

Bibliographies, Non-fiction.

Fussell, E. 2014. "Warmth of the Welcome: Attitudes Toward Immigrants and Immigration Policy in the United States." In Annual Review of Sociology, Vol 40, edited by K. S. Cook and D. S. Massey, 479-498. Palo Alto: Annual Reviews.

Haubert, Jeannie, and Elizabeth Fussell. 2006. "Explaining Pro-Immigrant Sentiment in the U.S.: Social Class, Cosmopolitanism, and Perceptions of Immigrants." International Migration Review 40 (3):489-507.

Hood III, M. V., and Irwin L. Morris. 1997. ¿¿Amigo o Enemigo?: Context, Attitudes, and Anglo Public Opinion toward Immigration." Social Science Quarterly (2):309.

Jackman, Mary R., and Michael J. Muha. 1984. "Education and Intergroup Attitudes: Moral Enlightenment, Superficial Democratic Commitment, or Ideological Refinement?" American Sociological Review (6):751.

Janus, Alexander L. 2010. "The Influence of Social Desirability Pressures on Expressed Immigration Attitudes." Social Science Quarterly (4):928. 
Long, J. Scott, and Jeremy Freese. 2014. Regression Models for Categorical Dependent Variables Using Stata. 3 ed. College Station: Stata Press.

Manson, Steven, Jonathan Schroeder, David Van Riper, and Steven Ruggles. 2018. IPUMS National Historical Geographic Information System: Version 13.0 [Database]. Minneapolis: University of Minnesota.

McLaren, Lauren M. 2003. "Anti-Immigrant Prejudice in Europe: Contact, Threat Perception, and Preferences for the Exclusion of Migrants." Social Forces (3):909.

Miller, Steven V. 2018. Clemson.

Moore, L. M., and S. Ovadia. 2006. "Accounting for spatial variation in tolerance: The effects of education and religion." Social Forces 84 (4):2205-2222. doi: 10.1353/sof.2006.0101.

Neiman, M., M. Johnson, and S. Bowler. 2006. "Partisanship and views about immigration in Southern California: Just how partisan is the issue of immigration?" International Migration 44 (2):3556. doi: 10.1111/j.1468-2435.2006.00363.x.

Ross, A. D., and S. M. Rouse. 2015. "Economic Uncertainty, Job Threat, and the Resiliency of the Millennial Generation's Attitudes Toward Immigration." Social Science Quarterly 96 (5):13631379. doi: $10.1111 /$ ssqu. 12168 .

Sanchez, Gabriel R. 2006. "The Role of Group Consciousness in Political Participation Among Latinos in the United States." American Politics Research 34 (4):427-450. doi: $10.1177 / 1532673 \times 05284417$.

Sanchez, Gabriel R. 2008. "Latino Group Consciousness and Perceptions of Commonality with African Americans." Social Science Quarterly (2):428.

Stets, Jan E., and Peter J. Burke. 2000. "Identity Theory and Social Identity Theory." Social Psychology Quarterly (3):224. 
Williams, Richard. 2016. "Understanding and interpreting generalized ordered logit models." The Journal of Mathematical Sociology 40 (1):7-20. doi:

http://dx.doi.org/10.1080/0022250X.2015.1112384. 